\title{
A EVOLUÇÃO DOS PREÇOS DA TERRA NO ESTADO DE SÃO PAULO: ANÁLISE DE SEUS DETERMINANTES
}

\author{
CLEA SANTOS RAHAL
}

Dissertação apresentada à Escola Superior de Agricultura "Luiz De Queiroz", Universidade de São Paulo, para obtenção do título de Mestre em Ciências, Área de Concentração: Economia Aplicada

P I R A C I C A B A

Estado de São Paulo - Brasil

Março - 2003 


\title{
A EVOLUÇÃO DOS PREÇOS DA TERRA NO ESTADO DE SÃO PAULO: ANÁLISE DE SEUS DETERMINANTES
}

\author{
CLEA SANTOS RAHAL
}

Engenheiro Agrônomo

Orientador: Prof. Dr. ALEXANDRE LAHÓZ MENDONÇA DE BARROS

Dissertação apresentada à Escola Superior de Agricultura "Luiz De Queiroz", Universidade de São Paulo, para obtenção do título de Mestre em Ciências, Área de Concentração: Economia Aplicada

P I R A C I C A B A

Estado de São Paulo - Brasil

Março - 2003 
Dados Internacionais de Catalogação na Publicação (CIP)

DIVISÃO DE BIBLIOTECA E DOCUMENTAÇÃO - ESALQ/USP

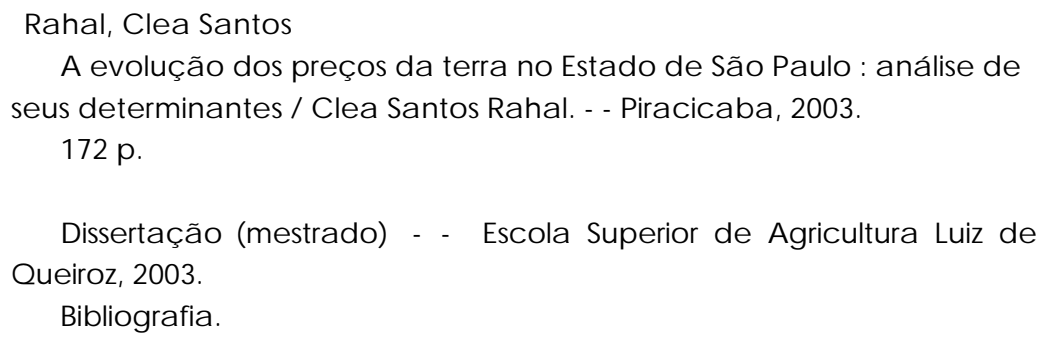

1. Arrendamento 2. Econometria 3. Polític a agrícola 4. Preço 5. Uso do so (Economia) I. Título

CDD 333.7313

\section{"Permitida a cópia total ou parcial deste documento, desde que citada a fonte - $O$ autor"}


À minha mãe Maria Stela e à minha irmã Lilian 


\section{AGRADECIMENTOS}

É muito difícil agradecer a tantas pessoas em tão pouco espaço. Ter chegado até esta etapa demandou inúmeros esforços e, portanto, tento agradecer aqui a algumas dessas pessoas.

Ao meu orientador, o prof. Alexandre Lahóz Mendonça de Barros, que, com muita sutileza, me ensinou a aprender. Obrigada por sua paciência, seu dinamismo e sua disposição. Ao professor Alexandre, um agradecimento especial pela emoção com que passa os ensinamentos em suas aulas, emoção essa que contagia a todos e que exalta a economia como bela ciência que é. Grande conhecedor e apaixonado pela teoria do crescimento econômico, meu profundo respeito a esse professor que faz da ciência econômica uma arte.

Ao prof. Joaquim Bento de Souza Ferreira Filho, quem me instigou a estudar a oscilação dos preços da terra e quem me orientou na fase inicial deste estudo. Muito obrigada por todo o incentivo.

Aos professores Evaristo Marzabal Neves, José Vicente Caixeta Filho e Rodolfo Hoffmann, pelas sugestões, críticas e atenta leitura que fizeram desse trabalho na etapa da qualificação.

À professora Miriam Bacchi, que sempre com muita paciência e disposição solucionou minhas inúmeras dúvidas sobre econometria de séries de tempo.

Aos professores Alexandre Lahóz Mendonça de Barros, Evaristo Marzabal Neves, Joaquim Bento de Souza Ferreira Filho e José Vicente Caixeta Filho pela convivência no período da graduação. A conduta profissional de vocês foi a 
inspiração que me conduziu a este caminho.A todos os demais professores do departamento de Economia, Administração e Sociologia, pelo aprendizado que com eles adquiri.

Aos funcionários não-docentes do departamento, em especial, à Maielli, que acolhe a todos nós, pós-graduandos, como filhos. Aos funcionários da biblioteca de economia, Ligiana e Álvaro, por todo o auxílio na consulta bibliográfica e na normatização do trabalho.

Aos meus queridos amigos de Araçatuba que, embora vivendo longe, nunca estiveram distantes: Caru, Alemão, Keila, Galetti, Lucila, Liana e Paulão.

A alguns dos amigos que fiz em Piracicaba, uns mestrandos, outros já mestres: Alex, Bel, Capricho, Cupim, Deu-Baxa, Raquel e Térsia.

Ao Fábio Lagazzi, pela paciência e companheirismo em uma das fases mais difíceis do mestrado. E à sua família, por ser adorável.

Agradeço imensamente aos colegas Lucílio Alves e Marcos Hasegawa por toda a atenção e paciência no auxílio à parte econométrica do trabalho, assim como pela bibliografia cedida. Sem a colaboração dos dois, o trabalho teria sido muito mais lento e exaustivo. Agradeço também ao Elisson pela ajuda na formatação.

Minha gratidão a todos os colegas de turma do mestrado, aqueles que me ajudaram a, repentinamente, pensar não somente como engenheira agrônoma, mas também como economista. Gostaria de agradecer especialmente aos colegas: Ariel, Maria do Carmo, Rodrigo, Rogério e Roberto.

À minha querida amiga e também colega de turma do mestrado, Roberta, um agradecimento mais que especial. Com ela compartilhei a casa, os estudos, as tensões, os segredos, os sonhos e os inúmeros momentos de alegria. Hoje, compartilhamos a saudade desses momentos e a certeza de uma amizade sem fim.

A todos os colegas de pós-graduação, por tornarem meus dias no mestrado cada vez mais agradáveis. 
Aos meus queridos tios e primos que, de uma forma ou de outra, sempre estiveram presentes em minha vida. Um agradecimento especial à minha tia Ana Maria, quem me apresentou a esta Escola e à Piracicaba que eu adoro tanto.

À minha irmã Lilian e ao meu cunhado Carlos, pelo incentivo ao estudo, pela preocupação e pelo exemplo. Ao meu sobrinho querido que ainda nem nasceu e já traz tantas alegrias.

Ao meu pai e irmãos que não estão mais aqui, por deixarem viva a imagem de como é belo e importante ter uma família. Ao meu pai, em especial, pelos valores que nos passou, dentre os quais está a educação e a importância do estudo.

Por fim, gostaria de agradecer à minha mãe Maria Stela que, pelo destino, passou a ter uma forte ligação com a agricultura e, conseqüentemente, com a terra (como fator de produção!). Obrigada, mamãe. Este trabalho é o mínimo com que lhe devo retribuir pelo incentivo, preocupação e por toda uma vida de dedicação intensa. 


\section{SUMÁRIO}

Página

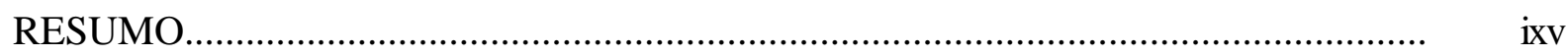

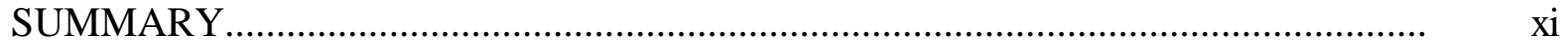

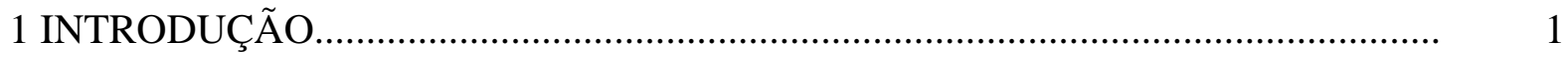

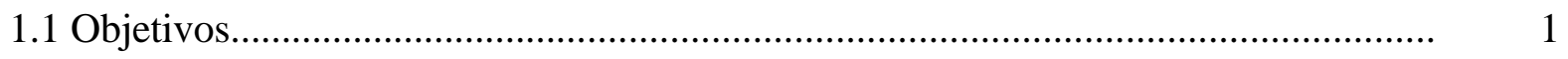

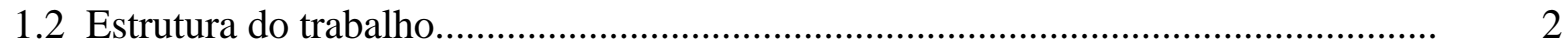

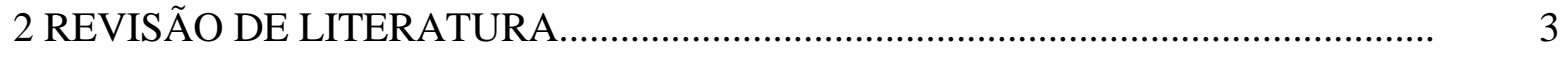

2.1 Definição do problema.................................................................................... 4

2.2 Os diversos enfoques sobre os determinantes dos preços da terra............................ 7

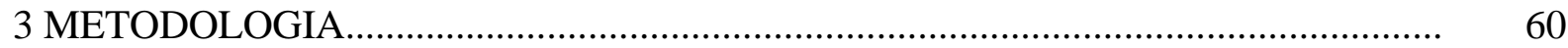

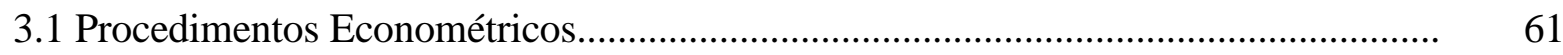

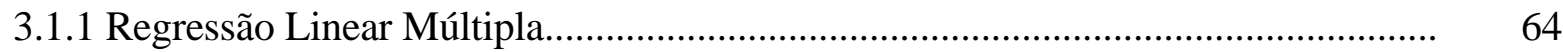

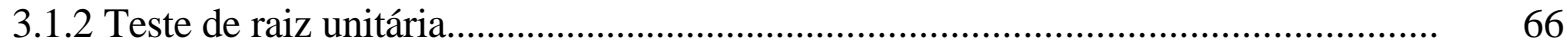

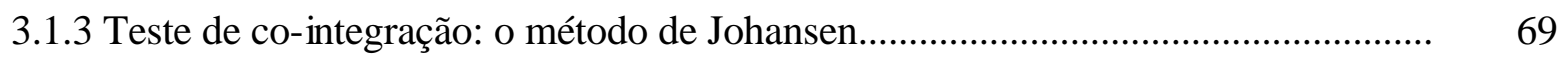

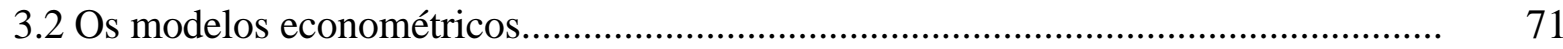

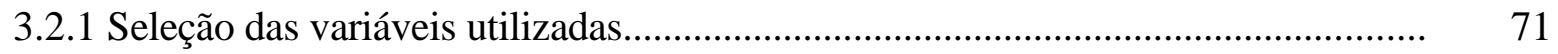

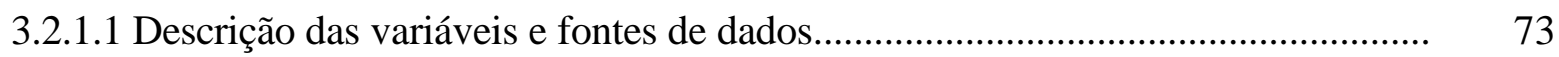

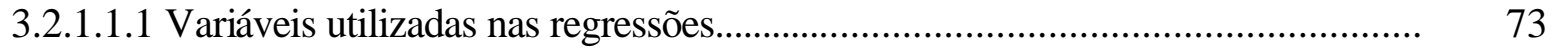

3.2.1.1.2 Variáveis utilizadas nos testes de raiz unitária e co-integração......................... 81

3.2.1.2 Hipóteses subjacentes às variáveis selecionadas............................................. 84

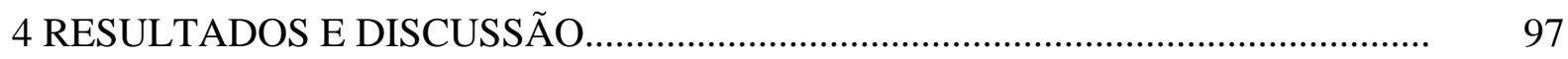

4.1 Resultados obtidos das regressões dos preços de venda das terras de cultura de

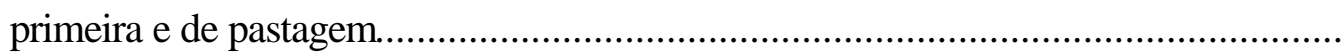


4.2 Resultados obtidos das regressões para os valores de arrendamento de terras para culturas e de aluguel de pasto para animais............................................................ 115

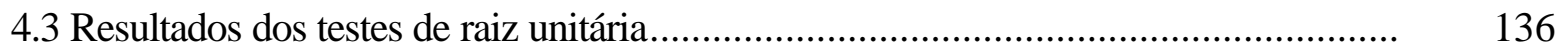

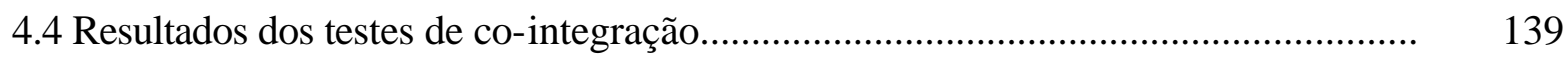

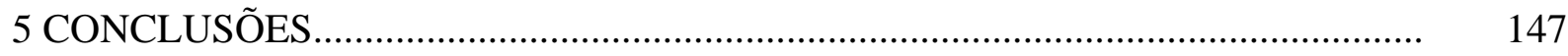

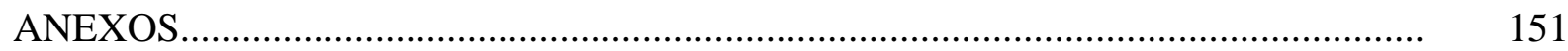

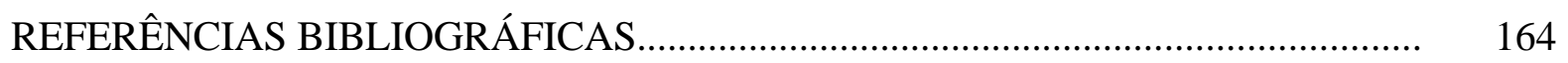

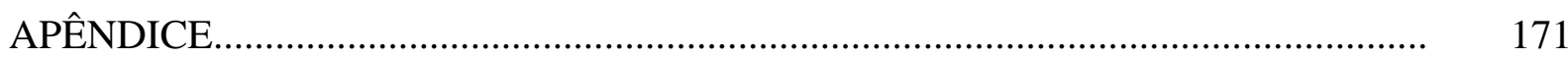




\title{
A EVOLUÇÃO DOS PREÇOS DA TERRA NO ESTADO DE SÃO PAULO: ANÁLISE DE SEUS DETERMINANTES
}

\author{
Autora: CLEA SANTOS RAHAL \\ Orientador: Prof. ALEXANDRE LAHÓZ MENDONÇA DE BARROS
}

\section{RESUMO}

Este trabalho tem o intuito de analisar quais foram os determinantes dos preços de venda e de arrendamento da terra de cultura de primeira e de pastagem no estado de São Paulo, de 1969 a 2001. Além disso, procura-se mostrar que os preços de venda da terra de diferentes categorias e em diferentes estados estão relacionados. Conforme a teoria econômica, o preço da terra deveria refletir o fluxo de receitas que essa terra pode gerar, descontado a uma determinada taxa de juro. Contudo, a literatura argumenta que em diversos momentos na economia brasileira, especialmente nas décadas de 70, 80 e início de 90, os determinantes do preço da terra foram além da taxa de juro e do fluxo de receitas gerado pelo ativo. A determinação do preço da terra contemplou também variáveis indiretamente relacionadas ao processo produtivo, como o nível de atividade econômica e a taxa de inflação. Tendo sido analisadas as diversas eferências sobre os determinantes dos preços da terra, foram selecionadas variáveis de interesse micro e macroeconômico para compor os modelos econométricos de determinação dos preços de terra de cultura de primeira, terra de pastagem, arrendamento para culturas e aluguel de pasto para animais. A ferramenta econométrica utilizada foi a regressão linear múltipla. As variáveis selecionadas que estão diretamente ligadas ao setor agrícola foram: poder de compra do agricultor, índice de paridade, índices de preços recebidos e de preços 
pagos pelos produtores e volume de subsídio concedido através do crédito rural. A fim de representar o ambiente macroeconômico, foram estimadas: a taxa de inflação anual vigente no período, uma proxy para o hiato do produto, taxa de juro e infra-estrutura governamental (representada pela extensão total das rodovias pavimentadas e não pavimentadas do estado de São Paulo). Construiu-se ainda uma variável binária com o intuito de verificar se houve um deslocamento significativo no nível de preços de venda e de arrendamento de terra de cultura e de pastagem, no período de 1973 a 1994. Procurou-se ainda verificar se existe relação entre os preços de venda da terra de diferentes categorias, dentro do estado de São Paulo e de algumas categorias deste estado com outras do Centro-Sul do país. Para tanto foram utilizados os testes econométricos de raiz unitária (metodologia proposta por Dickey e Fuller) e de cointegração (segundo a metodologia proposta por Johansen). Dos resultados obtidos, constata-se a que tanto os preços da venda de terra como os preços de arrendamento (para cultura e para pastagem) foram mais elásticos às variáveis relacionadas à atividade agrícola (poder de compra, termos de troca, etc) em detrimento das variáveis macroeconômicas e do crédito rural. Ressalta-se ainda que a variável binária foi significativa nos modelos de determinação dos preços de venda de terra para culturas, para pastagem e também nos de arrendamento, para as duas categorias em questão. Os resultados dos testes de raiz unitária e de co-integração suportaram as evidências empíricas de que os preços de diferentes tipos de terra, em diferentes regiões, estão relacionados. A explanação destes resultados emerge de dois lados: da demanda por terras com a finalidade agrícola e da demanda por terras para fins especulativos. Esses resultados estão de acordo com algumas das diversas referências sobre os determinantes dos preços da terra analisadas. 


\title{
LAND PRICES EVOLUTION IN SAO PAULO STATE: ANALYSIS OF ITS DETERMINANTS
}

\author{
Author: CLEA SANTOS RAHAL \\ Adviser: Prof. ALEXANDRE LAHÓZ MENDONÇA DE BARROS
}

\section{SUMMARY}

This dissertation has the intention to determine the price of land (for both crop and pasture land), land rent (again for crop and pasture land), in Sao Paulo State, from 1969 to 2001. Besides that, it has the intention of showing that prices of different categories and of different States are related. According to the economic theory, land price should be the income present value calculated, considering a specific interest rate. However, literature has shown that in different moments in the Brazilian economy, especially in the 70ies, 80ies and early 90ies, there were other determinants of land price, apart from income and interest rate. Land price is also determined by others indirect variables, such as economic activity and inflation. The study has selected several variables (micro and macroeconomics) to determine its relevance in explaining crop and pasture land prices and rents. The econometrical tool used was multiple linear regression. Variables related to agriculture were: purchasing power, terms of trade, product and factor prices (index), and governmental loan subsidies. In order to represent macroeconomic variables, the work has chosen four different determinants: inflation rate, infrastructure (roads), interest rate and GDP gap. A dummy variable was taken to verify whether crop and pasture land prices have changed significantly over 1973 to 1994. Another objective considered was to verify crop and pasture land long run relation 
between Sao Paulo State and eight different States. The study also analyses long run relation among prices of four different land categories. To do so, it used unit root tests (proposed by Dickey and Fuller) and cointegration tests (according to Johansen's methodology). Results have shown that land price and rent are more elastic to agricultural related variables (purchasing power, terms of trade, etc). Although it has been determined that variables affects land prices and rent, its effects are much lower than agricultural ones. The dummy variable has shown to be statistically significant in several models. Unit root and cointegration tests supported empirical evidences that different kind of land price have similar pattern of movement. Also, same kind if land have similar behavior among different states. These results are due to factors related to land demand for agriculture and land demand for speculative purposes. Results supported evidences raised by several researchers surveyed in this study. 


\section{INTRODUÇÃO}

A evolução dos preços da terra e, principalmente, os fatores que determinam a sua formação têm sido objeto de análise de muitos estudiosos, em função dos aspectos teóricos e empíricos envolvidos. Especialmente em economias com elevadas taxas de inflação, como as observadas na economia brasileira até meados da década passada, o valor da terra sempre incorporou elementos de reserva de valor, além de meramente ativo de produção. Com isto, a análise do processo de formação de seu preço precisa ser ampliada para além do valor presente do fluxo de retornos descontado, associado ao ativo.

\subsection{Objetivos}

O presente estudo tem o objetivo de analisar a evolução dos preços de venda da terra rural e de arrendamentos (categorias lavoura e pastagem) no estado de São Paulo, no período de 1969 a 2001.

Pretende-se também observar se existe uma relação de equilíbrio estável de longo prazo entre os preços dos diferentes tipos de terra, no estado de São Paulo. De maneira semelhante, busca-se verificar a existência de tal equilíbrio entre os preços de venda de terra de lavoura e pastagem em São Paulo e em alguns estados do Centro-Sul do país.

Para analisar a evolução dos preços de venda de terra rural e de arrendamento no estado de São Paulo, foi utilizada a ferramenta econométrica regressão linear 
múltipla, buscando, dessa maneira, identificar os principais fatores determinantes desses preços no período em questão.

Ao testar a existência de relação de longo prazo entre os diferentes tipos de terra no estado de São Paulo e entre os preços de venda de terra de lavoura e pastagem em São Paulo e estados do Centro-Sul utilizou-se a técnica da co-integração.

\subsection{Estrutura do trabalho}

$\mathrm{Na}$ primeira parte do trabalho, descreve-se o problema em questão, apontando os fatores que obtiveram maior ênfase na literatura como elementos explicativos dos preços de venda e aluguel da terra.

Em seguida, discute-se a metodologia empregada no estudo da análise dos determinantes dos preços de venda da terra de cultura de primeira, preços de venda da terra de pastagem, valor do arrendamento para culturas e aluguel de pasto. Prosseguindo, apresenta-se a metodologia utilizada para se obter as relações de longo prazo entre os preços de venda da terra de cultura e de pecuária no estado de São Paulo e preços de venda de terra de lavoura e terra para pecuária em outros estados do Centro-Sul do país. Ainda nesse capítulo, apresentam-se todas as variáveis utilizadas na pesquisa, seus procedimentos de estimação e as expectativas quanto ao comportamento de cada uma delas no trabalho.

$\mathrm{Na}$ terceira parte são discutidos os resultados obtidos e suas implicações, comparando-os com aqueles obtidos na literatura.

A última parte corresponde às conclusões do trabalho. 


\section{REVISÃO DE LITERATURA}

O mercado de terra apresentou-se muito instável desde 1966 até 1995, fato esse que despertou a curiosidade de muitos pesquisadores sobre o tema em questão.

Existe uma certa dificuldade em agrupar-se com precisão os vários enfoques observados na literatura. Entretanto, pode-se tentar alguma separação, dado que alguns autores privilegiaram certas teorias ou observaram a predominância de alguma particularidade em seus estudos.

A primeira teoria seria aquela cuja maior importância é dada aos fatores inerentes ao próprio setor agrícola. Para os autores que defendem essa corrente, a demanda agrícola, a lucratividade da atividade e outros fatores ligados ao setor são aqueles que determinariam o preço da terra. Ressalta-se, todavia, que não há incompatibilidade das demais correntes com este tipo de abordagem.

Em uma segunda corrente, explicando as variações de preço da terra impulsionadas por fatores indiretamente ligados à atividade agrícola estão os autores que discutiram as relações entre preço da terra, crédito subsidiado e concentração fundiária.

O terceiro grupo de autores relacionou as flutuações dos preços da terra com variáveis de interesse econômico. De um lado existe o argumento de que a terra possui rentabilidade praticamente constante, o que a torna um ativo desejado durante as fases de queda da atividade econômica. Do outro, há um argumento próximo, porém distinto, de que a terra serviria como reserva de valor em qualquer estágio do ciclo econômico. 
Este capítulo detalha, inicialmente, o problema em questão. Em seguida, há a revisão dos principais estudos feitos sobre o mercado de terra no Brasil e em outros países, com ênfase nos determinantes dos preços de venda e de arrendamento da terra.

\subsection{Definição do problema}

Segundo a teoria econômica, o preço da terra deve refletir o valor presente dos fluxos de receitas que este fator pode gerar. Se assim fosse, o preço de venda da terra deveria refletir o valor de seu arrendamento. Johnson (1950), Chryst (1965), Reinsel e Reinsel (1979) e Doll (1983) são alguns dos autores que defendem essa definição.

Johnson (1950) analisou a reação do produto agregado da economia sob dois aspectos: queda dos preços relativos sob condições de depressão econômica (de 192933, nos EUA) e mudança nos preços relativos quando os recursos são plenamente empregados. Dentro desse contexto, pesquisou os motivos pelos quais o produto agrícola não caiu, assim como ocorreu com o produto dos demais setores durante a fase de depressão.

Sabe-se que a produção agrícola responde muito pouco a mudanças nos preços do produto agrícola, ou seja, a oferta de produtos agrícolas possui baixa elasticidade preço, pelo menos em um curto período de tempo (um ano, por exemplo). Porém, para Johnson (1950), a falta de reação da oferta do produto agrícola perante a depressão não esteve associada ao mercado de produto, mas sim à manutenção da plena utilização dos fatores produtivos.

O autor notou que a função de oferta da terra, fator produtivo de interesse nesse trabalho, é inelástica, enquanto que seus preços são muito flexíveis. Com a queda nos preços dos produtos agrícolas, a terra continua sendo utilizada plena e intensivamente enquanto que seu preço cai demasiadamente (graças à característica de sua função oferta inelástica). Para um fator de produção com oferta elástica, uma redução do preço do produto agrícola levaria à queda na utilização do bem produtivo. Entretanto, como a terra não possui esta última característica, com a redução do preço do produto agrícola o 
ajuste no mercado de terras se dá com a queda mais que proporcional no preço do arrendamento $^{1}$ (mais do que a queda na demanda). Assim, há a equalização entre oferta e demanda desse fator fazendo com que ele seja utilizado plenamente.

O ajuste no mercado de terras se dá principalmente via preços e não via quantidade. Dessa maneira, seguindo o raciocínio de Johnson (1950), a queda do produto agregado da economia levaria à redução do preço do aluguel da terra em uma proporção maior que a queda na demanda pelo produto agrícola, porém com a manutenção da oferta agrícola.

Chryst (1965), em seu estudo sobre preço e renda da terra nos Estados Unidos, de 1952 a 1964, defendeu que os preços desse fator e sua renda estão intimamente relacionados. Para esse autor, embora o preço da terra possa, por diversos fatores, distanciar-se da renda agrícola, ele ainda deve refletir essa renda agrícola ou não agrícola que a terra possa gerar.

Reinsel e Reinsel (1979) ressaltaram em seu estudo o papel do valor presente dos fluxos de renda como principal elemento formador do preço da terra. A fórmula que determinaria o preço da terra, na opinião dos autores, seria:

$$
V=\frac{\sum a_{t}}{\left(1+i_{t}\right)^{t}}
$$

sendo $V$ o valor presente do ativo, $a$ o valor esperado do retorno no ano $t$ e $i$ a taxa de desconto no ano $t$.

Os autores também enfatizaram que as demais variáveis associadas ao preço da terra, tais como preço dos produtos e dos insumos agrícolas, taxa de inflação, crédito, taxas de juros, entre outras, estariam computadas no valor esperado do retorno anual.

\footnotetext{
${ }^{1}$ Entende-se por arrendamento o aluguel de terra a ser utilizado com finalidade definida previamente entre as partes envolvidas, e cujo pagamento pode ser em unidades monetárias ou em espécie de produto agrícola.
} 
De maneira semelhante, a taxa de desconto seria função da inflação, do risco e da preferência por dinheiro no tempo.

Nota-se, portanto, que, para Reinsel e Reinsel (1979), os determinantes do preço da terra estão associados principalmente aos fatores internos do setor agrícola.

Doll et al. (1983) realizaram um estudo sobre os fatores que influenciaram o valor da terra rural nos Estados Unidos. Realizaram testes econométricos buscando confirmar as hipóteses levantadas na literatura. Variáveis ligadas à agricultura (como produtividade e paridade do poder de compra), à economia (como taxa de juros) e variáveis relacionadas aos incentivos governamentais foram utilizadas na pesquisa. Os resultados obtidos não foram satisfatórios, embora os autores defendessem a teoria dos fatores inerentes à própria agricultura como sendo a principal responsável pela determinação do preço da terra.

Nota-se que no Brasil houve um descolamento entre os preços de venda da terra e de arrendamento, o que pode ser visto na Figura 1. Se os preços de venda da terra refletissem perfeitamente o valor do arrendamento, a relação entre estas variáveis deveria variar em proporção semelhante às variações da taxa de juro. Entretanto, os estudos existentes sobre os determinantes do preço da terra não confirmaram essa afirmativa. Em muitas pesquisas notou-se que os preços de venda da terra foram além do valor do arrendamento capitalizado. 


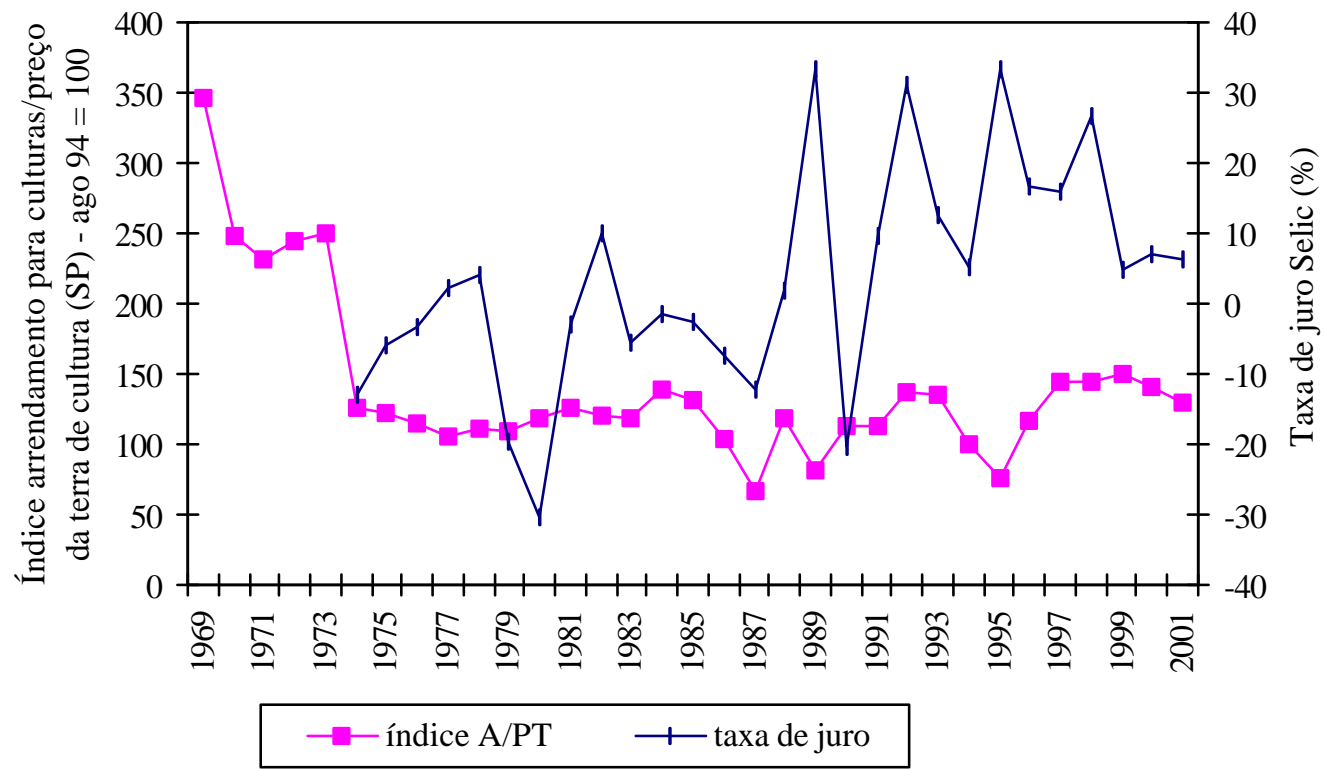

Figura 1 - Evolução do Índice arrendamento para culturas/preço de venda da terra de cultura de primeira no estado de São Paulo, 1969-2001 (base $1994=100$ ) e da taxa de juro real Selic (\%), de 1974 a 2001.

Fonte: Resultados da pesquisa.

Diversas variáveis externas ao setor agrícola ou indiretamente ligadas a ele construíram o cenário da economia brasileira nas últimas décadas. Variáveis macroeconômicas tais como hiato do produto e a instabilidade refletida na taxa de inflação foram alguns dos fatores que balizaram o comportamento de diversos setores, inclusive da agricultura. Isso tudo não passou despercebido pelos diversos autores que estudaram o mercado de terras agrícolas e que são mencionados a seguir.

\subsection{Os diversos enfoques sobre os determinantes dos preços da terra}

Oliveira e Costa (1977) formularam um modelo teórico na tentativa de enumerar as principais variáveis que explicaram a evolução dos preços de terra de pastagem e lavouras em 16 estados brasileiros ${ }^{2}$, no período de 1966 a 1974. A partir do

\footnotetext{
${ }^{2}$ RS, SC, PR, RJ, ES, MG, MT, GO, BA, SE, AL, PE, PB, RN, CE, MA.
} 
modelo teórico, esses autores estimaram um modelo reduzido de determinação do preço real do hectare de terra, utilizada para fins agrícolas. As variáveis explicativas do preço da terra selecionadas pelos autores foram: preços recebidos na agropecuária em termos reais, preços pagos por insumos em termos reais, infra-estrutura governamental, índice tecnológico e área agricultável total.

Os testes econométricos foram realizados em dois estágios. Primeiramente, Oliveira e Costa (1977) estimaram, através de série de tempo, o preço real por hectare de terra usada para fins agrícolas (lavoura e pastagem) em função das variáveis explicativas: preços recebidos na agropecuária em termos reais, preços pagos por insumos em termos reais e densidade viária ${ }^{3}$ - proxy para disponibilidade de infraestrutura governamental.

Numa segunda etapa, os autores estimaram três regressões, sendo a área agricultável total e o índice tecnológico as variáveis explicativas. Como variáveis dependentes utilizaram o preço por hectare de terra em lavoura, preço por hectare de terra em pastagem e preço por hectare de terra usada para fins agrícolas (média de lavouras e pastagens). As variáveis, nessa segunda etapa, foram testadas usando-se os dados em cross-section.

Como resultado da primeira parte, obtiveram valores positivos e significativos para o parâmetro dos preços recebidos pelos produtores, para a maioria dos estados, exceto para Rio Grande do Norte e Pernambuco. O parâmetro preço pago pelos insumos agrícolas, em geral, não foi significativo. Com relação à densidade viária, a partir dos

resultados obtidos, os estados puderam ser separados em três grupos: aqueles que obtiveram coeficiente positivo e significativo associado à variável; aqueles com

\footnotetext{
${ }^{3} G=\frac{R M+R E+R F}{A T E}$, em que

$G \quad=$ densidade viária;

$R M=$ mil quilômetros de rodovias municipais em $\mathrm{t}$;

$R E=$ mil quilômetros de rodovias estaduais em $\mathrm{t}$;

$R F=$ mil quilômetros de rodovias federais em $\mathrm{t}$;

$A T E$ = área terrestre do Estado i (em quilômetros quadrados)
} 
coeficiente negativo e significativo e aqueles com coeficiente não significativo (todos com $10 \%$ de significância).

Encontram-se no primeiro grupo os estados com baixo valor de densidade viária e também baixa ocupação de espaço econômico, tais como Mato Grosso e Maranhão. Assim, segundo os autores, a elevação na demanda por terra seguiu a rápida taxa de expansão da rede viária.

Rio Grande do Norte, Ceará, Pernambuco, Bahia e Goiás foram os principais representantes dos estados com coeficiente negativo e significativo para a densidade viária. Tais estados, coincidentemente, apresentaram valores intermediários para a densidade viária. Isso ocorreu, segundo argumento dos autores, porque a rápida expansão da rede viária provocou aumento na oferta de serviços da terra, sem a concomitante elevação na demanda pelo fator. Como consequiência, a elevação da densidade viária ocasionou queda nos preços de terra nesses estados.

O último grupo compreende os estados com alto valor do parâmetro de densidade viária, porém, não significativo. Estão entre eles: Rio de Janeiro, Espírito Santo, Paraná, Santa Catarina e Rio Grande do Sul. Tais estados, segundo os autores, podem ter atingido uma saturação tal que o aumento da densidade viária não teve mais condições de expandir, de maneira significativa, a fronteira agrícola.

Vale ressaltar que é difícil concluir com precisão a relação existente entre preço da terra e estrutura viária. Para exemplificar essa afirmativa, pode-se pensar no caso da construção (ou melhoria) de uma estrada que ligue uma certa área fértil (área A) a uma outra área com mesma fertilidade, porém que esteja ao redor de um centro consumidor (área B), ocasionando variações nos preços de terras em sentidos diferentes. Os preços de terra na região A elevam-se, uma vez que aumentam os preços pagos ao produtor. Já os preços de terra na área B sofrem queda, uma vez que os preços pagos ao produtor, nesta região, diminuem. Nota-se, portanto, que a relação entre preço da terra e aumento de infra-estrutura é difícil de ser interpretada, sendo necessários mais estudos para se chegar a conclusões precisas. 
Oliveira e Costa (1977) observaram a importância do nível tecnológico na explicação do diferencial de preço da terra entre regiões. Notaram ainda que a elevação dos preços da terra no Brasil, de 1971 a 1974, ocorreu, principalmente, em decorrência da evolução da relação entre preço recebido pelo agricultor e preço dos insumos. Tal evolução esteve intimamente ligada à ação governamental, especialmente à política agrícola do período em análise, a qual visou estabelecer preços favoráveis ao setor e estimular a adoção de novas técnicas (elevando a produtividade da terra). $\mathrm{O}$ argumento é que ao se aumentar a produtividade da terra determinou-se uma elevação na renda desse fator (ou no aluguel da terra) e, conseqüentemente, no preço por hectare do ativo.

Concluindo o estudo, os autores enfatizaram ser provável a existência de uma relação entre preço da terra e infra-estrutura governamental, relação esta que pode seguir uma mesma trajetória, nos diferentes estados. Em primeira instância, o impacto da melhoria em infra-estrutura pode reduzir o preço da terra. Em seguida, passa-se a uma relação positiva entre preço de terra e infra-estrutura até atingir-se um limite de saturação tal que qualquer esforço do governo em melhoria de infra-estrutura não resultará em alterações nos preços de terra. Ou seja, o mercado de terra, a partir desse ponto, não responde a quaisquer investimentos em infra-estrutura.

Os autores notaram ainda a importância de duas variáveis na determinação dos preços da terra: a tecnologia e a relação entre preço recebido e preço pago na agropecuária. Primeiramente, o uso da tecnologia na agropecuária determinaria as diferenças de produtividade e conseqüentemente dos preços de terra entre os estados. Em segundo lugar, a razão entre preço recebido e preço pago pelos agricultores como principais determinantes do preço de venda da terra, no período 1971-74.

Oliveira e Costa (1977) levantaram ainda duas variáveis importantes que não foram abordadas no trabalho: distância do mercado consumidor e inflação. Ressaltaram que tais variáveis seriam de grande contribuição se fossem incorporadas ao estudo.

Sayad (1977a) procurou analisar o papel da política de intervenção governamental via crédito em alguns setores da economia, assim como examinar a 
influência desse crédito sobre a concentração de renda e de riqueza na economia brasileira.

O autor propôs um modelo no qual foram analisadas as possibilidades de substituição entre crédito subsidiado e outras formas de financiamento. Através desse modelo, teve o intuito também de analisar a eficácia de uma política de crédito destinada a um determinado setor da economia. Argumentou que dada uma taxa de juros mais baixa e outra mais elevada em mercados diferentes, o tomador de empréstimos sempre escolherá tomar recurso emprestado à taxa de juros mais baixa e aplicá-lo no mercado que the trouxer maior retorno ao capital investido. Constatou esse fato ao analisar a eficácia do crédito rural na agricultura.

Houve uma particularidade quanto ao mecanismo de concessão de crédito rural. A exigência para que o empréstimo fosse feito ia além dos mecanismos de eficiência. Ou seja, a terra era a "prova" de que havia um envolvimento entre o tomador de empréstimo e a agricultura. Não obstante, tal política implicou elevação dos preços desse fator.

Como resultado de seu estudo, Sayad (1977a) notou que a política de cédito, incluindo o crédito rural, foi de pouca eficácia e altamente concentradora de renda e riqueza.

Sayad (1977b), em sua análise sobre o preço da terra e mercados financeiros, argumentou que na economia brasileira, no período de 1967 a 1973, a terra serviu como reserva de valor alternativa ao capital produtivo. $\mathrm{O}$ autor desvinculou totalmente a terra de sua função como fator produtivo pois afirmava que a característica de reserva de valor era o mais importante dos investimentos em imóveis na época. Dessa maneira, a determinação do preço da terra ocorreria em função da demanda, já que o ativo possui elasticidades de oferta e substituição muito pequenas. Elevações nos preços da terra seriam, portanto, atribuídas à demanda especulativa. Assim, a terra constituía-se em um ativo real capaz de transferir poder de compra de um período para outro. 
A utilização da terra como reserva de valor trouxe, na opinião do autor, algumas consequiências negativas a outros setores da economia, mais especificamente aos setores produtivos.

Um primeiro problema importante que poderia surgir do fato de a terra ser alvo de investimento especulativo estaria relacionado à poupança privada. $\mathrm{O}$ autor notou que esses investimentos, ao serem destinados à compra de terra, poderiam afetar a taxa de formação de poupança privada da economia que deveria ser destinada ao capital produtivo.

Uma segunda consequiência importante da utilização de terras como reserva de valor seria a de que o setor privado, ao escolher a terra como reserva de valor apenas, tomando-a, portanto, como um ativo não-produtivo, passaria a influenciar a taxa de crescimento do estoque de capital produtivo. Um evento qualquer que reduzisse a taxa de retorno esperada dos ativos não-produtivos (como a queda na relação de trocas para a agricultura) poderia aumentar a taxa de crescimento do estoque de capital produtivo, mesmo nos períodos em que tivesse diminuído a taxa de crescimento do produto. $\mathrm{O}$ contrário também seria verdadeiro. Um evento qualquer que elevasse a taxa de retorno esperada dos ativos não produtivos (como a elevação da relação de trocas para a agricultura) poderia reduzir a taxa de crescimento do estoque de capital produtivo, mesmo quando a taxa de crescimento do produto estivesse elevada.

Sayad (1977b) mencionou ainda os prováveis motivos que fizeram da terra o ativo mais procurado como reserva de valor. O primeiro deles vem de uma perspectiva histórica. Quando o autor realizou o estudo, havia pouco tempo que a economia brasileira tinha perdido suas características basicamente agrícolas. $\mathrm{O}$ crescimento populacional pressionando a demanda por terras e a inércia (a escolha da terra como reserva de valor por alguns faz com que outros também a escolham) foram identificados como fatores que impulsionaram a demanda por terra com a finalidade de reserva de valor. 
O autor incluiu também a forma de organização dos sistemas judiciário e fiscal e do próprio setor financeiro como motivos para a maior procura por imóveis como reserva de valor. A lentidão do sistema judiciário brasileiro simultaneamente à fixação de multas, penas e ressarcimentos em valores nominais tornaram arriscados os investimentos no mercado financeiro e lucrativas as falências e concordatas, principalmente sob altas taxas de inflação. Desde 1964 o sistema financeiro esteve em constante mudança (impostos, controle dos juros, alterações nas regras de correção monetária), o que incentivou a concentração da riqueza do setor privado em ativos não financeiros, como a terra.

O autor observou ainda a existência de relações entre preço de terra e ritmo de crescimento da economia, entre investimentos imobiliários e em ações e entre preço da terra e acesso ao crédito financiado.

No primeiro caso, a redução do ritmo de crescimento da economia traduziu-se em aumento na demanda por terra, para amortecer a possível queda de rentabilidade do capital produtivo. Em conseqüência, seu preço se elevou. Do ponto de vista do setor privado, observou-se também a existência de uma relação inversa entre investimentos imobiliários e ações. Essas duas opções mostraram-se substitutas de investimento no período analisado. O direito ao crédito subsidiado também foi um fator que contribuiu para a elevação do preço da terra rural no Brasil.

Sayad (1977b) concluiu que enquanto os retornos aos investimentos imobiliários não se reduzissem seria muito difícil que o sistema financeiro obtivesse melhor desempenho na economia brasileira. Sugeriu, então, uma taxação dos ganhos de capital. Argumentou que sem essa intervenção dificilmente o setor financeiro ofereceria um ativo rentável o suficiente, capaz de competir com aqueles que serviam como reserva de valor. Enfatizou que sob altas taxas de inflação, os ativos financeiros só competiriam com outras formas de retenção de riqueza se oferecessem proteção adequada contra a inflação. Finalizou afirmando que o setor financeiro teria uma tarefa importante em todo esse processo, a qual seria alterar os hábitos de poupança do setor privado em função de todos os motivos previamente discutidos. 
Apesar de notar a influência de outros fatores na formação e na variação dos preços da terra, como a razão de preços entre agricultura e indústria e o nível de atividade econômica do país, Sayad (1977b) enfatizou o papel da terra como reserva de valor, afirmando ter sido este o principal determinante do preço do ativo em questão.

Segundo Agroanalysis (1977), o subsídio ao crédito rural surtiu grande efeito nos preços da terra para aquelas culturas que tinham acesso ao crédito e que dependiam desse recurso.

O estudo verificou que havia uma relação entre área colhida e taxa de juros real do crédito rural (diferença entre taxa de juros nominal e taxa de inflação) para custeio de algumas culturas. Examinou três culturas quanto às suas ligações com o crédito rural.

A primeira delas foi a soja, cujos altos preços internacionais garantiam, na época, uma alta rentabilidade relativa ao custo médio de produção. Assim, a expansão dessa cultura mostrou-se muito pouco dependente da taxa de juros real do crédito rural.

O cultivo do milho w Brasil era concentrado em pequenos estabelecimentos, os quais se deparavam com custos à taxa de juros de mercado. Esses produtores dificilmente tinham acesso ao crédito subsidiado. Assim, o crescimento da cultura do milho pouco respondia a variações no grau de subsídio ao crédito rural.

A pesquisa verificou ainda que quanto maior a necessidade de capital de giro no custo total da atividade, maior seria a influência do subsídio sobre o desempenho da cultura. Como exemplo citou-se o algodão, que possui elevado custo de produção por hectare, em relação a outras lavouras. Notou-se, portanto, uma alta correlação entre o grau de subsídio ao crédito de custeio e a expansão da cultura do algodão.

Agroanalysis (1977) mostrou, portanto, que houve uma relação entre a taxa de juros real do crédito rural de custeio e a expansão da área de algumas lavouras. A elevação dos preços da terra surgiu exatamente do aumento na demanda por esse fator em virtude da relação existente entre grau de subsídio ao crédito e expansão da área cultivada (aumento da rentabilidade de algumas culturas). 
Rangel (2000) ${ }^{4}$ interpretou os determinantes clássicos do preço da terra (renda da terra e taxa de lucro da economia) de uma maneira distinta daquela elucidada pela literatura até então. Para este autor, a renda da terra permanece relativamente constante em quaisquer fases do ciclo econômico (ou cai muito pouco). Dessa maneira, durante a queda cíclica, a terra constitui-se em um ativo desejado. A taxa de lucro da economia, por sua vez, varia conforme o ciclo econômico, levando o preço da terra a variar em sentido contrário. Esse comportamento anticíclico do preço da terra, segundo o autor, induz a uma expectativa de elevação do seu preço, independentemente da renda que ela possa gerar. O autor denominou essa expectativa de valorização do ativo de quarta renda da terra.

Segundo o autor, já que a oferta de terras era crescente devido às inovações agronômicas e avanços da infra-estrutura, a demanda pelo ativo, graças à expectativa de sua valorização, é quem determinaria o preço da terra. Para Rangel (2000), são unicamente as variações de natureza não-agrícola que afetam o comportamento dos preços desse fator de produção.

Pinheiro (1980) estudou as principais teorias existentes na literatura sobre renda e preço da terra e analisou a aplicação empírica dessas teorias na agricultura brasileira.

O principal objetivo de seu estudo foi mostrar que variáveis econômicas e outras variáveis não ligadas diretamente ao processo produtivo agrícola influenciaram a formação dos preços da terra no Brasil, de 1966 a 1978. Isso trouxe grandes conseqüências para o setor agrícola. Dentre elas, pode-se destacar o prejuízo do desenvolvimento capitalista da atividade produtiva agrícola, a entrada de outros grupos sociais no setor e o interesse desses grupos na manutenção da estrutura fundiária da época.

Com relação ao arrendamento, o autor estimou, através de regressão linear simples, a taxa média geométrica de crescimento anual desses preços, de 1966 a 1978.

\footnotetext{
${ }^{4}$ Essas idéias de Rangel foram publicadas inicialmente em 1979 e reeditadas em 2000.
} 
Posteriormente, comparou as taxas de crescimento do preço real de arrendamento com as taxas de crescimento da remuneração real do trabalho e de empreitadas.

Como resultado, verificou que em sete dos oito estados onde o preço de arrendamento cresceu fortemente, o maior crescimento ocorreu em arrendamento para lavouras e, dentro desses arrendamentos, o crescimento do preço ficou concentrado em culturas mais ligadas à exportação ${ }^{5}$, as quais foram favorecidas pela política econômica vigente no período. Concluiu, então, que os preços de arrendamento sofreram grande influência da atividade econômica desenvolvida na agricultura, não sendo, portanto, um movimento geral de preços dentro de uma região.

Ao comparar as taxas de crescimento do preço real de arrendamento com as taxas de crescimento da remuneração real do trabalho e de empreitada,s notou que as primeiras comportaram-se de maneira mais desuniforme que as últimas.

Pinheiro (1980) pesquisou também os principais componentes da formação do preço de venda de terras agrícolas. A seguir, estudou a evolução dos preços da terra nas diferentes atividades e em diversos estados brasileiros, comparando-a com a evolução dos preços de arrendamento, remuneração do trabalho e serviços de empreitada na agricultura.

O autor defende a teoria de que os preços de terra são influenciados pela decisão do agricultor de expandir sua atividade, ou seja, pela demanda do agricultor por terra, puramente relacionada com a produção. Essa decisão, por sua vez, dependeria da rentabilidade da agricultura, a qual poderia ser analisada utilizando-se os termos de troca, sendo o índice mais adequado para tal a relação entre preços recebidos e preços pagos pelos agricultores. Entretanto, as evidências empíricas não validaram a hipótese de que os preços de terra são determinados principalmente pela rentabilidade da agricultura.

${ }^{5}$ São os estados: RN (algodão arbóreo), PE (cana-de-açúcar), AL (cana-de-açúcar), ES (café e cana-deaçúcar), RJ (cana-de-açúcar e banana), PR (soja) e RS (soja) . 
Pinheiro (1980) discordou de Sayad (1977b) quando este argumentou que o processo especulativo em terras ou em qualquer outro ativo era originário de uma insuficiência do sistema financeiro. Para Pinheiro (1980), o próprio processo de desenvolvimento da economia brasileira explica esse processo especulativo. Entretanto, ressaltou que embora a insuficiência do mercado financeiro não tenha criado o processo especulativo sobre os preços de terra, participou ativamente desse sistema em algumas fases. Tal participação ocorreu por três motivos principais: pela legislação tributária; incentivos de políticas econômicas que protegiam a concentrada posse da terra, e pelo não investimento de parte da poupança em atividades produtivas.

O autor também não observou o comportamento anticíclico dos preços de terra, levantado por Rangel (2000). Verificou que o período de rápida expansão econômica no Brasil coincidiu com a fase em que os preços da terra estiveram mais elevados. Já na fase da economia em queda, os preços de terra mostraram-se estáveis.

Comparando as taxas médias geométricas de crescimento anual dos preços de venda da terra e do arrendamento, notou que, ao contrário do que fora constatado para as taxas de crescimento do preço do arrendamento, não houve para os preços de venda da terra, uma diferença em seu comportamento entre as atividades. Notou apenas diferença de comportamento desses preços entre regiões ou estados. Isto é, dentro de um estado ou região, os preços de venda dos diferentes tipos de terra (lavoura, pastagem, campo e mata) apresentaram-se correlacionados, diferentemente do observado com o preço do arrendamento. Concluiu, então, que o preço do arrendamento está intimamente ligado a fatores intrínsecos à produção agropecuária, enquanto que o preço de venda de terras agrícolas sofre influência direta de fatores externos ao setor.

Buscando encontrar explicações para as fases de acentuada elevação dos preços da terra (1971 a 1975), Pinheiro (1980), baseado em teorias previamente elaboradas, selecionou algumas variáveis relacionadas direta (ligadas ao processo produtivo agrícola) e indiretamente (externas ao setor agrícola) aos preços da terra e do arrendamento. Tais variáveis seriam: relação entre índice de preços recebidos pelos 
agricultores (SP) e índice de preços pagos pelos agricultores (SP); inflação; subsídio do crédito rural ${ }^{6}$; produto real agrícola e produto real industrial.

Com relação aos termos de troca, o autor observou um paradoxo: enquanto os preços de terra estavam relativamente altos (período de 1971 a 75), os termos de troca encontravam-se estáveis; quando os preços de terra mantiveram-se estáveis, a relação entre preços recebidos e preços pagos pelos agricultores mostrou-se ascendente. $\mathrm{O}$ autor concluiu, então, que os termos de troca não puderam explicar a alta de preços da terra no período de 1971 a 1975.

Com relação à taxa de subsídio do crédito rural, o autor chamou a atenção para alguns pontos. O primeiro é que o período de preços de terras mais elevados coincidiu com a fase de menores taxas de subsídio do crédito rural, concluindo que essa variável não foi fundamental para explicar a alta de preços de terra no período 1971 a 1975. Uma segunda observação advém justamente dessa alternância entre preços de terra e taxa de subsídio do crédito. No período pré e pós 1971-75, os altos subsídios compensavam o pequeno ganho especulativo com terra, advindo dos preços baixos. Portanto, ou o indivíduo (principalmente os grandes proprietários que tinham acesso ao crédito) ganhava com a especulação (na fase de altos preços de terra) ou com a taxa de subsídio.

O autor notou também que os altos subsídios do crédito rural não levaram a acréscimos na produção agrícola, já que enquanto a taxa de subsídio superava os $20 \%$ ao ano, nos anos de 1966 e 1976-78, as taxas de crescimento do produto real agrícola mostravam-se negativas.

É interessante apontar que ao se estimar a taxa de subsídio do crédito rural não

está sendo considerado o montante de subsídio concedido, podendo gerar conclusões não tão precisas. Assim, altas taxas de subsídio poderiam não ser o atrativo suficiente capaz de gerar maior demanda por terras, pela possibilidade de haver pouco volume de

\footnotetext{
${ }^{6}$ Calculado pelo autor como a diferença entre a taxa anual de inflação e uma taxa anual média dos juros de crédito rural, estimada em $15 \%$ a.a.
} 
crédito rural disponível (e/ou dificuldade de acesso a esse recurso).

Quanto à taxa de inflação, Pinheiro (1980) notou que essa variável também não foi fundamental para explicar a alta de preços de terras no período 1971-75. A inflação apresentou o mesmo comportamento da taxa de subsídio do crédito rural, com relação ao preço da terra. $\mathrm{Na}$ fase de preços de terras altos, a taxa de inflação manteve-se baixa, enquanto que nas fases antecedentes e posteriores ao período 1971-75, mostrou-se elevada.

Assim, Pinheiro (1980) concluiu que a ascensão dos preços da terra foi resultante das próprias características do processo de desenvolvimento econômico brasileiro, principalmente da fase do "milagre brasileiro". Nas palavras do autor: "Essa fase gerou ou acentuou a existência de um processo especulativo, possibilitando que certos grupos sociais participassem dos resultados do processo de desenvolvimento, sem que necessitassem ou tivessem possibilidade de obter esta participação através do processo produtivo" (Pinheiro, 1980, p.171).

Tendo em vista as lacunas nos trabalhos que até então tentavam explicar os determinantes do preço real de venda de terras, o autor escolheu duas variáveis para seu estudo econométrico: preço real de arrendamento e inflação.

A primeira delas, o preço real de arrendamento, representa vários fatores ligados diretamente à produção agrícola, considerada pelo autor como componente fundamental do preço da terra, pois representa a renda capitalista da terra. Porém, é necessário levar-se em consideração que o preço do arrendamento em uma parte da atividade agrícola pode não ser representativo da agricultura como um todo.

A variável inflação estaria associada a fatores externos à atividade agrícola, representando a atratividade do fator como reserva de valor ${ }^{7}$, motivo de especulação, etc.

\footnotetext{
${ }^{7}$ O autor utilizou o termo reserva de valor não para os processos de obtenção de ganhos reais da aplicação ou para proteger o capital financeiro contra desvalorização, mas sim, para representar uma forma de aplicar o dinheiro com finalidade não-produtiva e reavê-lo posteriormente, ao vender a terra.
} 
O autor notou que, principalmente no período 1971-75, com efeitos defasados no tempo entre estados, apenas as variáveis escolhidas não foram suficientes para explicar o crescimento do preço real de venda da terra. Argumentou ainda que essa lacuna modelo deveu-se àfase em que a economia brasileira encontrava-se, o período conhecido como "milagre brasileiro". De acordo com o autor, grande parte da poupança nacional não fora investida em setores produtivos (as taxas não eram atraentes), o que gerou ou acentuou o processo especulativo.

As variáveis inflação e preço real de arrendamento explicaram melhor, segundo Pinheiro (1980), os preços reais de venda das terras de pecuária que os de lavoura.

Em São Paulo, na atividade lavoura, o preço de arrendamento e inflação explicaram, conjuntamente, $95 \%$ das variações ocorridas no preço real de venda de terras agrícolas, no período em questão.

São Paulo foi o estado que teve maior representatividade no preço de arrendamento, em termos de renda capitalista da terra, e do possível preço médio de arrendamento para toda a área de lavoura do estado. Assim sendo, pelos resultados notou-se que um aumento de $10 \%$ no preço real de arrendamento levou, no período considerado, a um aumento de quase $20 \%$ no preço real de venda da terra. Observou-se que quanto mais capitalistas forem as características do arrendamento e quanto mais representativos forem os preços do arrendamento em relação ao possível preço do arrendamento de toda a área de lavoura do estado, maior a sua influência no preço de venda da terra. Assim, considerou-se pequeno o efeito da inflação sobre os preços de venda de terra agrícola na atividade lavoura, no estado de São Paulo.

Já para a pecuária em São Paulo, os valores de elasticidade preço de arrendamento encontrados foram mais baixos, uma vez que há menor incidência de arrendamento nessa atividade.

Concluindo, Pinheiro (1980) levantou dados que mostraram que os ganhos com a valorização da terra foram superiores aos possíveis ganhos com arrendamento e aos 
possíveis lucros na agricultura. Dessas análises notou que a terra tornou-se muito atrativa para fins especulativos e de reserva de valor e não como fator de produção, como deveria ser. Assim, surgiram os latifúndios com aptidões agrícolas mas subinutilizadas, agravando a problemática da alta concentração da posse de terra no Brasil.

Pinheiro e Reydon (1981) estudaram os preços da terra no Brasil, de 1966 a 1978, relacionando-os com a questão agrária, então em discussão.

Notaram que o preço de venda da terra, para a maioria dos estados, superou o preço do arrendamento capitalizado, assim como notado por Pinheiro (1980). Concluíram, então, que houve fatores indiretamente ligados à produção agrícola na determinação dos preços da terra; caso contrário, o preço da terra seria igual à sua renda capitalizada.

Esses autores discordaram de Rangel (2000) quando esse afirmou que haveria aumento na demanda por terras (e conseqüentemente nos seus preços) quando a taxa de lucro da economia estivesse em queda, desde que a renda da terra não caísse ou fosse menor que a do mercado de capitais.

Pinheiro e Reydon (1981) mostraram, assim, que não é necessário que a taxa de lucro da economia esteja em queda para que os preços da terra se elevem. Em 1971, os preços de terra iniciaram sua fase de crescimento, coincidindo com um grande crescimento da economia brasileira (1968 a 1974) em que a taxa de lucro não apresentava sinais de queda. O mesmo foi observado por Pinheiro (1980).

Ressaltaram terem existido fortes indícios de que, no período de maior expansão da economia brasileira, intensificou-se o processo especulativo sobre terras agrícolas. Inicialmente o processo especulativo ocasionado pela expansão da economia fora canalizado para a Bolsa de Valores. Após sua quebra, o processo desviou-se para o mercado de terras.

Para esses autores, o modelo de desenvolvimento vigente no período, com ênfase no desenvolvimento industrial, foi incapaz de canalizar parte da poupança 
privada para fins produtivos. Isso gerou elevação na demanda por terra com finalidade não-produtiva, elevando os preços desse fator e realimentando o processo especulativo. Fortaleceu-se, assim, o monopólio da terra, impondo barreiras ao seu acesso.

Castro (1981) realizou um estudo detalhado sobre a estrutura fundiária do país, de 1930 a 1980, traçando um paralelo entre esta e a evolução da agricultura, ressaltando também, as principais relações entre elas. Em sua análise, assim como previamente observado por Pinheiro (1980) e por Pinheiro e Reydon (1981), notou que a evolução das questões agrícolas, especialmente a concentração fundiária, estava intimamente ligada à evolução do modelo de desenvolvimento econômico adotado pelo país. Nesse modelo, o setor agrícola era encarado apenas como repassador de recursos financeiros (via confiscos e tabelamentos) e transferidor de recursos humanos (emigração) para sustentar o crescimento urbano-industrial. $\mathrm{O}$ financiamento à industrialização e aos investimentos em infra-estrutura urbana estavam baseados fortemente na tributação sobre as exportações agrícolas.

O autor enfatizou que a atuação de políticas governamentais, principalmente sobre os produtos para o mercado interno, impediu que o mercado agrícola agisse naturalmente. Isso fez com que a rentabilidade da agricultura fosse reduzida em comparação com o valor da terra. Consequientemente, houve uma busca maior por terras, já que ao longo desses anos a imobilização em terra garantiu retornos alinhados com aqueles auferidos por outros ativos. Assim, notou-se um incentivo à expansão horizontal da agricultura em detrimento do interesse em se investir na intensificação do processo produtivo em si.

O autor ressaltou que a rentabilidade da atividade agropecuária deveria ser menos dependente da expectativa de valorização patrimonial. Argumentou que este viés proporciona baixo nível de indução produtiva às propriedades de grande extensão, elevação dos índices de concentração das áreas de imóveis e prejudica a pequena produção quanto à possibilidade de maiores chances de capitalização. Com relação à aquisição de tecnologia, a valorização patrimonial, por motivos diferenciados, não induz 
os pequenos e nem mesmo os maiores estabelecimentos a buscar acréscimos de produtividade, em termos de área explorada.

Segundo o autor, os períodos de grande liquidez financeira do país associados numa primeira fase à aceleração do crescimento econômico (1970 - 1973) e depois, a episódios de aceleração inflacionária e ampliação de subsídios creditícios contribuíram para elevar a taxa de apreciação do valor da terra, como reserva de valor.

Castro (1981) questionou o papel atribuído à inflação na valorização da terra. Incorporou a questão da liquidez à sua linha de raciocínio. Argumentou que se o processo inflacionário coincidisse com períodos de menor expansão econômica e houvesse controles à expansão do crédito, a liquidez nominal poderia ser elevada, mas a liquidez real poderia estar caindo. Portanto, nesse caso, o elemento fundamental não é o processo inflacionário em si, mas a disponibilidade real em ativos monetários. Citou como exemplo o período de 1971-1973, quando a inflação era cadente mas a liquidez real crescente.

A fim de caracterizar as propriedades agrícolas, Castro (1981) sugeriu uma divisão em três tipos de estabelecimentos rurais, segundo sua atividade ou destinação: a produção de baixa renda, a produção profissionalizada e o investimento patrimonial.

$\mathrm{Na}$ produção de baixa renda estão todas as formas de produção de baixo nível tecnológico e poucas possibilidades de capitalização. Os agricultores defrontam-se com restrições de área física, de acesso a financiamentos e de acesso à propriedade do solo cultivado. Esse grupo pratica a agricultura tradicional, com produtos voltados ao mercado interno e de oferta instável. Muitos são não-proprietários.

O autor motou que, dada a valorização patrimonial da terra, havia a tendência de os pequenos produtores saírem da atividade, uma vez que para esses indivíduos é mais atrativo vender sua propriedade e trabalhar como assalariado no próprio setor ou fora dele. 
Para a categoria de produção profissionalizada (a segunda categoria), o fundamental é que, independentemente do seu tamanho, haja uma relação estável e suficientemente rentável do produtor com sua atividade, possibilitando-lhe o desenvolvimento e a capitalização de sua produção. Podem ocorrer formas combinadas de produção profissionalizada com a categoria seguinte, a de valorização patrimonial, principalmente em se tratando de estabelecimentos rurais de grande extensão.

Nesta última categoria, o que define a relação entre o homem e a terra não é o tamanho da área mas sua destinação. Os investidores são os indivíduos que possuem um excesso de liquidez que precisa ser imobilizado de alguma forma a fim de obter valorização. A atividade fim não é a produção e sim a valorização esperada do patrimônio imobiliário. Não aderem à atividade agrícola para aumentar sua renda porque não possuem o conhecimento específico necessário para tal. Normalmente, uma área como essa está associada a terras de produtores profissionalizados ou ela é arrendada a terceiros.

Castro (1981) observou que a lucratividade na agricultura pode se transferir para o mercado de terras e para o de mão-de-obra. Espera-se que nos períodos de alta de preços agrícolas os capitais financeiros sejam atraídos para a aquisição de estabelecimentos rurais, competindo nesse mercado imobiliário com os produtores profissionalizados, que também se expandem. Estes, porém, são impulsionados, na maior parte dos casos, pela maior lucratividade de produção, enquanto aqueles rão têm como objetivo principal a produção, mas uma esperança de ganho financeiro.

O autor elegeu como propulsores do preço da terra, no período por ele analisado, os seguintes elementos: o aumento da taxa de lucro da produção, o grau de liquidez real da economia ligado a fases de prosperidade, o crédito rural, obras de infraestrutura realizadas pelo governo, o programa nacional do álcool e os incentivos fiscais.

Nota-se, portanto, que este autor possui uma visão oposta à de Sayad (1977b) e de Rangel (2000), ao observar a relação entre preço da terra e ciclo econômico. Enquanto os últimos defenderam a existência de uma relação inversa entre nível de 
atividade econômica e preço da terra, Castro afirmou que quanto maior fosse a liquidez da economia, maior seria o volume de recursos destinado à compra de terras, sob expectativa de valorização patrimonial. Castro (1981) considerou também que a lucratividade da agricultura é um fator crucial na formação do preço da terra

Sayad (1982) analisou os efeitos do novo Imposto Territorial Rural (ITR) sobre a especulação em terras rurais e sobre a produção agrícola. O propósito das mudanças na legislação do imposto era o de incentivar o aumento da demanda por terras ainda não utilizadas, a fim de expandir a produção agrícola.

$\mathrm{O}$ autor argumentou que, funcionando a terra como reserva de valor, a formação de seu preço dependeria essencialmente da expectativa dos investidores com relação à valorização desse fator, independendo quase que totalmente dos custos de incorporação de novas terras agrícolas. Um segundo determinante seriam os lucros que a atividade agrícola poderia gerar.

Assim, o comprador de terra teria a expectativa de que a taxa esperada de crescimento dos preços da terra mais os lucros da atividade agrícola fossem maiores que o ganho esperado em ativos alternativos. O vendedor, ao contrário, esperava que o rendimento do ativo alternativo fosse maior que o ganho com o crescimento dos preços da terra, somado aos lucros da atividade agrícola.

Ao crédito rural subsidiado também foi atribuído papel de destaque na determinação do preço da terra, assim como ao grau de liquidez da economia. Maior liquidez gera maior demanda por ativos financeiros e não financeiros, aumentando a procura e o preço de terras. Esta observação está de acordo com o que Pinheiro (1980), Pinheiro e Reydon (1981) e Castro (1981) notaram, porém diferiu daquela obtida por Rangel (2000) e por Sayad (1977b).

Quanto à influência da inflação sobre a demanda por terras rurais, Sayad (1982) argumentou que apenas o fenômeno inflacionário não bastaria para aumentar a procura por terras para fins de proteção. Era preciso que a inflação fosse acompanhada por taxas 
de juros de ativos financeiros, controladas pelo gverno e que estivessem abaixo da taxa de inflação, para que o mercado de imóveis se tornasse preferencial aos ativos do mercado financeiro.

O autor concluiu que a mudança no ITR só teria efeito sobre o aumento da produção agrícola se fosse mais vantajoso cultivar a terra do que pagar o imposto. Notou ainda que esse efeito seria tanto maior quanto maiores fossem as expectativas de valorização da terra, ou seja, quanto maiores fossem os ganhos especulativos com a terra. Se fosse mais vantajoso cultivar a terra do que pagar imposto, ainda que o cultivo desse prejuízo, a expectativa de valorização com o componente ganho de capital mais do que compensaria essa perda na atividade.

Rezende (1982a) realizou um estudo sobre o crédito rural subsidiado e o preço da terra no Brasil. Pretendeu analisar a eficácia do subsídio creditício e a influência desse mecanismo na elevação do preço da terra.

A literatura existente até então argumentava que o subsídio ao crédito rural era responsável pela elevação do preço da terra, uma vez que a relação entre preço da terra e arrendamento elevara-se depois da instituição desse sistema.

O objetivo da política de crédito rural era incentivar investimentos na agricultura criando uma compensação ao setor, em relação aos demais setores da economia. Porém, nesse sistema os tomadores de empréstimos não olhavam para o subsídio ao crédito rural como um mecanismo de financiamento da produção, mas como uma alternativa para se obter rentabilidade no setor mais lucrativo que existisse na economia. Ou seja, o tomador só investiria na agricultura se não houvesse uma alternativa mais rentável na economia.

Mesmo que o crédito subsidiado fosse concedido sob a condição de ser aplicado exclusivamente na agricultura, não havia como impedir que o recurso funcionasse como capital em geral. A demanda por crédito subsidiado, num dado momento, passou a ser extremamente elevada. Como a quantidade de terra agrícola era 
finita e para usufruir do crédito rural era necessário ser proprietário do fator, era natural que o preço da terra se elevasse para além da renda da terra.

$\mathrm{O}$ autor notou um fato interessante no que diz respeito à lucratividade dos tomadores de crédito rural. Com o aumento do preço da terra, o indivíduo que desejasse tomar crédito subsidiado arcaria com dois custos. Primeiramente arcaria com o custo do juro do crédito rural e, posteriormente, com o custo de oportunidade do dinheiro que investiria em terra (já com valor mais elevado), para adquirir o crédito rural subsidiado. Enquanto fosse vantajoso (houvesse maior retorno) arcar com o custo do juro subsidiado do crédito rural e com o custo de oportunidade do dinheiro imobilizado em terra, os indivíduos escolheriam investir em terras recebendo crédito subsidiado ao invés de aplicar seus recursos no mercado financeiro. Com isso haveria a tendência de equalização da taxa de juro no mercado como um todo.

Desta maneira, o produtor agrícola que desejasse adquirir terras teria que fazêlo sob um preço mais elevado. Caso o agricultor não se apropriasse do subsídio estaria deixando de obter a taxa de lucro média sobre o capital fixo e sobre o valor da terra. $\mathrm{O}$ mesmo aconteceria para os indivíduos que já possuíssem terras e tivessem que manter uma quantia elevada imobilizada nesse fator.

O autor analisou ainda o lado do arrendatário. Esse indivíduo beneficiar-se-ia do subsídio ao crédito sem ter que se apropriar do fator de produção. Assim, sua taxa de lucro só se reduziria caso o valor do arrendamento da terra aumentasse. Se isso ocorresse, o proprietário da terra ficaria indiferente entre arrendá-la a terceiros ou produzir recebendo crédito no Sistema Nacional de Crédito Rural. Essa indiferença mostra que o arrendamento poderia se elevar independentemente da utilização do crédito subsidiado pelos proprietários. O autor concluiu que a elevação do preço da terra causou uma elevação de caráter puramente financeiro do arrendamento, tornando-o superior ao que seria observado em função apenas da renda agropecuária.

Surgiu, desta maneira, um impasse na agricultura. $O$ setor deixaria de ser rentável caso não se utilizasse o crédito subsidiado. Tornou-se incapaz de competir com 
os demais setores pelo capital próprio ou pelo mercado financeiro livre, tornando-se totalmente dependente do governo para suprir sua necessidade de crédito rural.

Dois grupos de agricultores foram fortemente prejudicados: os pequenos agricultores e os arrendatários sem acesso ao crédito subsidiado. Os primeiros venderam suas terras pois notaram que esse ativo possuía valor de mercado superior ao valor de seus rendimentos correntes e futuros. O segundo grupo, também excluído do sistema de crédito, era incapaz de pagar a renda da terra acrescida do subsídio.

O autor esperava que com a política de crédito rural houvesse uma elevação do valor do arrendamento mais rápida que a do preço de venda da terra (pois havia uma incerteza sobre o juro subsidiado e mesmo sobre o volume de crédito que seria concedido). Porém, a relação entre arrendamento e preço da terra caiu na década de 70 , contrariando suas expectativas.

Rezende (1982a) concluiu ainda que seria difícil afirmar com certeza que a alta no preço da terra, no período por ele analisado, tivesse ocorrido por causa da política de crédito rural. Nesse mesmo período a economia passou por uma fase de desaquecimento da atividade e de aceleração inflacionária. Com isso, houve uma drástica redução da taxa de lucro média da economia. Assim, ficou muito difícil separar esses vários efeitos na tentativa de explicar a elevação dos preços da terra.

O autor concordou com Rangel (2000) e Sayad (1977b) quanto ao comportamento anticíclico dos preços da terra. Observou que a renda praticamente constante da atividade agrícola, somada ao comportamento da taxa de lucro média da economia fizeram com que o preço de terra variasse de maneira inversamente proporcional ao ritmo de atividade econômica do país. Porém, enfatizou que as evidências empíricas não apoiaram a "autonomização" do preço da terra sugerida por Rangel. Observou ainda que o arrendamento, diferentemente do preço da terra, se relaciona diretamente com as fases cíclicas da economia. 
O autor fez uma última consideração sobre a relação arrendamento/preço da terra. Considerada a principal evidência em apoio à hipótese de uma elevação no preço da terra por efeito do crédito rural, essa razão deve ser estudada conjuntamente com a evolução cíclica da economia, a fim de se obterem resultados satisfatórios.

Rezende (1982b) ampliou seu estudo anterior incorporando o ciclo econômico à análise do preço da terra, conforme havia sugerido.

Ao analisar o comportamento da relação entre arredamento e preço da terra, observou que houve queda em tal razão, entre o início e o fim da década de 70. Com isso, ressaltou que tal observação não deve ser tomada como evidência de capitalização do subsídio no preço da terra por dois motivos principais: primeiramente, o subsídio deveria levar, teoricamente, a uma alta e não a uma queda na relação arrendamento/preço de terra. Além disso, nas palavras do autor, "a evolução cíclica da economia deve ter sido uma força determinante muito mais poderosa, relegando a um segundo plano quaisquer outras considerações".

Assim, ao incorporar o ciclo econômico ao seu estudo, Rezende (1982b) direcionou grande importância a esse fenômeno como determinante do preço da erra, graças ao fato de a renda da terra permanecer constante (ou oscilar muito pouco) durante quaisquer fases da economia.

Em resumo, o autor sintetizou a teoria do preço da terra na fórmula:

$$
P_{i}^{t}=\frac{A_{i}^{t}}{r_{i}^{t}}
$$

em que:

$i=$ tipo de terra;

$t=$ tempo;

$P=$ preço da terra; 
$A=$ valor do arrendamento;

$r=$ taxa de capitalização.

Assim, $r_{i}^{t}$ pode variar acompanhando o ciclo econômico e pode também variar dentro de um ciclo. O primeiro caso consiste em $r_{i}^{t}$ variar no tempo para cima ou para baixo como um todo, conforme o ciclo econômico (relação direta entre essa variável e a taxa geral de lucro da economia). No segundo caso, $r_{i}^{t}$ pode variar em um dado instante $t$ (em uma conjuntura econômica específica), com os diferentes tipos de terra. Como consequiência, há a alteração nos preços da terra se ocorrerem quaisquer mudanças na taxa de capitalização (sendo que a renda da terra é praticamente constante).

Egler (1985) preocupou-se em relacionar o mercado fundiário com o mercado financeiro, estabelecendo a taxa de juros como elo entre eles. Para o autor, nas fases iniciais de desenvolvimento do capitalismo de uma economia, é natural que o mercado fundiário exerça a função de valorizar o capital, exigência do processo de concentração e centralização de capitais.

Porém, explicou que ao se consolidar um sistema financeiro "capaz de valorizar de modo fictício as massas de capital" (Egler, 1985, p.133), os preços de terras rurais oscilariam de maneira inversa ao comportamento da taxa de juros, como observou no caso brasileiro, de 1967 a 1976. Desta forma, surgiu a oportunidade de especular-se nos dois mercados: financeiro e fundiário.

Este autor atribuiu à valorização da terra a necessidade de os indivíduos aplicarem seu capital em algum mercado que tivesse a possibilidade de trazer retornos ao capital investido, assim como sugeriu Sayad (1977b). Egler (1985) designou pouca importância à demanda agrícola como determinante de seu preço, assim como Rangel (2000) . Defendia que a terra teria produtividade crescente graças ao progresso técnico, intensificando o uso do solo. 
Rezende (1985) notou que, no final da década de 60, até meados de 70, houve um aumento na produtividade da terra, levando a acréscimos do preço do arrendamento. Entretanto, observou que os preços da terra apresentaram crescimento à taxa duas vezes maior que a do valor do arrendamento.

$\mathrm{O}$ autor argumentou que com o crédito rural sendo subsidiado houve significativa redução no risco da atividade agropecuária. Assim, a terra tornara-se uma opção mais segura de investimento.

Criticando a idéia de que a elevação nos preços da terra era advinda da utilização deste fator como aval para obtenção do crédito, argumentou: "o atrativo da posse da terra teria aumentado enormemente e o crédito rural teria levado a uma alta no preço da terra não porque, como usualmente se supõe, a terra tivesse de servir de colateral dos empréstimos mas, precisamente, por ter reduzido o cumprimento desse papel" (Rezende, 1985, p.191).

A opinião de Rezende (1985) divergiu da idéia de Rangel (2000) sobre o comportamento constante da renda da terra nas várias fases do ciclo econômico, determinando o alto preço da terra com relação ao aluguel. A crítica foi baseada no fato de o nível de atividade agrícola permanecer constante em quaisquer fases do ciclo econômico, mas o nível de renda não, pois acompanha os preços agrícolas. Quanto à terra, o autor defendeu o argumento de que tanto o seu preço como sua renda corrente devem cair numa recessão, refletindo a crise financeira e a conseqüente liquidação de ativos por parte dos agricultores endividados.

Rezende (1985) enfatizou em seu trabalho a influência do crédito rural nos preços de terra. Para esse autor, o aumento nos preços de terra ocorreu com a diminuição do risco da taxa de retorno da atividade agropecuária, em virtude da presença do subsídio e de outras características advindas de alterações, em 1981, no Sistema Nacional de Crédito Rural. 
Brandão (1986) levantou as hipóteses mais discutidas na literatura relacionadas ao preço da terra e examinou a empiricidade de tais hipóteses. Comparou as rentabilidades da terra de lavoura, de pecuária e de outros ativos financeiros. Decompôs a rentabilidade da terra em ganho de capital e ganho decorrente da renda gerada (valor do arrendamento). Além disso, criou um modelo intertemporal de avaliação dos ativos e, baseando-se neste, procurou estimar um coeficiente de aversão ao risco.

O autor observou que muitos trabalhos brasileiros e até mesmo internacionais utilizaram o modelo financeiro de determinação do preço da terra, em que o preço é o valor presente do fluxo de rendimentos futuros. A crítica foi feita no tratamento dado à taxa de desconto do fluxo de rendimentos. Nas palavras do autor: "esta é, via de regra, considerada constante e, portanto, o preço da terra é determinado pelo quociente do fluxo (constante, na maioria das vezes) de rendimentos futuros e a taxa de desconto. Não é de estranhar, assim, que o preço não reflita variações no fluxo de rendimentos" (Brandão, 1986, p.3).

A partir desse raciocínio, muitos autores chegaram à conclusão, não necessariamente verdadeira, de que a falta de sincronização entre preço e aluguel da terra indicava que outros retornos (que não fossem agrícolas) estariam intervindo no processo de formação desse preço. Dado esse panorama, o autor discutiu um modelo de determinação da taxa de desconto e procurou aplicá-lo ao caso brasileiro.

Avaliou através de análise de regressão as relações entre preço real da terra e as seguintes variáveis: montante de crédito agrícola no ano, preço recebido pelos agricultores e hiato do produto como proxy representativa do ciclo econômico.

O autor observou que o crédito subsidiado apresentou coeficientes significativos somente nas regressões de preço de terra de lavoura. Sugeriu incorporar à análise as expectativas do produtor quanto ao valor esperado de crédito subsidiado em um horizonte temporal, e não somente o volume de crédito concedido hoje. 
A variável preço recebido pelos produtores mostrou-se significativa e positiva somente para o preço e aluguel de terras para pecuária. Novamente o autor incorporou a questão das expectativas à análise como resposta da falta de significância da variável para terra de lavoura. $\mathrm{O}$ autor mencionou a possibilidade de os produtores formularem estimativas de preços recebidos futuros e que essas estimativas poderiam não estar sendo bem representadas pelos preços correntes.

Os resultados obtidos com o hiato do produto, aparecendo sempre com sinal positivo, indicaram que o ciclo econômico operava no mesmo sentido sugerido por Rangel (2000), Sayad (1977b) e Rezende (1982a). A hipótese de Rangel de que a renda da terra não varia durante as fases do ciclo econômico se confirmou no caso do aluguel de terras para pecuária.

Brandão (1986), ao comparar a rentabilidade do investimento em terra com a de outros ativos financeiros, demonstrou que a terra seria capaz de competir com as demais alternativas por recursos no mercado financeiro. $\mathrm{O}$ ativo terra mostrou-se rentável e com coeficiente de variação pequeno em relação ao dos ativos com melhor rentabilidade. $\mathrm{O}$ autor observou ainda, que na divisão de rentabilidade entre ganho de capital e renda da terra, este foi o componente mais importante na formação dos preços do fator em questão.

Brandão e Rezende (1989) realizaram um estudo quantitativo dos determinantes do preço de terra e de arrendamento, de 1966 a 1986, no Centro-Sul do Brasil ${ }^{8}$, observando as evidências e analisando as principais questões debatidas na literatura sobre o tema em questão.

Para tanto, analisaram fatores relacionados à conjuntura macroeconômica do país no período e também algumas variáveis de interesse agrícola. As variáveis macroeconômicas examinadas foram: taxa de inflação, crescimento do PIB per capita (observado através da proxy hiato do produto) e taxa de juros de mercado (tendo como

\footnotetext{
${ }^{8}$ Minas Gerais, Rio de Janeiro, São Paulo, Paraná, Santa Catarina, Rio Grande do Sul, Goiás, Mato Grosso do Sul e Mato Grosso
} 
proxy a correção monetária). As variáveis analisadas relacionadas à agricultura e à política agrícola foram: preço real da terra, valor real de arrendamento, subsídio ao crédito rural, montante de subsídio, taxa de juros do crédito rural, valor da produção agrícola e produtividade.

Os autores argumentaram que, além da queda na relação entre arrendamento e preço da terra e do acréscimo no volume de crédito concedido à agricultura, o decréscimo na taxa de juros atuante sobre o crédito agrícola foi também responsável pela hipótese de que o subsídio ao crédito rural fora capitalizado no preço da terra.

Desta forma, Brandão e Rezende (1989) levantaram as principais questões mencionadas na literatura que tentaram explicar o comportamento do mercado de aluguéis de terra sob o sistema de crédito rural subsidiado.

A primeira constatação foi a de que o acréscimo no volume de crédito concedido à agricultura e o decréscimo na taxa de juros atuante sobre esse crédito deixaram o valor do arrendamento inalterado. A hipótese é que, não havendo alterações de preços no mercado de fatores nem no mercado de produtos agrícolas, o crédito concedido não estaria sendo aplicado na agricultura, mas sim no mercado financeiro. Se a renda agrícola não variava, o valor do arrendamento também não deveria se alterar.

Esclareceram que mesmo se os arrendatários não tivessem acesso ao crédito, o arrendamento dependeria da estrutura do mercado de aluguéis de terra. Se a terra para arrendamento fosse ofertada predominantemente por fazendeiros que utilizaram o crédito e se o retorno marginal à terra utilizada por esses fazendeiros crescesse como resultado da política de crédito, então o nível de equilíbrio do preço do arrendamento também deveria subir, como sugerido por Rezende (1982a).

Como resultado dos testes econométricos, os autores obtiveram resposta não significativa da variável subsídio ao crédito rural em relação ao valor dos arrendamentos, mesmo tendo sido significativos o montante de crédito e a taxa de juro real do crédito rural sobre a variável em questão. 
Obtiveram resultados inesperados quanto à relação entre valor do arrendamento e preços recebidos pelos produtores e quanto à produtividade. Essas variáveis mostraram-se não significativas. Entretanto, o produto dessas duas variáveis (valor da produção agrícola/ha) apresentou coeficiente positivo. Tanto o valor do arrendamento quanto o preço da terra mostraram-se negativamente correlacionados com o Índice da Bolsa de Valores.

Um fato interessante levantado pelos autores é que na ausência de crédito rural subsidiado, a taxa de juros de mercado manteria uma relação inversa com os preços de terra, pois quanto maior essa taxa, maior seria a quantidade de recursos destinada ao mercado financeiro. Porém, em uma economia em que há a distorção pelo subsídio ao crédito rural, isso não se verifica. Uma taxa de juros de mercado mais alta equivale a um acréscimo no subsídio elevando, portanto, a demanda por terra. Esse fato é consistente com o observado pelos autores, tanto para o preço da terra quanto para o valor do arrendamento.

Os autores notaram ainda que a relação entre mercado de terras e mercado financeiro se torna mais complexa na presença da inflação. Existindo na economia um ativo perfeitamente indexável e com retorno real conhecido, este será preferível à terra para proteção contra a inflação. Assim, na presença desse ativo surge uma relação inversa entre inflação e preço da terra. Na ausência desse ativo, desde que os detentores de riqueza acreditem que a terra seja uma boa proteção contra a inflação, existirá uma relação direta entre o preço desse fator e a taxa de inflação. Os autores observaram essa relação direta entre taxa de inflação e preços de terra e de arrendamento.

Notaram uma correlação positiva entre o valor do arrendamento e o nível de atividade econômica, o mesmo tendo sido observado para este último e os preços de venda da terra. Esta última análise (relação positiva entre preço da terra e nível de atividade econômica) está de acordo com Pinheiro (1980), Pinheiro e Reydon (1981) e Castro (1981), porém, está oposta ao que foi notado por Rangel (2000), Rezende (1982a) e por Brandão (1986). 
Os preços de venda de terra apresentaram correlação positiva também com os preços recebidos pelos produtores, com a produtividade e com o subsídio ao crédito rural.

Os autores concluíram que os resultados por eles obtidos, ainda que muito preliminares, foram consistentes com a análise feita anteriormente. Colocaram algumas limitações sobre o estudo em questão, como a ausência da relação entre salários e quantidade de terra que os pequenos agricultores desejariam arrendar. Uma outra limitação seria a fixação da quantidade de terra disponível no sistema. É sabido que no período em análise houve significativo crescimento da quantidade de terra agricultável disponível, devido principalmente ao crescimento da infra-estrutura e das inovações agronômicas.

Ferreira e Camargo (1989), com o intuito de melhor entender a questão agrária brasileira, estudaram a formação dos preços de arrendamento de terras (pecuária e lavoura) no Brasil e em nível regional, no período de 1966 a 1986.

As autoras observaram taxas de crescimento anuais positivas tanto para o Brasil como para as regiões separadamente, no período em questão. Ao dividirem o período de análise em dois sub-períodos, notaram que os preços de arrendamento cresceram mais no período de 1966 a 1972 que no período de 1973 a 1986. Com relação aos preços do arrendamento entre semestres, notaram que não apresentaram diferenças significativas. As autoras encontraram altos coeficientes de correlação entre os diversos tipos de arrendamento, concluindo que o preço do arrendamento de uma determinada categoria está relacionado ao preço das demais.

Obtiveram também correlação positiva entre arrendamento para lavoura e preços recebidos pelos produtos agrícolas. Em se tratando do arrendamento para pecuária e o respectivo preço recebido pelos produtos animais, a correlação não só foi positiva como muito próxima de um. Disso concluíram que os preços de arrendamento estiveram diretamente relacionados com a evolução dos preços dos produtos agrícolas e pecuários. 
Concluindo, as autoras enfatizaram que as alterações nos preços de arrendamento no período de 1966 a 1986 são resultantes, basicamente, das variações nos preços dos produtos agrícolas e pecuários.

Reydon (1989) realizou um estudo levantando algumas questões teóricas sobre a formação do mercado de terras.

Para este autor, a renda da terra seria o excedente gerado durante o processo produtivo necessário para repor o adiantamento pago pela terra. O preço mínimo de venda da terra deveria ser igual à renda que ela poderia gerar. Porém, "na medida que essa terra, por suas características específicas, também é um elemento que conta com valorização autônoma no mercado de títulos, a demanda por este ativo acaba por sobredeterminar esse preço" (Reydon, 1989, p.423). A terra passa a ter, portanto, o seu preço determinado também por variáveis do mercado financeiro tais como: bolsa de valores e taxa de juro.

$\mathrm{O}$ autor salientou, entretanto, que as terras, para se transformarem em ativos, deveriam ter como requisito a possibilidade de adentrarem no processo produtivo e gerarem uma renda em um dado prazo econômico. Isto é, qualquer terra pode ser um ativo na medida em que o agente que o adquira tenha a expectativa de que esta adentre no processo produtivo. Assim, segundo o autor, o preço mínimo da terra seria a renda que ela proporciona. Todavia, deve-se ressaltar que a taxa de juro tem papel fundamental na determinação do preço da terra, fato que não é enfatizado por Reydon (1989). A formação do preço de venda da terra é dada pela razão entre o valor do arrendamento e a taxa de juro. Desta maneira, o preço mínimo de venda da terra deveria ser igual à renda que ela proporciona, capitalizada a uma determinada taxa de juro.

Camargo e Ferreira (1989), em seu estudo sobre o mercado de terras, buscaram analisar a evolução dos preços reais de terras de lavoura, pastagem, campos e matas no Brasil e nas regiões geográficas brasileiras, de 1966 a 1986. Procuraram verificar a tendência destes preços, as correlações existentes entre os preços das diversas categorias e sua relação com o valor de seus arrendamentos. Além disso, observaram também as 
relações entre os preços dos diferentes tipos de terra com alguns indicadores do mercado de capitais.

$\mathrm{Na}$ comparação feita pelas autoras entre os preços de terras de lavouras e alguns indicadores do mercado de capitais (Índice Geral de Preços - Disponibilidade Interna, Obrigações Reajustáveis do Tesouro Nacional, Taxa de Câmbio e Índice de Lucratividade da Bolsa de Valores de São Paulo), de 1966 a $1968^{9}$, observaram a clara predominância da rentabilidade da terra de lavoura e do Índice da Bolsa de Valores de São Paulo (em alguns anos, um supera o outro) sobre os demais indicadores, em boa parte do período analisado.

De 1966 a 1986, segundo essas autoras, terra de campos apresentou a maior valorização $(4,95 \%$ ao ano), seguida de terra para lavoura $(4,49 \%$ ao ano), erra para pastagens $(3,68 \%$ a.a.) e terra para matas $(2,72 \%$ a.a.). A provável causa da maior valorização de terras de pior qualidade, segundo as autoras, foi a procura de investimentos imobiliários por parte da população urbana, buscando beneficiar-se dos incentivos fiscais das políticas governamentais. Como existe alta relação entre os diferentes tipos de terra, o aumento na procura por um tipo de terra influenciou os preços dos demais. Além dos fatores apontados, essa maior valorização pode estar também relacionada ao avanço tecnológico da agricultura brasileira, com maior uso de insumos, como os fertilizantes.

As autoras notaram também que a variação de preços de terra nas diversas regiões brasileiras mostrou-se bastante desigual durante o período analisado, refletindo as diferentes estruturas produtiva e fundiária, a expansão da fronteira agrícola nas regiões Norte e Centro-Oeste, a escassez relativa de terras no Sudeste e Sul, os problemas climáticos no Nordeste, a diversidade de rendimentos físicos das culturas, além dos impactos causados pela desproporcionalidade do crescimento econômico nos estados.

\footnotetext{
${ }^{9}$ A comparação foi feita no período de 1966 a 1986, exceto para o índice BOVESPA que foi utilizado a partir de 1970
} 
Verificaram ainda que a taxa de crescimento dos preços reais dos diversos tipos de terra de 1966 a 1986 foi positiva e a diferença de preços entre semestres não foi significativa. Os coeficientes de correlação entre os preços das diversas categorias, entre preços de terra e preços de arrendamento foram elevados, assim como se apresentaram altamente correlacionados com alguns indicadores econômicos selecionados. Contudo, apesar do alto coeficiente de correlação verificado entre o preço real da terra e o valor do arrendamento, este último não cresceu tanto quanto o primeiro.

Segundo Camargo e Ferreira (1989), nas regiões Sul e Sudeste, onde é mais acentuada a escassez de terras de lavouras, foi maior o preço de venda de terra, refletindo justamente a menor oferta de terras da categoria citada. Contudo, alguns estados do Nordeste, com índices de ocupação mais elevados que os do Sul, possuíam terras mais baratas. Isso mostrou, segundo as autoras, que a produtividade que se pode extrair da terra é também importante na determinação de seu preço e não somente sua escassez. Analogamente, o preço da terra no Nordeste pôde ser visto como indício de forte disparidade tecnológica entre os diferentes estados.

Argumentaram que a veracidade desta afirmativa está na possibilidade de se adquirir terras a um preço muito baixo em regiões que estão longe de gerar uma produção agrícola compatível com os níveis médios de produção.

As autoras citaram alguns dos fatores que mais influenciaram na formação do preço da terra no Brasil. Entre eles estão: processo de urbanização, infra-estrutura disponível, distâncias dos centros consumidores, preços dos principais produtos agrícolas, crescimento demográfico, relações de troca agricultura/indústria, incentivos fiscais para penetração do capital industrial e financeiro no campo e a política econômica.

Bacha (1989) elaborou um estudo com o intuito de desenvolver modelos estatísticos que explicassem a determinação dos preços de venda e de aluguel da terra na agricultura brasileira. Para tanto, selecionou variáveis a fim de explicar o comportamento desses preços na agricultura mineira, de 1970 a 1985. Para formular seu 
modelo, baseou-se na concepção de que esses preços são estabelecidos no cruzamento entre oferta e demanda de terra para venda e para aluguel.

O autor separou os donos de terra em duas categorias, segundo a relação do indivíduo com o fator de produção: proprietários agricultores e proprietários especuladores. Os primeiros demandam terra conforme as condições de lucratividade da atividade agrícola. Já as variáveis de interesse para os proprietários especuladores são: valorização da terra, rentabilidade de aplicações financeiras e incerteza sobre a estabilidade inflacionária.

Um fato curioso com relação à posse da terra para fins de especulação, segundo o autor, é que há a probabilidade de que uma parcela das terras adquiridas, para fins especulativos, não seja ofertada para arrendamento. $\mathrm{O}$ argumento é que essas terras devem estar disponíveis para venda no momento adequado para tal, o que não aconteceria caso estivessem arrendadas. Portanto, os especuladores que porventura realizassem algum investimento agropecuário em seu estabelecimento fariam-no somente com o objetivo de valorização patrimonial, e não com o objetivo agropecuário.

Bacha (1989) estabeleceu algumas hipóteses sobre o comportamento dos agentes quanto à demanda e oferta de terra. Enquanto predominar o baixo rendimento real no mercado financeiro, a demanda por terra para fins especulativos será alta. Por conseguinte, a oferta de terra para arrendamento é menor. Ao contrário, havendo melhora no rendimento dos papéis financeiros, há interesse em se migrar em busca dessa rentabilidade. Assim, aumenta a oferta de terra para arrendamento ${ }^{10}$.

Seguindo essa hipótese, o autor estabeleceu um equilíbrio entre oferta e demanda de terra para arrendamento, resolvendo a igualdade e obtendo os resultados para a variável endógena preço de terra para arrendamento. As variáveis explicativas selecionadas para tal análise foram: disponibilidade total de terra para a atividade agrícola, preços dos produtos agrícolas em relação ao preço dos insumos agrícolas, taxa

\footnotetext{
${ }^{10}$ Essa hipótese levantada pelo autor baseia-se nos estudos de Egler (1985).
} 
de juro real das aplicações financeiras, preço real de arrendamento, taxa de juros real do crédito rural, preço real dos insumos modernos e nível tecnológico.

Ao analisar o mercado de terra para venda, o autor chamou a atenção para o fato de ser uma demanda com fins produtivos e especulativos. Assim, para determinar o equilíbrio entre oferta e demanda, considerou as seguintes variáveis: disponibilidade total de área agricultável, taxa de juro real dos ativos financeiros, taxa de juros do crédito rural, preços dos produtos agrícolas em relação aos preços dos insumos agrícolas, preço de mercado da terra, avanço tecnológico, preço real dos insumos modernos, variável binária para captar o efeito do novo ITR a partir de 1980, taxa de inflação e taxa de crescimento da economia.

Através dos resultados obtidos, o autor observou um predomínio das variáveis ligadas ao setor agrícola (preços reais dos insumos modernos, nível tecnológico e relação entre preços recebidos pelos produtores e preços pagos pelos produtores) em relação aos componentes especulativos ou aos elementos ligados ao ambiente econômico, tanto na determinação do preço real de arrendamento como na determinação do preço real de venda da terra.

Brandão (1992) revisou os principais trabalhos existentes sobre o comportamento do preço da terra no Brasil ${ }^{11}$, de 1966 a 1984, analisando a evidência empírica existente. Em seguida, observou a tendência de evolução do preço, do aluguel e da rentabilidade das terras para lavoura e pecuária, sistematizando os principais fatos. Além disso, comparou a rentabilidade da terra com a de outros ativos (cadernetas de poupança, letra de câmbio, dólar no mercado oficial, dólar no mercado paralelo e ações) e mostrou que a terra como um todo (rentabilidade propriamente dita e ganho de capital) apresentou-se como um ativo bastante atraente ao longo do período analisado, com risco relativamente baixo e retorno médio relativamente elevado. $\mathrm{O}$ autor estimou ainda

${ }^{11} \mathrm{O}$ autor estimou regressões lineares múltiplas para cada um dos estados do Centro-Sul: Minas Gerais, Espírito Santo, Rio de Janeiro, São Paulo, Paraná, Santa Catarina e Rio Grande do Sul, tendo em vista a maior precisão dos dados nesses estados. 
regressões entre o preço e o aluguel da terra de lavoura e de pecuária e algumas variáveis mencionadas na literatura.

Brandão (1992) observou que em todo o período da análise, o preço da terra de lavoura esteve em patamar superior ao preço da terra de pastagem, além de ter tido também um crescimento superior ao preço da terra desta última categoria. Isso significa que ao lado dos elementos comuns, fatores específicos atuaram sobre cada um dos segmentos do setor agrícola, induzindo a uma acentuada diferenciação nos preços desses dois tipos de terra. $\mathrm{O}$ autor complementou ainda que essa diferença de qualidade do solo deveria explicar um diferencial praticamente constante nesses preços, diferentemente do que mostraram os dados que ele utilizou na pesquisa.

A relação entre aluguel e preço de terra de lavoura e pecuária foi também objeto de análise no estudo em questão. $\mathrm{O}$ autor chamou a atenção para o descolamento entre essas duas variáveis a partir de 1976/77, principalmente no caso da pecuária. Uma provável causa da queda na relação aluguel/preço da terra, conforme a literatura, seria a interferência de fatores externos ao setor agrícola na determinação dos preços de terra, como o crédito rural subsidiado.

Ao desmembrar o rendimento de terras para lavoura e para pastagem em ganho de capital e rendimento propriamente dito ${ }^{12}$, o autor notou que somente em alguns anos o primeiro componente superou este último. Notavelmente, estes anos coincidiram com os picos de preços observados no início da década de 70 e com alguns casos esporádicos nos anos 80.

\footnotetext{
${ }^{12}$ Rendimento $=\frac{[p(t)+d(t)]}{p(t-1)}$, sendo $p(t)$ e $d(t)$ preço e o aluguel da terra respectivamente, no período $t$.$$
\text { Ganho de capital }=\left\{\left[\frac{p(t)}{p(t-1)}\right]-1\right\} \times 100
$$$$
\text { Rendimento propriamente dito }=\left[\frac{d(t)}{p(t-1)}\right] \times 100
$$ 
O valor médio do rendimento foi muito superior ao do ganho de capital para os dois tipos de terra, em todo o período de análise. O coeficiente de variação e a média dos ganhos de capital, em relação aos demais ativos financeiros considerados no estudo, mostraram que a terra constituiu-se num ativo de rentabilidade pouco atrativo, especialmente pelo alto risco associado. Desta forma, o autor argumentou que dificilmente os possuidores de terra buscassem apenas ganhos de capital. Quando considerada como um todo (ganhos de capital e rendimento propriamente dito), a terra mostrou-se capaz de competir com as demais alternativas existentes no mercado financeiro.

Dos resultados obtidos com as regressões, o autor concluiu que a variável crédito rural foi a mais importante tanto para os preços quanto para o aluguel de terras, tanto para lavouras quanto para pastagens. Mostrou-se significativa e com coeficientes positivos em ambos os casos. Contudo, o autor notou diferença nas elasticidades estimadas entre preço e aluguel de terra. Os coeficientes obtidos foram maiores para os primeiros do que para os últimos, assim como foram maiores para terra de lavouras que para terra de pastagem. As variáveis explicativas utilizadas para representar o ciclo econômico e a rentabilidade da atividade (hiato do produto e relação entre preço recebido e preço pago, respectivamente) não apresentaram resultados satisfatórios e condizentes com as hipóteses formuladas.

Na última parte do trabalho, Brandão (1992) apresentou um instrumental de análise a fim de discutir as relações entre o mercado de terras e as mudanças na estrutura fundiária. Notou que a política agrícola então existente no Brasil, composta não somente pelo crédito rural subsidiado mas também por incentivos fiscais para investimento agrícola e para gastos com insumos modernos, talvez fosse um dos maiores empecilhos à tentativa de reforma agrária na época. Tal política induzia à elevação dos preços da terra (elevação dos ganhos de capital) e, conseqüentemente, tornava o ativo inacessível a agentes pobres. Aqueles indivíduos que já o possuíssem poderiam ser levados a se desfazer do fator a fim de obterem o ganho adicional associado. 
Romeiro e Reydon (1994) fizeram uma revisão detalhada dos principais estudos sobre o mercado de terras, discutindo a veracidade de algumas das hipóteses.

Assim, discordaram de Egler (1985) quando este sugeriu que a demanda por terras tanto urbanas quanto agrícolas seria determinada pelo comportamento da taxa de juros estabelecida no mercado financeiro. Romeiro e Reydon (1994) discutiram essa análise alegando que empiricamente obtiveram diferentes conclusões. Estes autores argumentaram que, em diferentes momentos da agricultura brasileira, os determinantes do preço da terra eram distintos, e iam além da taxa de juros. Dentre eles, havia o caráter produtivo vinculado à própria agricultura, como em 1984 e 1985 quando houve expressiva elevação da quantidade de produtos agrícolas exportáveis, acarretando aumento do preço da terra em regiões que exploravam tais produtos.

Sayad (1982) concluiu que decidir comprar terra, um agente leva em consideração as possibilidades de ganho com a especulação com a mesma e as condições lucrativas associadas à produção agrícola. Entretanto, a decisão de compra se dá quando o indivíduo compara a taxa de retorno da terra (que inclui os seus ganhos produtivos e especulativos) com uma taxa média de retorno da economia. Assim, o mercado financeiro é quem acabaria determinando a demanda por terras e, portanto, o preço delas. Romeiro e Reydon (1994), contudo, não observaram este caráter anticíclico dos preços da terra. Contrariamente, notaram que os preços da terra acompanharam o movimento mais geral da economia, caracterizando um movimento pró-cíclico, assim como Castro (1981), Brandão e Rezende (1989) também o fizeram.

Assim, Romeiro e Reydon (1994) finalizaram sua revisão concluindo que todos os estudos analisados apresentaram deficiências, o que dificultou a identificação das características que determinam o preço da terra. Concluíram que todos os autores analisaram o mercado nacional de terras utilizando somente determinantes gerais dos preços desse fator, esquecendo dos determinantes específicos de cada região. Neste sentido, características regionais que poderiam interferir significativamente na determinação do preço da terra (até mesmo em nível nacional) não foram consideradas. 
Monteiro (1995) analisou o comportamento dos preços de terra do segundo semestre de 1992 ao primeiro semestre de 1995. A autora teve o intuito de analisar esse mercado sob o efeito da estabilização advinda do Plano Real.

Tendo em vista a conjuntura do período, o Plano Real poderia provocar dois comportamentos nos preços da terra: uma vez consolidada a estabilização, deveria ocorrer maior interesse por atividades produtivas, aumentando a demanda por terra e causando a elevação de seu preço; ou então, haveria a queda de atratividade da terra como reserva de valor, uma vez que a economia estava estável e portanto, seu preço diminuiria.

Com a entrada desse Plano, os preços recebidos pelos produtores caíram demasiadamente. Muitos agricultores ficaram endividados e foram forçados a vender terra para saldar compromissos financeiros. Essa baixa rentabilidade do setor causou desestímulo a novos empreendimentos e, conseqüentemente, a demanda por terra foi bastante reduzida. As altas taxas de juros vigentes no período diminuíram o interesse especulativo por terra como reserva de valor.

Monteiro (1995) ressaltou ainda a associação entre o movimento dos valores da terra e os vários planos de estabilização da economia. Argumentou que os preços de terra elevaram-se tanto em momentos de ascensão dos preços agrícolas (Plano Cruzado) como em momentos de queda desses preços (Plano Real).

Ferreira Filho (1999), em sua pesquisa sobre os desafios da estabilização econômica para a agricultura brasileira, quis apresentar algumas reflexões sobre as implicações trazidas pela estabilização para a agricultura brasileira. Além disso, abordou algumas consequiências da queda da inflação e das políticas associadas ao Plano Real sobre a estrutura de custos (e estrutura patrimonial) da agricultura.

Segundo o autor, a queda da inflação advinda da implantação do plano Real gerou muitos efeitos benéficos para a agricultura. A melhora no horizonte de planejamento da produção, devido à redução de risco de preços inerente ao processo 
inflacionário, é um deles, tendo em vista o longo tempo que decorre entre a decisão de se produzir e o momento em que a produção chega aos mercados.

Porém, um efeito negativo particular caiu sobre a agricultura a despeito da estabilidade da economia: a queda do valor dos ativos reais, por causa da perda de reserva de valor. Como se sabe, há o endividamento de uma parcela da agricultura brasileira, que originou-se no Plano Collor. Com a queda dos preços das terras houve um aumento da disparidade entre o valor dos passivos dos agricultores e seus ativos. Enquanto o valor dos primeiros continuou a ser corrigido de acordo com a inflação, o valor dos ativos teve forte queda, conforme discutido aqui. Como resultado, em boa parte dos casos os ativos que lastreavam as dívidas desses agricultores já não eram suficientes. Ferreira Filho (1999), concluiu, então, que para as instituições financeiras seria difícil tanto a rolagem da dívida como a sua execução.

Por outro lado, a queda nos preços de terras agrícolas facilita o seu acesso, o que poderia ser um argumento a favor da agricultura. Porém, empiricamente isso não ocorreu. Com a entrada do Plano Real e a valorização cambial, os insumos agrícolas tornaram-se mais baratos. Com isto, a relação de trocas entre terras agrícolas e tratores e fertilizantes elevou-se no período pós-estabilização, ou seja, a terra tornou-se mais cara, em termos relativos, do que aqueles insumos produtivos. A terra tornou-se um fator mais barato, em termos absolutos, porém mais cara em termos relativos, o que pode estar relacionado com a queda na área cultivada, observada no período.

Reydon e Plata (2000) caracterizaram a terra como sendo um ativo de capital e como ativo líquido simultaneamente. Ativo de capital pois é utilizada para produzir outros bens, apesar de ter oferta fixa. Ativo líquido porque tem um mercado secundário estabelecido e é relativamente fácil desfazer-se da terra, quando desejado. É negociada em uma estrutura de mercado flexível, e seu preço é determinado dependendo das expectativas de ganhos futuros do comprador e do vendedor, com o uso da terra.

Para esses autores, o preço da terra rural reflete os ganhos esperados para os quatro seguintes atributos capitalizados: 


$$
P=q-c+l+a
$$

em que:

$q$ representa as quase-rendas produtivas. Essa variável está intimamente ligada aos ganhos produtivos com a terra. Nela estão embutidos desde ganhos com a produção agrícola até crédito e subsídios governamentais.

$c$ representa o custo de manutenção. São todos os custos não produtivos da terra. Entre eles: impostos, custos de transação, etc.

$l$ representa o prêmio de liquidez da terra. Está associado à facilidade de venda da terra no futuro e depende, portanto, das expectativas sobre o futuro. Quando a economia está crescendo, aumenta a demanda por recursos produtivos, fazendo com que $l$ cresça. Porém, pode também crescer quando há aumento na demanda por ativos líquidos e as expectativas do comportamento de outros ativos líquidos não são tão promissoras quanto às da terra.

a representa o ganho patrimonial da terra. Como exemplo de compradores exclusivamente interessados nesse ganho podem-se citar aqueles que adquirem terras na fronteira. Essas áreas não apresentam rendimento produtivo em um prazo econômico e o objetivo da aquisição é unicamente obter ganhos na revenda.

Há, todavia, uma crítica a ser feita com relação à expressão de determinação do preço da terra proposta por Reydon e Plata (2000). O preço de venda da terra deve expressar, no mínimo, a relação entre as quase-rendas produtivas e a taxa de juro, assim como no estudo de Reydon (1989). Ao desconsiderar a taxa de juro como um dos fatores formadores do preço da terra, a expressão descrita anteriormente não determina o real preço deste fator.

Os autores levantaram a questão de que nem sempre o preço da terra será igual ao valor presente dos fluxos de receitas líquidas futuras, pois podem existir fatores que afetem o preço de mercado e que não alterem a medida de valor presente. $\mathrm{O}$ método do 
valor presente leva em consideração somente as medidas de longo prazo: expectativas de ganhos produtivos e custos de manutenção da terra. Sob essa hipótese, as variáveis de curto prazo associadas à liquidez da terra estariam ausentes da análise. Com esse argumento, discordaram daquele levantado por Reinsel e Reinsel (1979).

Os indivíduos que desejam comprar terras estão interessados em todas as rendas que a terra pode gerar, ou seja, tanto a renda produtiva quanto a renda gerada pela liquidez da terra. De outro lado, o indivíduo que pretende arrendar terra está disposto a pagar um aluguel baseado apenas nas rendas produtivas da terra.

Os autores levantaram diversos fatores que afetam os preços da terra, os quais estão inseridos nas variáveis acima especificadas. Discutiram os efeitos de cada um dos fatores sobre $q, c, l$ e conseqüentemente, sobre os preços da terra.

Primeiramente, a demanda por terras para a atividade agropecuária é determinada pelo preço do bem nela produzido e pelas condições de produção, tais como: tecnologia, custo de insumos e outros fatores relacionados à produção. Ainda associadas à terra como capital produtivo estão as expectativas de elevação no preço do produto e de redução nos custos de produção. A infra-estrutura existente é também um fator de extrema importância para o lado produtivo da terra. A existência de mercado consumidor próximo, acesso à água e informações e facilidade de transporte podem aumentar o preço da terra e são fatores de diferenciação nos preços locais.

Um outro fator mencionado pelos autores é o crescimento populacional, que pode exercer influência altista nos preços de terra de duas maneiras: aumentando a demanda por alimentos e pressionando a urbanização.

A inflação também pode influenciar os preços de terra de duas formas: primeiramente afetando a estrutura de preços (preços dos produtos e dos insumos) associada à quase-renda. Pode também estar relacionada com a liquidez da terra, que passa a ser utilizada como reserva de valor. Os autores apontaram ainda o efeito da inflação sobre as taxas de juros reais da economia. Num contexto inflacionário, em que 
as taxas de juros reais são negativas, os ativos financeiros não são investimentos atrativos e os indivíduos passam a procurar outros ativos reais como a terra. Ressaltaram que o valor do arrendamento da terra para produção agrícola, em períodos inflacionários, deve ser afetado somente por variações nos preços dos insumos e dos produtos e não pela utilização da terra como reserva de valor.

Os autores defenderam a tributação sobre terras para estimular o uso produtivo daquelas subutilizadas ou ociosas. Argumentaram que a tributação faz com que haja um aumento dos custos de manutenção da terra, diminuindo as vantagens ao especulador que pretende obter ganhos com a simples posse da terra. Além disso, quando aumentam os custos de manutenção ocorre uma diminuição do preço da terra, possibilitando seu uso produtivo. Sayad (1977b) também idealizou algo próximo ao sugerir a taxação dos ganhos de capitais com a finalidade, porém, de desenvolver o mercado financeiro.

Os altos custos de transação no Brasil são argumentos a favor da baixa demanda por terras. Esse desincentivo incorre em dois efeitos: não permite a distribuição da terra para seu melhor uso econômico e diminui a sua demanda para fins especulativos.

O sistema financeiro nacional pouco desenvolvido traz dois efeitos opostos ao mercado de terras. Aumenta a demanda por terras como investimento de longo prazo, como ativo líquido, elevando o preço delas. Por outro lado, desincentiva o acesso ao mercado (de terras), pois não proporciona financiamento de longo prazo a juros mais baixos.

Um último determinante do preço da terra levantado pelos autores é o ambiente socioeconômico no qual o fator de produção está inserido. Nesse ambiente encontram-se as demais alternativas de investimento, o sistema legal, risco de invasões oferecido pela propriedade, etc. 
A seguir, os autores mostraram a evolução dos preços da terra no Brasil e tentaram explicar cada momento segundo os determinantes acima explicitados. Foca-se, no trabalho desses autores, o mercado de terras após a entrada do Plano Real.

O cenário macroeconômico do período em questão diminuiu os preços de terra por dois motivos: altas taxas de juros e queda da inflação. Com as taxas de juros altas os investimentos na produção tornaram-se menos rentáveis, reduzindo os preços da terra. De outro lado, a queda da inflação fez com que a terra perdesse seu atrativo como reserva de valor e como ativo especulativo, reduzindo seu preço. Assim, com a entrada do Plano Real, tanto as expectativas de ganhos produtivos quanto de ganhos especulativos têm diminuído, reduzindo, portanto, a demanda por terra e seu respectivo preço.

Por fim, mencionaram que a desvalorização da taxa de câmbio pode levar a aumentos de preços de terra em locais onde a agricultura seja voltada à exportação.

Helfand e Rezende (2001) observaram a existência de uma relação competitiva entre ativos agrícolas (terra, gado e commodities) e ativos financeiros, em épocas de instabilidade macroeconômica, principalmente nas fases de implantação dos planos de estabilização.

Tanto o Plano Cruzado (1986) como o Plano Verão (1989) e Planos Collor I e II (1990 e 1991, respectivamente) ao serem implementados, causaram elevação nos preços dos ativos agrícolas, uma vez que os ativos financeiros tiveram sua rentabilidade diminuída. Quando tais planos fracassaram, os ativos financeiros voltaram a ser rentáveis levando, conseqüentemente, à queda dos preços de ativos agrícolas.

Um fato interessante é que na implantação do Plano Real (início de 1994, com a instituição da Unidade Real de Valor), a mesma euforia sucedeu-se no mercado agrícola, levando à elevação nos preços dos ativos desse mercado. Entretanto, tais preços recuaram no final de 1994 e início de 1995, mesmo com o sucesso do Plano, graças às 
taxas de juros extremamente altas que fizeram com que os recursos migrassem para ativos financeiros.

Nota-se, portanto, que a insegurança na implantação de planos de estabilização foi um dos motivos que levaram indivíduos a procurar terras (e outros ativos agrícolas). Outro fator que determinou a elevação dos preços da terra nas fases previamente mencionadas foi a rentabilidade de ativos financeiros vis a vis de ativos agrícolas.

Dias, Vieira e Amaral (2001) elaboraram uma pesquisa sobre o mercado de terras no Brasil com o intuito de investigar se esse mercado tem sido uma barreira para o crescimento agrícola ou para o progresso tecnológico na agricultura.

Através de uma pesquisa de campo no estado do Rio Grande do Norte, no ano de 1999, buscaram também verificar os motivos causadores da diferença no preço da terra em diferentes regiões desse estado. Como resultado, observaram que essa diferença estava na acessibilidade ao mercado, na fertilidade natural do solo ou na facilidade de acesso à água para irrigação. Se o indivíduo pagava um preço mais baixo por uma terra menos fértil, o diferencial entre essa terra e uma outra mais fértil, porém igualmente próxima ao mercado, seria dado pela menor produtividade da primeira. O mesmo ocorreria para terras de mesma fertilidade e com distâncias diferentes do mercado. Esses são os efeitos da renda diferencial.

Em primeira instância notaram que um dos motivos que explicavam a baixa utilização da terra como fator de produção, no Brasil, foi o histórico de concentração fundiária. Essa concentração também gerou preços positivos para a terra, mesmo em condições de oferta abundante. Com expectativas de ganhos de capital advindas de investimento em infra-estrutura e do crédito subsidiado, os grandes proprietários controlavam a oferta de terras, gerando, portanto, uma demanda por reserva. Restringiam a oferta de terras principalmente em épocas de instabilidade econômica. Quando a crise econômica amenizava-se e os preços de terra ainda estavam altos, ofertavam terras, levando a uma diminuição do preço delas. Notaram, portanto, a relação entre preço de terra e a variável macroeconômica. 
Os autores levantaram os principais fatores responsáveis pela variação dos preços da terra em cada década. A década de 60 foi marcada por variáveis que amenizaram a demanda por terras, tais como choques tecnológicos, aumentos de produtividade e também por aquelas que estimulavam a demanda por esse fator, como investimento em infra-estrutura e crédito subsidiado.

$\mathrm{Na}$ década de 70, diversos foram os fatores relacionados ao preço da terra levantados pelos autores, que estimularam sua elevação, como o crédito rural subsidiado e o aumento de produtividade. A política de crédito rural subsidiada contribuiu para elevar os preços da terra por dois motivos: primeiro porque era a garantia preferida pelos bancos para a concessão do empréstimo e segundo porque promoveu a modernização e aumentou a produtividade agrícola e o conseqüente aumento de rentabilidade do setor. Ressaltaram ainda que o modelo de crédito subsidiado esgotou-se no final da década de 70, passando a surtir pouco efeito sobre os preços da terra. Esse esgotamento deveu-se ao fato de as principais mudanças tecnológicas já terem sido incorporadas, ao esgotamento da expansão de fronteiras e ao início de uma nova fase de produção, com uso intensivo da terra. Assim como o crédito rural subsidiado, o aumento de produtividade estimulado pelo progresso tecnológico foi um fator que elevou e sustentou o preço real da terra nesse período.

Um terceiro fator levantado pelos autores, relacionado à elevação dos preços da terra nessa década, foi o período chamado de "milagre brasileiro", quando a economia do país experimentou um crescimento acelerado, de acordo com Pinheiro (1980), Castro (1981), Pinheiro e Reydon (1981), Brandão e Rezende (1989) e Romeiro e Reydon (1994). Os aumentos de infra-estrutura de estradas e de serviços públicos também contribuíram para a elevação dos preços da terra.

Nos anos 80 e 90, variáveis como grandes flutuações econômicas, preços relativos (recebidos e pagos pelos agricultores), índices de produtividade agrícola, taxas de juros e a instabilidade econômica medida pelos índices inflacionários deram o tom nas variações de preço da terra. Os autores lembraram também que entre meados dos anos 80 e 90 houve muita variação dos preços da terra por motivos especulativos, dada a 
incerteza quanto aos planos de combate à inflação, assim como também observaram Helfand e Rezende (2001). Com o fim da inflação e com a estabilidade econômica, os grandes proprietários sofreram perdas de capital com atitudes especulativas e a rigidez na oferta de terras deixou de ser importante.

A seguir, os autores conduziram um estudo mais aprofundado sobre a influência das variáveis levantadas na literatura para a determinação do preço real de terras no Brasil. Para tanto, utilizaram o preço da terra como variável dependente e como variáveis explicativas, as microeconômicas, tais como: índice de preços recebidos pelos agricultores, índice de preços pagos pelos agricultores, crédito rural, índice de produtividade. As macroeconômicas foram: hiato do produto e taxa de inflação. Como resultado encontraram sinais positivos para todas as variáveis.

Quanto à relação de preços (preços recebidos/preços pagos pelos agricultores), os autores obtiveram melhores resultados ao separar esses dois índices, visto que podem explicar fenômenos diferentes. Encontraram elasticidade unitária para ambas as variáveis. É fácil aceitar o resultado obtido para o índice de preços recebidos pelos agricultores. No entanto, para a segunda variável é necessário uma explanação melhor. $\mathrm{O}$ fato de os preços pagos pelos agricultores estarem positivamente relacionados com o preço da terra deve-se principalmente aos componentes de alta tecnologia incluídos nesse índice. Assim, surge um efeito substituição entre o fator terra e os fatores embutidos no índice em questão, na medida em que esses últimos são poupadores de terra. Quanto maiores forem os preços dos insumos substitutos da erra, maior será a demanda por terra e, portanto, maior o seu preço.

Apesar da relação positiva e significativa entre crédito rural e preço real da terra, a elasticidade obtida foi baixa. Uma explicação para tal fato foi a presença de multicolinearidade entre essa variável e o índice de preços pagos pelos agricultores.

Os autores encontraram um valor unitário para a elasticidade-produtividade do preço da terra. Há dois pontos a serem levantados com relação ao efeito da produtividade sobre os preços da terra: 1) a maior produtividade leva ao maior retorno 
de capital investido no fator e, portanto, maior demanda por terra; 2) com o aumento da produtividade há uma diminuição da demanda por terras; conseqüentemente, ocorre a redução do preço do fator, visto que são substitutos. Os autores ressaltaram essa observação e argumentaram que o valor unitário da elasticidade-produtividade do preço da terra é o resultado líquido no qual predomina a rentabilidade do fator.

O efeito positivo do hiato do produto sobre o preço da terra confirmou a hipótese dos autores Sayad (1977b), Rangel (2000), Rezende (1982), Brandão (1986) e Dias, Vieira e Amaral (2001): quando a economia entra em recessão, há uma elevação nos preços de terra, ocorrendo o contrário quando a economia volta a crescer.

Quanto à taxa de inflação, os autores encontraram resultado positivo e significativo, de acordo com o resultado também obtido por Brandão e Rezende (1989). Os autores sugeriram que se deve discutir qual o deflator mais apropriado para a análise dos determinantes do preço da terra, visto que "há razões para se acreditar que o preço da terra não tenha mostrado qualquer tendência de crescimento ou declínio nas décadas de 80 e 90" (Dias, Vieira e Amaral., 2001, p.62). Ressaltaram não saber se o preço da terra cresceria para os agricultores que considerassem a terra como fator de produção (sendo apropriado utilizar-se para tal o índice de preços pagos pelo produtor) ou se cresceria para outros agentes que considerassem a terra como reserva de valor (utilizando-se, então, o índice geral de preços para deflacionar o preço real da terra).

Um dos motivos pelo qual o preço da terra não mostrou tendência crescente no início da década de 80 foi a tecnologia implantada no setor agrícola, que valorizava mais o capital humano e o capital produtivo, substitutos de terra.

Além da aparente queda nos preços reais de terra, um outro fato marcante da década de 90 foi a mudança de preços relativos. Houve uma queda de quase cinqüenta por cento nos preços recebidos pelos agricultores em relação aos preços do setor urbano da economia. Os insumos agrícolas de origem industrial também tiveram seus preços reduzidos, graças à liberação comercial, o que preservou ou mesmo aumentou a 
rentabilidade do setor moderno da agricultura, que mostrou elevados ganhos de produtividade.

Embora o valor da terra em relação ao resto da economia tenha caído bastante, a relação preço da terra/preço do insumo não se alterou para o produtor com tecnologia moderna. Quem perdeu com a queda no valor da terra foi o tradicional dono de grandes propriedades fundiárias pouco produtivas (principalmente aqueles que entraram na década de 90 com dívidas contraídas em taxas de juros e correção monetária) e o pequeno produtor familiar de tecnologia tradicional (que sofreu com a queda dos preços dos produtos agrícolas e com as altas taxas de juros).

Finalizaram seu estudo concluindo que a demanda por terra é muito menos limitante hoje para a atividade agrícola do que fora no passado. Nas palavras dos autores: "a matriz tecnológica na agricultura mudou e a captação de renda não é mais dominada pela propriedade da terra, mas pelo custo relativo dos insumos e pela habilidade relativa dos controladores desta tecnologia que depende da mão-de-obra treinada, com custo de oportunidade dado pelo mercado e não pela vontade do poder 'terrateniente"'. (Dias, Vieira e Amaral, 2001, p.70)

Rezende (2002) estudou a estrutura agrária no cerrado brasileiro e trouxe algumas conclusões interessantes, principalmente no que se refere ao preço da terra nessa região. Além de sugerir alguns fatores determinantes para que o preço da terra no cerrado fosse mais baixo que nas regiões do Centro-Sul, elaborou um modelo de determinação do preço da terra de cultura de primeira (terra de melhor qualidade) e de segunda (terra de qualidade inferior à de primeira) para o cerrado brasileiro.

Os preços de terra de lavoura no Mato Grosso chegaram a ser, segundo o autor, 4 a 6 vezes menores que os preços de terra de mesma qualidade em São Paulo e no Paraná, no período de 1977 a 2000. Rezende (2002) mencionou que tal diferencial de preços pode ser explicado, em parte, por algumas características relacionadas aos recursos naturais daquela região (tais restrições de recursos são, principalmente, baixa fertilidade natural e baixíssima precipitação no período de abril a setembro). Além disso, 
a distância dos centros consumidores e a baixa pressão de ocupação para fins nãoagrícolas contribuem para justificar tal diferencial de preços. Uma quarta razão para os baixos preços de terra no cerrado estaria associada à inovação tecnológica, mais especificamente ao que o autor chamou de "produção do solo", que consiste na transformação de terras de qualidade inferior em terras de cultura de primeira.

O modelo de "produção de terra" elaborado por Rezende (2002) considera dois tipos de terra: a de cultura de primeira e a de segunda. $\mathrm{O}$ modelo supõe que o equilíbrio entre a demanda e a oferta pelos serviços da terra determina o valor do seu aluguel (qualquer que seja ela: de primeira ou de segunda). Por sua vez, o valor do aluguel, ao ser capitalizado a uma taxa de juros $i$, determina o preço da terra. O preço da terra poderia variar no curto prazo em função de expectativas otimistas ou pessimistas sobre o mercado financeiro, conforme notaram Reydon e Plata (2000) e Helfand e Rezende (2001), mas o autor ressalta que este fato está sendo desprezado em seu estudo.

A grande diferença trazida pelo modelo em questão é que existe a possibilidade de a terra de segunda ser transformada em terra de primeira, mediante o custo para assim torná-la. Sendo isso verdadeiro, a transformação de terra de segunda em terra de primeira aumentaria a oferta da terra de melhor qualidade, reduzindo, conseqüentemente, seu preço.

A sistematização do modelo, segundo Rezende (2002), se dá da seguinte forma:

$$
\begin{aligned}
& L_{1 t}^{d}=L_{1 t}^{d}\left(\begin{array}{c}
(-) \\
r_{1 t}, \ldots
\end{array}\right) \\
& L_{1 t}^{d}=k \times S_{1 t} \\
& L_{1 t}^{d}=L_{1 t}^{s} \\
& p_{1 t}=p_{1 t}\left(\begin{array}{cc}
(+) & (+) \\
r_{1 t}, i, \ldots
\end{array}\right)
\end{aligned}
$$




$$
S_{1(t+1)}=S_{1 t}+\Delta S\left(p_{1 t}-p_{2 t}, c_{1 t}\right)
$$

em que:

$L_{1 t}^{d}=$ quantidade demandada de serviços de terra de primeira no ano $t$;

$L_{1 t}^{s}=$ quantidade ofertada de serviços de terra de primeira no ano $t$;

$k=$ constante de proporcionalidade (converte unidade de estoque em unidade de serviços);

$S_{1 t}=$ estoque existente de terra de primeira em $t$;

$r_{1 t}=$ valor de aluguel de terra de primeira

$p_{1 t}=$ valor de venda (por hectare) de uma unidade de estoque de terra de primeira;

$i=$ taxa de juro real (custo de oportunidade de reter terra como ativo);

$p_{2 t}=$ valor de venda de uma unidade de estoque de terra de segunda;

$\Delta S_{1 t}=$ taxa de incorporação de nova terra de primeira em $t$;

$c_{1 t}=$ custo para se transformar uma unidade de terra de segunda em uma unidade de terra de primeira.

Assim, enquanto $p_{1 t}>p_{2 t}+c_{1 t}$, é viável "produzir" terra de cultura de primeira e $\Delta S_{1 t}$ é, portanto, positivo. Ao expandir a quantidade de terra de cultura de primeira, o valor de seu aluguel e conseqüentemente seu preço, caem. Isso ocorre até que se atinja um equilíbrio no qual $p_{1 t} \leq p_{2 t}+c_{1 t}$, que seria um equilíbrio estável de longo prazo. 
O mesmo ocorre no caso da erra de cultura de segunda. Há, entretanto, uma diferença com relação à primeira: a terra de pior qualidade é um "input" na função de produção da primeira. Assim, o preço da terra de primeira encontra-se “ 'ancorado' no preço da terra de segunda e no custo de conversão de uma terra em outra", nas palavras do autor (Rezende, 2002, p.16). A terra de segunda será função do preço da terra de mata mais os custos para a sua transformação. Segue a mesma idéia da terra de cultura de primeira.

É interessante notar que esse modelo aplica-se ao cerrado pois, nessa região, ainda há muita terra agricultável a ser incorporada ao processo produtivo, diferentemente do que acontece em outros estados como, por exemplo, o de São Paulo. Dos 204 milhões de hectares de cerrado brasileiro, somente 61 milhões são utilizados atualmente. Dado que 77 milhões de hectares são impróprios para a prática agrícola, ainda sobram 66 milhões que podem ser incorporados à atividade agrícola. Desta forma, o modelo sugerido é válido para a região estudada pelo autor mas não necessariamente para outras regiões.

Sumariando, vários foram os fatores discutidos na literatura que poderiam ser atribuídos à determinação dos preços da terra.

Dentre os autores que levantaram principalmente fatores inerentes ao setor agrícola na determinação dos preços da terra, podem-se citar: Chryst (1965), Oliveira e Costa (1977), Reinsel e Reinsel (1979), Doll (1983), Reydon (1989), Bacha (1989) e Rezende (2002).

O crédito rural subsidiado também foi um elemento de suma importância para a formação do preço da terra, pelo menos na década de 70, conforme verificado por vários autores. Enquadram-se nessa corrente: Sayad (1977b), o estudo feito em Agroanalysis (1977), Castro (1981), Rezende (1982), Rezende (1985) e Brandão e Rezende (1989).

O terceiro grupo de autores envolve os que defendem as oscilações econômicas como grandes influentes na determinação do preço da terra. Atribuem grande valor na 
determinação do preço da terra à taxa de juro (Egler, 1985), às fases descendentes do ciclo econômico (Sayad, 1977b, Rangel, 2000, Brandão, 1986) e às fases ascendentes do ciclo econômico e alta liquidez da economia (Pinheiro, 1980, Castro 1981, Pinheiro e Reydon, 1981, Sayad 1982, Brandão e Rezende, 1989, Romeiro e Reydon 1994, Reydon e Plata, 2000 e Dias, Vieira e Amaral, 2001).

A fim de complementar os demais estudos citados neste capítulo, este trabalho pretende examinar econometricamente quais foram os determinantes dos preços de venda e de aluguel da terra (categorias lavoura e pastagem) no estado de São Paulo, de 1969 a 2001.

Posteriormente analisa-se a existência de relação de equilíbrio de longo prazo entre os preços de venda dos diversos tipos de terra dentro de um estado e de diferentes regiões. 


\section{METODOLOGIA}

Ao analisar as diversas referências descritas no capítulo anterior, notou-se que não somente do ponto de vista teórico como também empiricamente há grandes divergências entre os autores sobre os fatores que determinaram o preço da terra no Brasil. Todavia, poucos trabalhos analisaram econometricamente os determinantes dos preços da terra na década de noventa. Dentre os trabalhos que assim o fizeram podem-se citar: Romeiro e Reydon (1994), que usaram séries até o ano de 1991 e Dias, Vieira e Amaral (2001), cuja pesquisa estendeu-se até o ano de 1998. Desta forma, este trabalho analisa os determinantes dos preços da terra nua (lavoura e pastagem) e do arrendamento (para culturas e para gado) no estado de São Paulo, no período de 1969 a 2001, utilizando-se regressão linear múltipla como ferramental econométrico.

Em seguida, testou-se a relação de equilíbrio de longo prazo entre os preços de diferentes tipos de terra dentro do estado de São Paulo e entre os estados do Centro-Sul do país. Para tanto, foi utilizado, primeiramente, o teste de raiz unitária proposto por Fuller (1976) e complementado por Dickey \& Fuller (1979 e 1981) a fim de se determinar a ordem de integração das variáveis. Posteriormente, através da técnica de co-integração segundo a metodologia proposta por Johansen (1988) objetivou-se verificar a existência de relação de equilíbrio de longo prazo entre os preços de terra, dentro do estado de São Paulo e dos preços de terra de lavoura e pecuária deste estado com outros do Centro-Sul. 


\subsection{Procedimentos Econométricos}

Atualmente, tem sido questionada a validade de modelos econométricos que utilizam séries de dados ordenados no tempo. O grande questionamento surge dos pressupostos da econometria clássica, os quais consideram que uma regressão somente será válida se suas séries apresentarem média e variância constantes ao longo do tempo, e covariância, dependendo apenas do intervalo de tempo. Este é o conceito de estacionariedade.

Em suma, uma análise de regressão baseada em dados de séries temporais pressupõe que as séries temporais subjacentes sejam estacionárias, salvo se as séries forem co-integradas, ou seja, se apresentarem relação de equilíbrio estável de longo prazo $^{13}$. Caso as séries regredidas sejam não-estacionárias, a possível relação existente entre elas provavelmente será espúria (duvidosa). Esse problema pode ocorrer se as séries envolvidas na análise apresentarem fortes tendências. Assim, o alto coeficiente de determinação da regressão justificar-se-ia pela existência da tendência, e não pela existência de uma relação verdadeira entre as variáveis.

Se as séries forem não-estacionárias elas são conhecidas como integradas de ordem $d$, em que $d$ é o número de vezes que uma série deve ser diferenciada a fim de se tornar estacionária. Caso seja necessário uma diferença para que a série se torne estacionária, diz-se que ela é integrada de ordem 1, ou I(1). Por conseguinte, na regressão em que as séries de todas as variáveis envolvidas sejam I(1), o modelo deve ser especificado na primeira diferença.

Uma falha surge, entretanto, em decorrência da análise anterior. Ao estimar-se um modelo utilizando as diferenças, perdem-se as relações de longo prazo existentes entre as variáveis. Segundo Gujaratti (2000, p. 731), "a maior parte da teoria econômica é enunciada como uma relação de longo prazo entre as variáveis na forma de nível e não na forma de primeiras diferenças”. Todavia, há uma alternativa para verificar se

\footnotetext{
${ }^{13}$ Vide Gujaratti (2000) para maiores detalhes.
} 
variáveis não estacionárias regredidas em nível produzem relações não-espúrias: se elas forem co-integradas.

Se a combinação linear de duas ou mais variáveis integradas de mesma ordem exibir comportamento de equilíbrio estável de longo prazo, diz-se que a relação entre elas é verdadeira e não espúria, ou seja, tais variáveis são co-integradas. Desta forma, a regressão deve ser estimada em nível e não a partir de suas diferenças, e o resíduo desta regressão deverá ser estacionário.

É importante realçar que uma série de tempo pode representar um processo de tendência determinista ou um processo de tendência estocástica. No primeiro caso, a série é estacionária ao longo de uma tendência determinista, isto é, extraindo-se sua tendência, obtém-se como resultado uma série estacionária. Se para a série tornar-se estacionária for necessário obter sua primeira diferença, diz-se que essa série descreve um processo de diferença estacionária.

Resumindo, para que o resultado de uma regressão, utilizando dados de séries de tempo, seja verdadeiro, é preciso que as séries utilizadas na regressão sejam estacionárias ou, se forem I (d), é preciso que sejam co-integradas (o resíduo desta regressão deve ser estacionário).

Um teste muito utilizado para detectar a ordem de integração de séries temporais é o teste de raiz unitária. Testar o número de raízes unitárias de uma série significa verificar sua ordem de integração.

Contudo, se por um lado existe a discussão sobre a possibilidade de relação espúria entre as variáveis de uma regressão, por outro, há o argumento do baixo poder dos testes de raiz unitária, principalmente em séries com poucas observações. Se o teste de raiz unitária não for confiável, o teste de co-integração também não o será, uma vez que este depende dos resultados daquele.

Segundo Enders (1995), os testes de raiz unitária têm baixo poder (pequena probabilidade de rejeitarem uma hipótese nula falsa) para distinguir o processo de raiz 
unitária de um processo de "quase" raiz unitária. Adiciona que, freqüentemente, estes testes indicarão a presença de raiz unitária e que amostras pequenas podem facilmente apresentar problemas. Segundo este autor, em amostras finitas, qualquer processo de tendência estacionária pode arbitrariamente ser aproximado a um processo de raiz unitária e vice-versa.

A despeito das referidas restrições, no presente estudo testou-se a ordem de integração de todas as variáveis envolvidas na análise dos determinantes dos preços de venda e de arrendamento da terra de cultura e de pastagem. Entretanto, ao alterar o número de defasagens utilizadas para eliminar o problema de auto-correlação dos resíduos, a maioria das séries apresentou problemas. Em muitos casos, uma série poderia ser considerada tanto estacionária quanto integrada de ordem 1 , somente variando o número de defasagens.

Em virtude do argumento explicitado por Enders (1995) para pequenas amostras e das restrições mencionadas anteriormente, para analisar os determinantes dos preços de venda da terra e de arrendamento no estado de São Paulo, optou-se pela regressão linear múltipla como ferramenta econométrica ${ }^{14}$, tendo sido descartados os testes de raiz unitária e co-integração.

Ressalta-se, todavia, que foram utilizados os testes de raiz unitária e cointegração para verificar se há relação entre os preços de diferentes categorias de terra no estado de São Paulo, entre os preços de terra de cultura de primeira e pecuária em São Paulo e os preços de lavoura e pecuária nos estados de Goiás, Mato Grosso, Rio de Janeiro, Espírito Santo, Minas Gerais, Paraná, Santa Catarina e Rio Grande do Sul ${ }^{15}$.

A seguir estão explicitados os pressupostos do modelo de regressão linear múltipla e as consequiências da violação desses pressupostos. Posteriormente detalha-se

\footnotetext{
${ }^{14}$ O programa computacional utilizado para o cálculo das regressões foi o E views 3.0.

${ }^{15}$ Utilizou-se o programa RATS 3.2 para a execução dos testes de raiz unitária e o RATS 3.1 para testar co-integração.
} 
o procedimento do teste de raiz unitária. Em seguida, apresenta-se o procedimento de co-integração, segundo a metodologia proposta por Johansen (1988).

\subsubsection{Regressão Linear Múltipla}

Em cada um dos modelos econométricos estimados, atenta-se para os seguintes pressupostos da regressão linear clássica, os quais podem ser consultados com maior detalhamento em Gujaratti (2000): ausência de auto-correlação dos resíduos e homocedasticia (ambos problemas relacionados ao termo aleatório) e ausência de colinearidade exata entre as variáveis explicativas.

Segundo Diaz (2000), termos de erro não correlacionados no tempo indicam que os resíduos de um período não são correlacionados aos resíduos do período anterior. A presença de auto-correlação nos resíduos gera: a) estimadores dos parâmetros $\left(\beta_{i}\right)$ não viesados, porém não eficientes; b) as variâncias estimadas dos parâmetros são subestimadas, gerando problemas com os testes de hipóteses (Diaz, 2000).

O procedimento utilizado para detectar a presença de autocorrelação de primeira ordem nos modelos estimados foi o teste de Durbin-Watson. Tal teste estabelece a hipótese nula de ausência de autocorrelação. Durbin e Watson derivaram um limite inferior $d_{l}$ e um limite superior $d_{s}$, de tal sorte que se o $d$ calculado estivesse fora do intervalo delimitado por esses valores críticos, poderiam tomar uma decisão quanto à presença de autocorrelação positiva ou negativa (ou não rejeitar a hipótese de ausência de autocorrelação). Na Tabela 1 do apêndice estão as regras a serem seguidas.

Uma maneira de reduzir a autocorrelação é utilizar a variável dependente defasada como uma das variáveis explicativas. Neste caso, o teste de Durbin-Watson não se aplica. Nesta situação, utiliza-se o teste de Durbin h que para amostras grandes, segue a distribuição normal padronizada.

Uma outra importante pressuposição do modelo clássico de regressão linear é

que os termos de erro sejam homocedásticos, ou seja, tenham variância constante. A ausência de homocedasticia, ou seja, heterocedasticia, gera estimadores dos parâmetros 
$\beta$ não viesados mas ineficientes. As variâncias estimadas dos parâmetros são viesadas, gerando problemas com o teste de hipótese (Diaz, 2000).

Para testar a existência de heterocedasticidade (termos de erro com variância não constante), utilizou-se o Teste Geral de Heterocedasticidade de White. Este teste está baseado em: regressão do resíduo ao quadrado contra as variáveis explicativas; variáveis explicativas ao quadrado; produtos dois a dois destas mesmas variáveis explicativas (o resíduo e as variáveis explicativas são os mesmos da regressão da qual se deseja testar a presença de heterocedasticidade). A hipótese nula é de que não há heterocedasticia, ou de que todos os parâmetros desta regressão são iguais a 0 . O teste segue a distribuição de qui-quadrado, com grau de liberdade igual ao número de variáveis explicativas da regressão descrita acima.

Uma última hipótese do modelo clássico de regressão linear a ser analisada neste trabalho é a ausência de relação linear perfeita entre as variáveis explicativas ou, ausência de multicolinearidade.

Segundo Diaz (2000), as principais conseqüências da presença de relação linear entre as variáveis explicativas podem resumir-se em: matriz de variância e covariância com valores muito elevados; possibilidade de conflito entre os resultados dos testes $\mathrm{t}$ e F e do coeficiente de determinação $\left(\mathrm{R}^{2}\right)$; grande sensibilidade dos parâmetros a pequenas mudanças na amostra.

Para verificar a presença de multicolinearidade utilizou-se a matriz de correlações simples. Esta matriz mostra as correlações existentes entre as variáveis explicativas, duas a duas. Em geral, se o coeficiente de correlação entre duas variáveis explicativas for maior que 0,8 , então a multicolinearidade se constitui em um sério problema, conforme pode ser visto em Gujaratti (2000). Contudo, este critério pode levar a conclusões falsas. Embora altas correlações entre as variáveis explicativas sejam indícios de multicolinearidade, não é necessário que elas sejam altas para haver colinearidade. Ainda segundo Gujaratti (2000), em modelos com mais de duas variáveis explicativas, a correlação simples não caracteriza um indício infalível da presença de 
multicolinearidade, uma vez que pode haver relação linear exata entre uma variável explicativa e as demais.

\subsubsection{Teste de raiz unitária}

Fuller (1976) desenvolveu o primeiro teste de raiz unitária considerando um processo auto-regressivo de primeira ordem [AR(1)], conforme mostra a equação (9).

$$
x_{t}=\rho x_{t-1}+\varepsilon_{t}
$$

sendo $\varepsilon_{t}$ ruído branco. Para verificar a existência de raiz unitária, Fuller (1976) testou em (9) a hipótese de que $x_{t}$ é não estacionário, ou seja $H_{0}: \rho=1$ contra $H_{A}: \rho<|1|$, o que equivale a testar em:

$$
\Delta x_{t}=(\rho-1) x_{t-1}+\varepsilon_{t}
$$

a hipótese $\mathrm{H}_{0}: \rho-1=0$ contra $\mathrm{H}_{\mathrm{A}}: \rho-1<0$

A não rejeição da hipótese nula indica que a série não é estacionária, ou seja, a série tem pelo menos uma raiz unitária.

Embora o processo de estimação dos valores a serem testados seja realizado pelo método dos Mínimos Quadrados Ordinários, os valores críticos não seguem a distribuição padrão $t$ de Student, mas os valores das distribuições denominadas ô.

Dickey e Fuller (1979) consideraram três diferentes equações de regressão, nas quais pode-se testar a presença de raiz unitária. A primeira é a equação (10) e as demais serão exibidas a seguir:

$$
\begin{gathered}
\Delta x_{t}=\alpha+(\rho-1) x_{t-1}+\varepsilon_{t} \\
\Delta x_{t}=\alpha+\beta t+(\rho-1) x_{t-1}+\varepsilon_{t}
\end{gathered}
$$


Nota-se que a equação (12) possui um componente auto-regressivo, um intercepto e uma tendência; a equação (11) apresenta somente o componente autoregressivo e intercepto, enquanto a equação (10) é um passeio aleatório.

Para testar a presença de raiz unitária nas equações (10), (11) e (12) são utilizadas as estatísticas $\hat{o}, \hat{o}_{i}$ e $\hat{o}_{\hat{o}}$, respectivamente.

$\mathrm{Na}$ equação (12) que inclui o intercepto e a tendência utiliza-se a estatística $\hat{o}_{\hat{o}}$ para testar o coeficiente do componente auto-regressivo; a estatística $\hat{o}_{\hat{a} \hat{o}}$ para o coeficiente da tendência, e a estatística $\hat{o}_{i o ̂}$ para testar se o intercepto é igual a zero. Se a hipótese de que â $=0$ for rejeitada, utiliza -se a distribuição normal par testar se $\tilde{n}=1$. Pode-se utilizar a estatística $\ddot{O}_{3}$ para testar a hipótese conjunta de $a ́=0, \hat{a}=0$ e $\tilde{n}=1$, de acordo com Dickey e Fuller (1981).

Ao incluir o intercepto mas não a tendência, são utilizados os valores críticos da

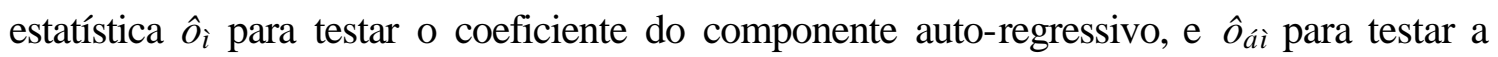
presença do intercepto. Se o intercepto não for igual a zero, dado que o coeficiente autoregressivo é zero (pela estatística $\hat{o}_{i}$ ), utiliza-se a distribuição normal para testar se $\tilde{n}=1$. Pode-se utilizar a estatística $\ddot{O}_{1}$ para testar a hipótese conjunta de $a ́=0$ e $\tilde{n}=1$, de acordo com Dickey e Fuller (1981).

Finalmente, para a regressão sem termos deterministas, ou seja, sem intercepto e sem tendência são utilizados os valores críticos da estatística ô, pois testa-se somente o coeficiente do componente auto-regressivo. Se a hipótese de não estacionariedade for rejeitada, conclui-se que a série é $\mathrm{I}(0)$; caso contrário, estima-se este modelo novamente, porém, com uma diferença a mais. Repete-se este processo até que se rejeite a hipótese de raiz unitária. O número de diferenças necessárias para que se rejeite a hipótese de raiz unitária será igual à ordem de integração da série.

Se a série for descrita por um processo auto-regressivo de ordem $p$, testa-se o seguinte modelo: 


$$
\Delta x_{t}=\alpha+\beta t+\gamma x_{t-1}+\sum_{i=1}^{p-1} \lambda_{t} \Delta x_{t-i}+\varepsilon_{t}
$$

em que: $\lambda_{i}=-\sum_{j=i+1}^{p} \rho_{j}$ e $\gamma=\sum_{i=1}^{p} \rho_{i}-1$. O teste de raiz unitária, nesse caso, passa a ser chamado de teste de Dickey-Fuller Aumentado (ADF). A hipótese a ser testada para detectar a presença de raiz unitária passa a ser: $\mathrm{H}_{0}: \gamma=0$.

Para determinar a ordem do processo auto-regressivo gerador da série, foram adotados os critérios de Akaike (AIC) e Schwartz (SC), por serem os mais aplicados em trabalhos empíricos. $\mathrm{O}$ procedimento consiste em estimar várias regressões representativas de modelos auto-regressivos, de diferentes ordens. Aquela que exibir o menor valor para os critérios de AIC e SC representa o modelo mais adequado. ${ }^{16}$

As equações de AIC e SC são exibidas a seguir:

$$
\begin{aligned}
& A I C=\ln \hat{\sigma}^{2}+\frac{2}{N}(\text { número de parâmetros }) \\
& S C=\ln \hat{\sigma}^{2}+\frac{\ln N}{N} \text { (número de parâmetros) }
\end{aligned}
$$

em que $\hat{\sigma}^{2}$ é a soma dos quadrados dos resíduos estimados do processo auto-regressivo de ordem $p$, e $N$ corresponde ao número de observações da amostra.

Como procedimento auxiliar da determinação da ordem $p$ do modelo a ser testado, utilizou-se o teste $Q$ de Ljung-Box. Esse teste indica se há correlação serial no modelo. Enfim, procurou-se adotar modelos que conciliassem resíduos não correlacionados e o princípio da parcimônia (menor número de defasagens possível).

\footnotetext{
16 Deve-se atentar para o fato de que os critérios de AIC e SC indicam a ordem $p$ do processo autoregressivo para a regressão em nível. Se o teste de raiz unitária for feito em modelos nas diferenças, como na equação (13), a ordem a ser adotada deverá ser $p \quad 1$.
} 
Os testes de raiz unitária realizados neste trabalho seguiram os procedimentos descritos anteriormente. Primeiramente determinou-se a ordem $p$ do modelo a ser estimado, pelos critérios de AIC, SC e teste $Q$ de Ljung-Box. Em seguida, aplicou-se o teste de Dickey-Fuller Aumentado (ADF), partindo-se do modelo mais geral (com componente auto-regressivo, tendência e intercepto) até chegar ao modelo mais simples (somente com componente auto-regressivo), se a hipótese de raiz unitária não tiver sido rejeitada anteriormente ${ }^{17}$.

\subsubsection{Teste de co-integração: o método de Johansen}

Testar co-integração significa verificar se existe ao menos uma relação estacionária entre as variáveis envolvidas na análise, dado que essas variáveis são integradas de mesma ordem. No caso de duas variáveis, existirá, no máximo, uma relação estacionária entre elas e o teste a ser aplicado é o de Engle e Granger (1987). Se a análise envolver mais de duas variáveis, deve-se adotar o procedimento de Johansen (1988), que permite testar a presença de múltiplos vetores de co-integração.

De maneira intuitiva, o procedimento de Johansen é uma generalização multivariada do teste de Dickey-Fuller. Considerando um modelo auto-regressivo de ordem $1, \operatorname{com} n$ variáveis, tem-se:

$$
x_{t}=\mathrm{A}_{1} x_{t-1}+\varepsilon_{t}
$$

tal que:

$$
\begin{gathered}
\Delta x_{t}=\mathrm{A}_{1} x_{t-1}-x_{t-1}+\varepsilon_{t} \\
\Delta x_{t}=\left(\mathrm{A}_{1}-I\right) x_{t-1}+\varepsilon_{t} \\
\Delta x_{t}=\pi x_{t-1}+\varepsilon_{t}
\end{gathered}
$$

\footnotetext{
${ }^{17}$ Para detalhes dos passos seguidos para execução do teste de Dickey e Fuller Aumentado veja Enders (p.
} 257, 1995). 
sendo:

$$
\begin{aligned}
& x_{t} \text { e } \varepsilon_{t}=\text { vetores }(n \times 1) \\
& \mathrm{A}_{1}=\text { matriz de parâmetros }(n \times n) \\
& I=\text { matriz identidade }(n \times n) \\
& \pi=\left(\mathrm{A}_{1}-I\right)
\end{aligned}
$$

$\mathrm{O}$ posto de $\left(\mathrm{A}_{1}-I\right)$ é igual ao número de vetores de co-integração. Se $\pi$ tiver posto igual zero, não haverá nenhuma combinação linear dos $x_{i t}$ que seja estacionária, e as variáveis não serão co-integradas. Se o posto da matriz $\pi$ for igual a $n$, todas as variáveis em análise são estacionárias. Se, entretanto, o posto da matriz $\pi$ estiver entre 0 e $n$, as variáveis são co-integradas.

A equação (19) pode ser modificada de diversas maneiras. Pode-se incluir, por exemplo, um intercepto, se as séries assim permitirem. Neste estudo, incluiu-se um termo denominado constante restrita. Trata-se da inclusão de uma constante nas relações de co-integrações, o que aumenta $x_{t-1}$ em um valor constante.

Assim como o teste de Dickey-Fuller Aumentado, o teste de co-integração para o caso multivariado também pode ser generalizado a processos auto-regressivos de ordens maiores que 1. A representação do modelo auto-regressivo de ordem $p$ seria:

$$
\Delta x_{t}=\sum_{i=1}^{p-1} \pi_{i} \Delta x_{t-i}+\pi x_{t-p}+\varepsilon_{t}
$$

em que: $\pi=-\left(I-\sum_{i=1}^{p} \mathrm{~A}_{i}\right)$ e $\pi_{i}=-\left(I-\sum_{j=1}^{i} \mathrm{~A}_{j}\right)$

Os critérios de Akaike (AIC) e Schwartz (SC), em um contexto multiequacional, são utilizados para a determinação do valor de $p$. 
Os testes utilizados para verificar o número de vetores de co-integração em um modelo denominam-se $\lambda_{\text {traço }}$ e $\lambda_{\text {max }}$ e são descritos a seguir:

$$
\begin{aligned}
& \lambda_{\text {traço }}=-\mathrm{T} \sum_{i=r+1}^{n} \ln \left(1-\hat{\lambda}_{i}\right) \\
& \lambda_{\max }=-\mathrm{T} \ln \left(1-\hat{\lambda}_{r+1}\right)
\end{aligned}
$$

em que:

$\hat{\lambda}_{i}=$ valores estimados das raízes características obtidas da matriz $\pi$ estimada.

$\mathrm{T}=$ número de observações utilizadas.

Os valores críticos desses testes encontram-se em Johansen \& Juselius (1990).

\subsection{Os modelos econométricos}

A fim de estimar regressões para os preços de terra de cultura de primeira, preço de pastagem, valor de arrendamento e aluguel de pasto, discorre-se, no subitem 3.2.1, o procedimento de seleção das variáveis explicativas. Em 3.2.1.1 faz-se a descrição de todas as variáveis utilizadas na pesquisa e suas fontes de dados. O subitem 3.2.1.2 aborda as hipóteses a serem testadas acerca das variáveis explicativas utilizadas nas regressões e também as expectativas quanto aos resultados dos testes de cointegração. Nesse mesmo subitem mostra-se, graficamente, a evolução de cada uma das séries utilizadas na pesquisa.

\subsubsection{Seleção das variáveis utilizadas}

A seguir, descreve-se o procedimento de seleção das variáveis utilizadas nas regressões lineares e nos testes de co-integração.

Tendo sido analisadas as diversas referências sobre os determinantes dos

preços da terra, foram selecionadas variáveis de interesse micro e macroeconômico para 
compor os modelos de determinação dos preços de terra de cultura de primeira, terra de pastagem, arrendamento para culturas e aluguel de pasto para animais.

As variáveis selecionadas para analisar o lado produtivo da terra, ou seja, os determinantes do preço da terra relacionados ao próprio setor agrícola foram: poder de compra do agricultor (que engloba a evolução da produtividade das principais culturas do estado), preços recebidos pelo agricultor, preços pagos pelo agricultor, índice de paridade (termos de troca) e volume de subsídio ao crédito rural.

A fim de representar o ambiente macroeconômico, estimou-se a taxa de inflação anual vigente no período, uma proxy para o hiato do produto, a taxa de juro real, a extensão da rede rodoviária total do estado de São Paulo proxy de medida da infraestrutura disponível) e uma variável binária, para verificar se houve alteração significativa do nível de preços de terra, no período 1973 - 94, uma vez que empiricamente observou-se tal alteração.

Para testar co-integração, foram selecionados, primeiramente, os preços de terra das cinco categorias existentes, classificadas pelo IEA para o estado de São Paulo: terra de cultura de primeira, terra de cultura de segunda, terra para pastagem, terra para reflorestamento e terra para campo.

Posteriormente, testou-se a co-integração entre os preços de terra de cultura de primeira e de pastagem, no estado de São Paulo e os preços de lavoura e pastagem nos estados do Centro-Sul, exceto Tocantins e Mato Grosso do Sul. Estes são estados formados mais recentemente, cujos preços de venda de terra passaram a ser coletados em 1990 e 1977, respectivamente. A escolha do Centro-Sul deveu-se em virtude da melhor qualidade dos dados referentes aos estados destas regiões. 


\subsubsection{Descrição das variáveis e fontes de dados}

As fontes de dados das variáveis escolhidas para a pesquisa provêm de instituições diversas. Cabe ressaltar que o período de abrangência de todas as séries é de 1969 a 2001, exceto a série de taxa de juro real, que vai de 1974 a 2001. Todas as séries foram deflacionadas pelo IGP-DI (obtido da base de dados do Instituto de Pesquisa Econômica Aplicada - IPEA), índice $1994=100$ e trazidas para reais do mês de dezembro de 2001.

A seguir, descreve-se cada uma das variáveis utilizadas, os procedimentos de estimação e suas respectivas fontes.

\subsection{Variáveis utilizadas nas regressões}

a) PTCULT $=$ preço médio de venda da terra de cultura de primeira (terra nua) no estado de São Paulo, em reais por hectare. Esses preços são publicados pelo Instituto de Economia Agrícola -IEA e divulgados em unidades monetárias originais.

Segundo definição do IEA (1993, p. 11), “devem ser consideradas terras de cultura de primeira aquelas potencialmente aptas para culturas anuais, perenes e outros usos, que suportam um manejo intensivo de práticas culturais, preparo de solo, etc. São terras de produtividade média e alta, mecanizáveis, planas ou ligeiramente declivosas e os solos são profundos e bem drenados."

Os preços médios de venda da terra de cultura de primeira, no estado de São Paulo, foram coletados em diferentes meses no decorrer do período em análise. De 1969 a 1975, tais preços foram coletados em janeiro. A partir de 1976, passaram a ser coletados em fevereiro e não mais em janeiro. Em 1979 a coleta de dados tornou-se bianual, continuando no mês de fevereiro e incorporando os dados do mês de novembro. Em 1980, os dados de junho foram substituídos pelos dados de novembro. A partir de 1981, a coleta de dados passou a ser realizada três vezes ao ano: em fevereiro, junho e novembro e continuou desta maneira até 1998. Em 1999 foram coletados dados somente em junho e novembro, permanecendo desta forma até o final do período da pesquisa. 
Os preços utilizados nas estimativas foram obtidos efetuando-se a média aritmética anual dos preços em reais, já deflacionados.

b) PTPAST = preço médio de venda da terra de pastagem (terra nua) no estado de São Paulo, em reais por hectare.

Segundo definição do IEA (1993, p.11), "nessa categoria devem ser consideradas as terras impróprias para culturas, mas potencialmente aptas para pastagem e silvicultura. São terras de baixa fertilidade, planas ou acidentadas, com exigência quanto às práticas de conservação e manejo de simples a moderadas, considerando o uso indicado".

Os preços de terra de pastagem utilizados nesta pesquisa também foram obtidos do IEA e elaborados da mesma maneira que os preços de terra de cultura de primeira.

c) ARCULT = valor médio de arrendamento para terra de lavoura, em reais/ha/ano.

Os dados referentes ao arrendamento são coletados anualmente no mês de novembro e divulgados pelo IEA, em moeda corrente. Excepcionalmente, nos anos de 1969, 1970, 1972 e 1997-99, o Instituto não divulgou estes preços. Os dados de valor de arrendamento para os anos de 1969 e 1970 e 1972 são provenientes de Ferreira e Camargo (1987). Já para os anos de 1997-99, os dados foram cedidos pelo próprio IEA. No decorrer do período em análise, a coleta destes dados sofreu algumas mudanças, que são mencionadas a seguir.

O valor do arrendamento passou a ser coletado pelo IEA a partir de $1971 \mathrm{e}$ incluía as seguintes culturas: algodão, amendoim, arroz, milho e cana, sendo que esta última foi incluída somente a partir de 1988. Em 1991, foram incluídas as culturas de soja e tomate envarado; o valor de arrendamento passou a ser coletado individualmente para algodão, amendoim, arroz, milho, cana, soja e tomate envarado. 
Nesta pesquisa foram utilizados os dados de valor de arrendamento discutidos anteriormente, atualizados para dezembro de 2001. Após 1991 a série divulgada passou a ser específica para cada cultura, então efetuou-se a média aritmética dos valores de arrendamento das culturas especificadas. A série de tomate envarado foi excluída da pesquisa, uma vez que apresentou alguns valores aparentemente viesados. Desta forma, a partir de 1991, a série de valor de arrendamento foi construída com os valores de arrendamento das culturas de algodão, amendoim, arroz, milho, cana e soja.

d) ARPAST $=$ aluguel de pasto em reais/cabeça/ano.

Esta série é coletada no mês de junho e divulgada anualmente pelo IEA, em moeda corrente/cab/mês, desde 1972. A partir de 1980, passou a ser coletada também em novembro. Entretanto, nesta pesquisa foram utilizados somente os dados de junho, transformados para reais/cabeça/ano. Os dados referentes aos anos de 1969-1971têm como fonte Ferreira e Camargo (1987).

e) VCRSUB $=$ Volume de subsídio concedido aos produtores e às cooperativas do estado de São Paulo, pelo Sistema Nacional de Crédito Rural.

O valor do subsídio concedido através do crédito foi calculado com base na metodologia proposta por Shirota (1988). Os valores para tal variável foram obtidos multiplicando-se o volume de crédito rural, concedido aos produtores e às cooperativas do estado de São Paulo, pela taxa de juros real do crédito, concedido aos produtores e às cooperativas do Centro-Sul do país.

Esta metodologia decompõe o volume de crédito concedido em custeio, investimento e comercialização, considerando os prazos médios de financiamento como 9, 12 e 3 meses, respectivamente. Porém, neste trabalho, não foram utilizadas estas ponderações.

Posteriormente, calcula-se a média dos juros nominais prevalecentes para cada tipo de contrato e determina-se a taxa de juros em relação à taxa anual de inflação: 


$$
r=\frac{(j-i)}{(1+i)}
$$

em que:

$r=$ taxa de juros real do crédito rural;

$j=$ taxa nominal de juros no crédito rural;

$i=$ taxa de inflação.

É interessante notar que, nesta metodologia, o subsídio é calculado apenas como o diferencial entre a taxa de juros dos empréstimos e a taxa de inflação da economia, e não como o diferencial em relação à taxa de juros média da economia.

Os dados da taxa de juros real do crédito rural foram extraídos de Shirota (1988) para o ano de 1969 e de Franca (1996) para o período de 1970 a 1995. De 1996 a 2001, utilizou-se a taxa de juros efetiva de $8,75 \%$ ao ano (tendo sido considerada como taxa de juros nominal de crédito rural), divulgada pelo Banco Central. A taxa de inflação utilizada no cálculo da taxa de juros real no período de 1996 a 2001 foi obtida pela variação do IGP-DI de dezembro a dezembro, de cada ano considerado.

Os dados sobre o montante de crédito rural concedido aos produtores e às cooperativas do estado de São Paulo foram extraídos do Anuário Estatístico do Crédito Rural - Bacen.

Os valores de subsídio concedidos foram obtidos através do produto da taxa de juros real do crédito rural pelo montante de crédito rural deflacionado pelo IGP-DI, base dezembro de 2001.

f) $\quad$ IPR = índice de preços recebidos pelos produtores, com base dezembro de $2001=100$. 
O índice de preços recebidos pelos produtores é um indicativo da evolução mensal dos preços médios de 19 produtos agrícolas (incluindo produtos animais). É um índice de Laspeyres divulgado pelo IEA, cuja estrutura de ponderação, até julho de 1989, compreendia as quantidades médias produzidas no período 1962-66.

A partir de agosto de 1989, o índice mensal de preços recebidos pelos produtores passou a ser construído através do método de Laspeyres de base móvel. Esse procedimento teve o intuito de sanar as distorções ocorridas considerando-se invariáveis os pesos na ponderação dos preços dos diversos produtos. Passaram a ser utilizados preços médios mensais de 21 produtos agrícolas, responsáveis por $96,48 \%$ do valor total da produção agrícola do Estado de São Paulo, no período de 1986 a 1988. Os pesos utilizados para a ponderação dos preços foram as participações de cada produto no valor médio da produção, nesses três anos considerados. Anualmente essas participações foram alteradas, usando-se uma média móvel trienal.

Neste trabalho efetuou-se a média destes índices a fim de se obterem valores anuais.

g) IPP = índice de preços pagos pelos produtores, com base de comparação dezembro de 2001=100.

Assim como o IPR, o IPP também é divulgado pelo IEA. Este índice mensal utilizou, até julho de 1989, o sistema de Laspeyres de base fixa, no qual a estrutura de dispêndio dos agricultores paulistas de 1958/59 era a base fixa de ponderação. Em função das mudanças na estrutura produtiva da agricultura e dos setores a ela ligados, o IPP foi reformulado a partir de agosto de 1989, a fim de captar essas transformações.

A nova metodologia de construção do IPP, implantada a partir de agosto de 1989, utiliza o sistema de ponderação obtido em pesquisa de composição dos gastos da agricultura paulista de 1980/1981. Para o cálculo do IPP foi utilizada a fórmula de Laspeyres de base móvel, sendo a comparação dos preços do mês em questão feita com 
os preços do mês imediatamente anterior, mantendo-se, no entanto, fixa a estrutura de ponderação.

Para chegar ao resultado final utilizado neste trabalho, efetuou-se a média aritmética dos índices mensais, obtendo-se, como resultado, um índice médio anual.

h) IP = índice de paridade ou termos de troca. Obtido pela relação entre IPR e IPP.

i) $\mathrm{PC}=$ poder de compra do agricultor. Esta variável foi obtida multiplicando-se o índice de paridade (termos de troca) por um índice de produtividade de Laspeyres. Esta metodologia foi obtida de Tweeten (1989).

A metodologia para o cálculo do índice de produtividade de Laspeyres pode ser vista em Hoffmann (1998). Trata-se da média ponderada das produtividades das culturas de maior importância no estado de São Paulo, no período de 1969 a $2001^{18}$, tendo como fator de ponderação a participação de cada uma das culturas no valor da produção da agropecuária do estado de São Paulo, no ano de 2001 (ano base).

As produtividades das culturas consideradas foram obtidas através de dados de produção e da área das mesmas culturas, cuja fonte é o IEA. O mesmo se aplica para a participação no valor da produção agropecuária.

Multiplicando-se o índice de paridade (discutido anteriormente), pelo índice de produtividade de Laspeyres, obtém-se a variável poder de compra do agricultor, cuja referência é o ano de 2001.

j) LTINF = logaritmo da taxa de inflação anual. A taxa de inflação anual foi medida pela variação do IGP-DI de dezembro a dezembro de cada ano, sendo 1994 o ano base igual a 100. A fonte de dados é o IPEA. Optou-se pela transformação da

18 As culturas consideradas são: algodão, amendoim, arroz, batata, cana, cebola, feijão, mamona, mandioca, milho, soja, tomate, banana, café e laranja. 
variável taxa de inflação na forma logarítmica pois, desta forma, as regressões estimadas apresentaram melhores resultados.

1) HIATO $=$ proxy do hiato do produto. Define-se hiato do produto como a diferença entre o PIB observado e o PIB de tendência, dividida pelo PIB de tendência. Tal metodologia está de acordo com aquela elaborada por Dias, Vieira e Amaral (2001).

O PIB considerado no estudo corresponde ao Produto Interno Bruto do estado de São Paulo, em mil reais. Para o cálculo desta série multiplicou-se o PIB do Brasil (em valores correntes) pela participação do estado de São Paulo no Produto do país. A fonte dos dados da série do PIB brasileiro é o IPEA. Já, a fonte da participação do estado de São Paulo no PIB varia bastante e será descrita a seguir.

Para 1969, tal observação foi extraída do IEA (1972, p.18). De 1970 a 1979 houve somente duas observações do PIB do estado de São Paulo, às quais correspondem os anos de 1970 e 1975 e divulgadas pelo IPEA/IBGE. Desta forma, para os dados dos anos de 1971-74 e 1976-79, foram feitas estimativas por interpolação linear. De 1980 a 1998 os dados foram obtidos da fundação Seade e no ano de 1999, diretamente das Contas Regionais (IBGE). Para os anos de 2000 e 2001, os dados em questão ainda não foram divulgados. Entretanto, tomou-se a média da participação do estado no PIB nos três últimos anos como estimativas aproximadas para os anos de 2000 e 2001.

Vale ressaltar que o PIB do estado de São Paulo também foi deflacionado pelo IPG-DI e trazido para valores de dezembro de 2001. Após ser indexado em 2001 (2001=100), construiu-se o PIB de tendência, efetuando-se a média móvel de 5 anos.

Finalmente, construiu-se a variável proxy do hiato do produto: PIB observado menos o PIB de tendência, divididos pelo PIB de tendência, conforme descrito anteriormente.

m) $\quad$ TJ = taxa de juro real. Corresponde à taxa de juro nominal Selic (divulgada pelo Banco Central do Brasil), deflacionada pelo IGP-DI base ago $94=100$. 
O período de abrangência desta série é de 1974 (ano em que foi criada a taxa Selic) a 2001.

As séries de taxa de juro nominal e do IGP-DI foram obtidas do banco de dados do IPEA.

n) $\quad$ RODO = extensão da rede rodoviária total (rodovias pavimentadas e não pavimentadas - redes federal, estadual e municipal), em quilômetros.

Os dados são provenientes da base do Grupo de Estudos para Integração da Política de Transportes - GEIPOT. Nos anos de 1976, 1977 e 1978 houve uma mudança na metodologia de coleta destes dados, fato que elevou a extensão da malha rodoviária do estado de São Paulo a um nível superior ao dos anos anteriores e posteriores a este período $^{19}$. Para contornar este problema, construiu-se uma variável binária, a qual assume valor 1 de 1976 a 1978 e 0 nos demais anos.

Os dados referentes aos anos de 1994, 1996 e 1998 foram construídos por interpolação linear, uma vez que a instituição não divulgou tais dados. Optou-se por esta aproximação uma vez que não foram observadas grandes mudanças na série nesta fase.

A extensão da malha rodoviária do estado de São Paulo, para o ano de 2001, não foi divulgada. Desta maneira, optou-se por repetir o mesmo valor divulgado em 2000.

o) $\quad$ BINR = binária que assume valor 1, de 1976 a 1978, e 0 nos demais anos. A construção desta variável teve o intuito de corrigir a distorção da série de dados da extensão da malha rodoviária do estado de São Paulo, em decorrência da mudança na metodologia adotada pelo GEIPOT para cálculo desta variável, nos anos de 1976 a 1978.

p) $\quad$ BIN = variável binária que foi construída com a finalidade de verificar se houve alteração no nível de preços de venda da terra (lavoura e pastagem) e no nível do valor de arrendamento para culturas e aluguel de pasto, no período 1973-94.

${ }^{19}$ Os dados referentes à extensão da malha rodoviária total do estado de São Paulo podem ser vistos no Anexo B. 
Esta variável assume valor 1 de 1973 a 1994. De 1969 a 1972, assume valor zero, assim como de 1995 a 2001. Realça-se que a escolha deste período se deu pela observação dos dados graficamente, ou seja, empiricamente notou-se esta alteração no nível dos dados.

3.2.1.1.2 Variáveis utilizadas nos testes de raiz unitária e co-integração

a) Preço da terra de cultura de primeira $=$ preço da terra de cultura de primeira no estado de São Paulo. É a mesma variável descrita anteriormente.

b) Preço da terra de cultura de segunda = preço médio de venda da terra de cultura de segunda (terra nua) no estado de São Paulo, em reais por hectare.

Segundo definição do IEA (1993, p. 11), “devem ser consideradas terras de cultura de segunda aquelas que, apesar de serem aptas para culturas anuais, perenes e outros usos, apresentam limitações bem mais sérias que a terra de cultura de primeira. Podem apresentar problemas para a mecanização devido a uma declividade mais acentuada, porém os solos são profundos, bem drenados, de boa fertilidade, podendo necessitar, às vezes de algum corretivo. Pelas restrições apresentadas, são terras que não devem ser utilizadas continuamente com culturas anuais. Prestam-se, porém, à exploração de plantas perenes e pastagem que proporcionem proteção ao solo."

c) Preço da terra de pastagem = preço médio de venda da terra de pastagem (terra nua) no estado de São Paulo, em reais por hectare.

Segundo definição do IEA (1993, p. 11), devem ser consideradas terras para pastagem "as terras impróprias para culturas, mas potencialmente aptas para pastagem e silvicultura. São terras de baixa fertilidade, planas ou acidentadas com exigências quanto às práticas de conservação e manejo de simples a moderadas, considerando o uso indicado."

d) Preço da terra de reflorestamento = preço médio de venda das terras próprias ao reflorestamento no estado de São Paulo, em reais por hectare. 
Segundo definição do $\operatorname{IEA~(1993,~p.~11),~as~terras~para~reflorestamento~são~}$ aquelas consideradas "impróprias para culturas perenes e pastagens, mas potencialmente aptas para a silvicultura e vida silvestre, cuja topografia pode variar de plana a bastante acidentada e podem apresentar fertilidade muito baixa."

e) Preço da terra de campo = preço médio de venda de terras consideradas campos, em reais por hectare.

Segundo definição do IEA (1993, p. 11), campos "são terras com vegetação natural, primária, ou não, com possibilidades restritas de uso para pastagem ou silvicultura, cujo melhor uso é o do abrigo da flora e da fauna."

As séries das cinco categorias de terras descritas anteriormente são divulgadas em unidades monetárias originais pelo IEA.

Os preços médios de venda de terra de cultura de primeira, de segunda, pastagem, reflorestamento e campos, no estado de São Paulo, foram coletados em diferentes meses no decorrer do período em análise. De 1969 a 1975, tais preços foram coletados em janeiro. A partir de 1976, passaram a ser coletados em fevereiro e não mais em janeiro. Em 1979 a coleta de dados tornou-se bianual, continuando no mês de fevereiro e incorporando os dados do mês de novembro. Em 1980, os dados de junho foram substituídos pelos dados de novembro. A partir de 1981, a coleta de dados passou a ser realizada três vezes ao ano: em fevereiro, junho e novembro e continuou desta maneira até 1998. Em 1999 foram coletados dados somente em junho e novembro, permanecendo desta forma até o final do período da pesquisa.

Os preços utilizados nas estimativas foram obtidos efetuando-se a média aritmética anual dos preços em reais já deflacionados.

f) LGO = preço médio da venda de terra de lavoura no estado de Goiás, em reais por hectare. 
g) $\quad$ PGO = preço médio da venda de terra de pecuária no estado de Goiás, em reais por hectare.

h) LMT = preço médio da venda de terra de lavoura no estado de Mato Grosso, em reais por hectare.

i) PMT = preço médio da venda de terra de pecuária no estado de Mato Grosso, em reais por hectare.

j) LRJ = preço médio da venda de terra de lavoura no estado do Rio de Janeiro, em reais por hectare.

k) $\mathrm{PRJ}=$ preço médio da venda de terra de pecuária no estado do Rio de Janeiro, em reais por hectare.

1) LES = preço médio da venda de terra de lavoura no estado do Espírito Santo, em reais por hectare.

m) $\mathrm{PES}=$ preço médio da venda de terra de pecuária no estado do Espírito Santo, em reais por hectare.

n) $\mathrm{LMG}=$ preço médio da venda de terra de lavoura no estado de Minas Gerais, em reais por hectare.

o) PMG = preço médio da venda de terra de pecuária no estado de Minas Gerais, em reais por hectare.

p) LPR = preço médio da venda de terra de lavoura no estado do Paraná, em reais por hectare.

q) $\quad$ PPR = preço médio da venda de terra de pecuária no estado do Paraná, em reais por hectare.

r) $\mathrm{LSC}=$ preço médio da venda de terra de lavoura no estado de Santa Catarina, em reais por hectare. 
s) $\quad$ PSC = preço médio da venda de terra de pecuária no estado de Santa Catarina, em reais por hectare.

t) $\quad$ LRS = preço médio da venda de terra de lavoura no estado do Rio Grande do Sul, em reais por hectare.

u) $\quad \mathrm{PRS}=$ preço médio da venda de terra de pecuária no estado do Rio Grande do Sul, em reais por hectare.

Os preços da terra de lavoura e pastagem dos estados de Goiás, Mato Grosso, Rio de Janeiro, Espírito Santo, Minas Gerais, Paraná, Santa Catarina e Rio Grande do Sul são divulgados semestralmente pela Fundação Getúlio Vargas - FGV. Tais preços são coletados em junho e novembro de cada ano e divulgados em Reais correntes por hectare.

Os preços utilizados nas estimativas foram obtidos efetuando-se a média aritmética anual dos preços em reais já deflacionados.

\subsubsection{Hipóteses subjacentes às variáveis selecionadas}

Descreve-se, primeiramente, neste item, as expectativas quanto ao comportamento das variáveis selecionadas com respeito a cada uma das regressões a serem estimadas. A fim de apresentar as séries a serem utilizadas e justificar as hipóteses formuladas, mostra-se graficamente o comportamento de cada uma das variáveis descritas.

Em seguida, expõem-se as expectativas quanto à relação existente entre os preços de terra de diferentes categorias, dentro do estado de São Paulo. Discutem-se também as hipóteses referentes ao comportamento dos preços de terra de lavoura e pastagem entre o estado de São Paulo e os estados do Centro-Sul. Apresenta-se, ainda, o comportamento dessas séries graficamente.

As primeiras variáveis mostradas graficamente (vide Figura 2) correspondem aos preços de venda da terra de cultura de primeira e terra de pastagem. 
A seguir, apresenta-se na Figura 3 a evolução do valor do arrendamento para culturas e do aluguel de pasto. Tanto estas quanto as primeiras variáveis apresentadas são explicadas econometricamente.

É possível notar que os movimentos de preços de terra de cultura de primeira e terra de pastagem são semelhantes. O mesmo não pode ser dito para arrendamento e aluguel de pasto.

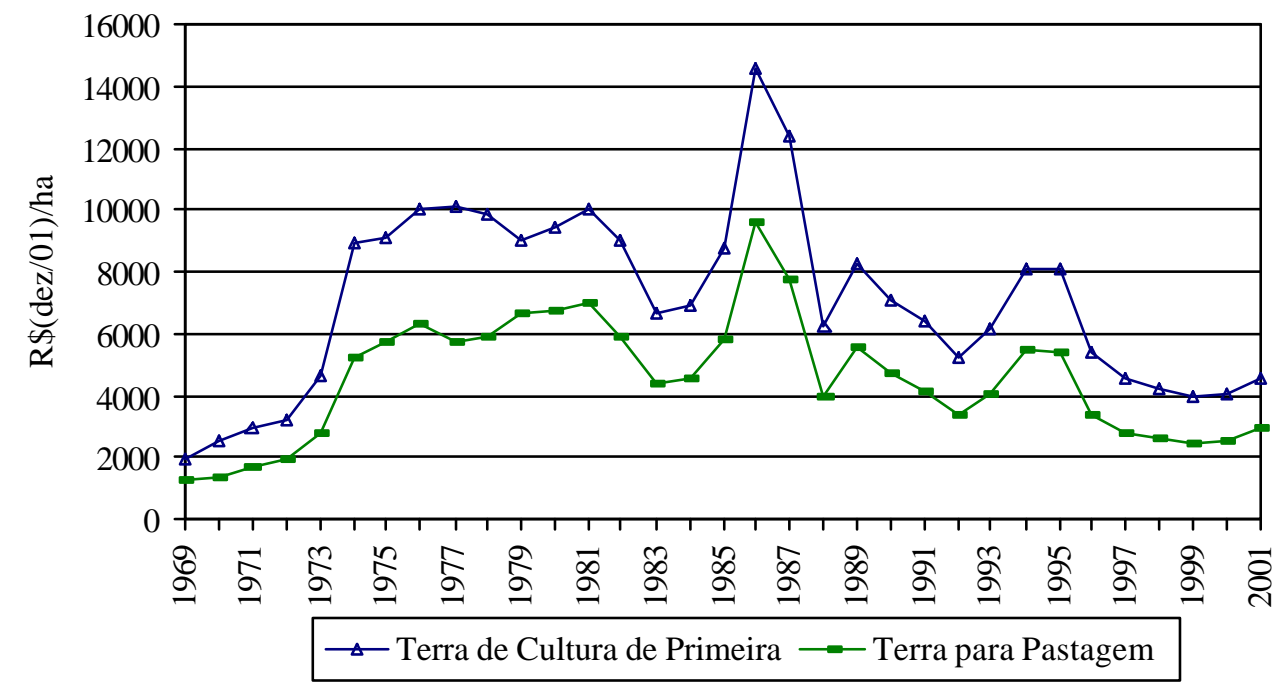

Figura 2 - Evolução dos preços da venda de terra de cultura de primeira e de pastagem, no estado de São Paulo, de 1969 a 2001.

Fonte: IEA 


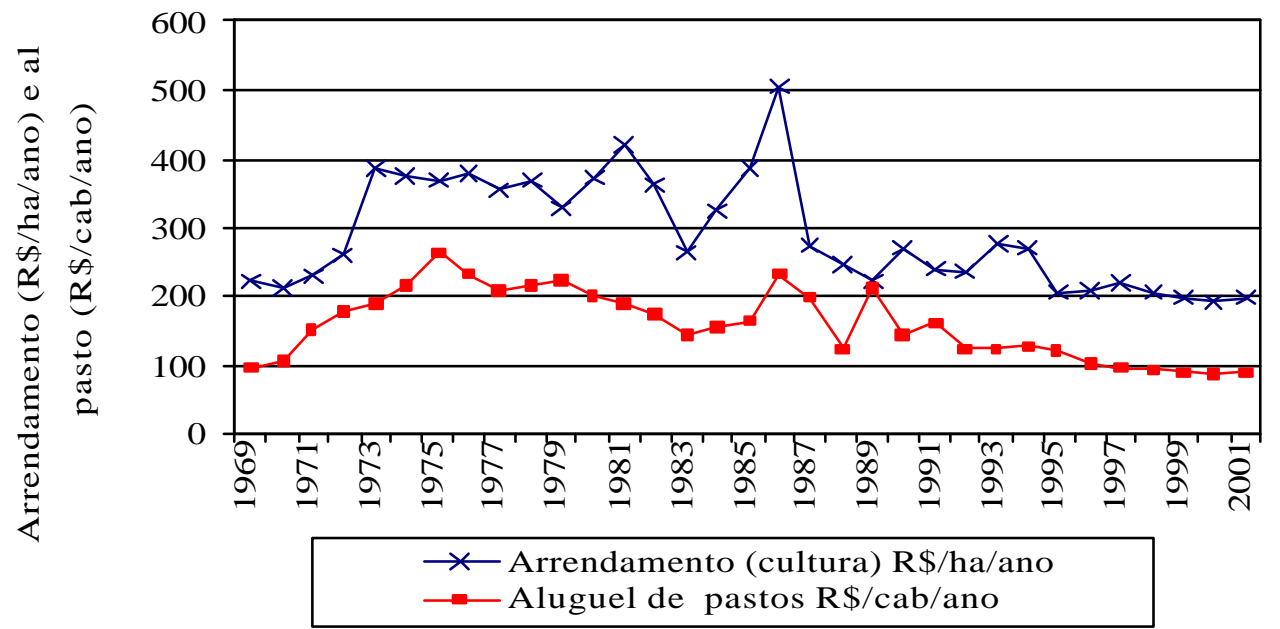

Figura 3 - Evolução do valor do arrendamento para culturas e do aluguel de pasto, no estado de São Paulo, de 1969 a 2001.

Fonte: IEA

Com relação ao volume de subsídio creditício concedido, espera-se que esta variável mantenha uma relação direta com os preços de venda das terras de cultura de primeira e de pastagem. Quanto à sua influência no valor do arrendamento e no aluguel de pasto, há controvérsias na literatura. A grande questão é se o crédito rural influenciou o mercado de arrendamento. Caso a variável tenha efeito significativo sobre o valor do arrendamento para culturas e aluguel de pasto, espera-se que esta relação seja positiva.

$\mathrm{Na}$ Figura 4 apresenta-se a evolução do volume de subsídio concedido a produtores e a cooperativas do estado de São Paulo, através do Sistema Nacional de Crédito Rural, de 1969 a 2001. Os valores negativos indicam o custo do crédito rural concedido naquele ano ao produtor ou à cooperativa. Tais valores referem-se aos anos em que a taxa de juros real do crédito rural não foi negativa. 


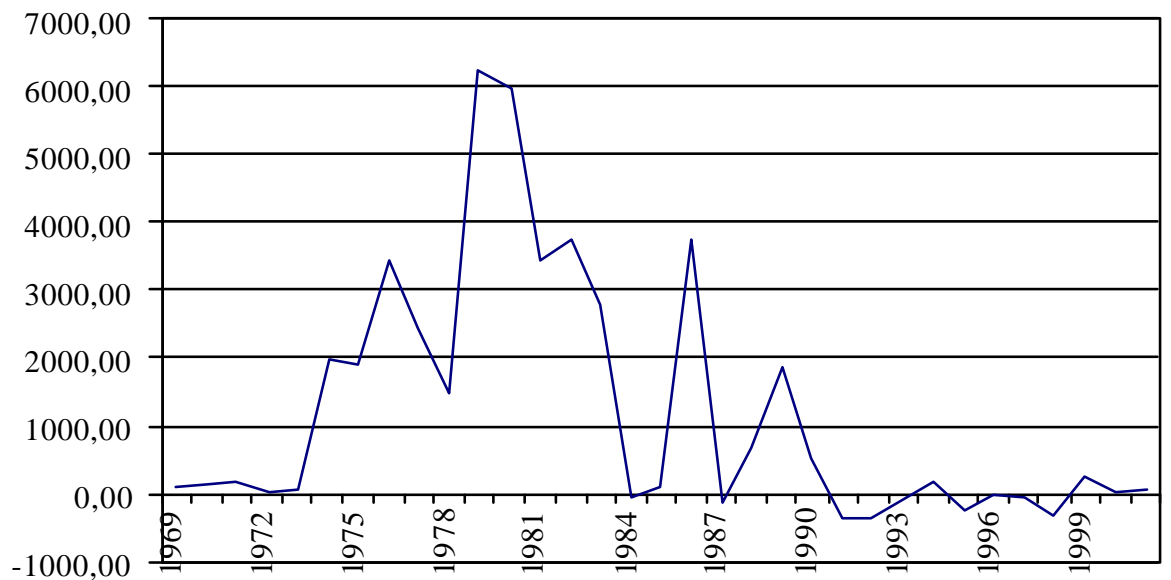

Figura 4 - Evolução do volume de subsídio concedido a produtores e cooperativas do estado de São Paulo, pelo Sistema Nacional de Crédito Rural, de 1969 a 2001.

Fonte: Resultados da pesquisa.

$\mathrm{O}$ índice de preços recebidos deve apresentar sinal positivo em todas as regressões, pois representa a renda bruta que o agricultor pode auferir com a terra. Já o índice de preços pagos pode apresentar tanto sinal positivo quanto negativo. É fácil entender o significado da relação negativa: quanto maiores forem os custos da atividade para o produtor, menor deverá ser a demanda por terra para fins agrícolas (mantendo constantes as demais variáveis). Contudo, se a relação entre IPP e preço de venda ou de arrendamento de terra for positiva, pode-se dizer que ocorre a substituição de insumos por terra, assim como notaram Dias, Vieira e Amaral (2001). O índice de paridade ou termos de troca deve apresentar relação direta com os preços de venda de terras e de arrendamento. A evolução destes índices é mostrada a seguir, na Figura 5. 


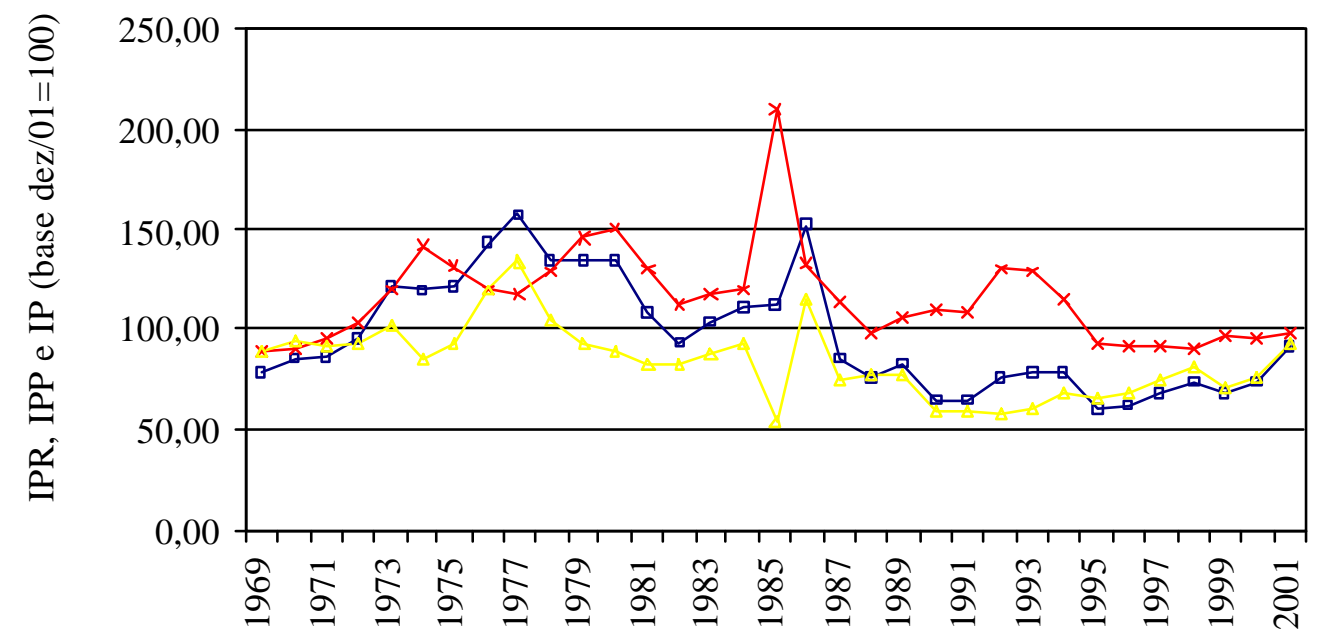

$\rightarrow$ IPR deflacionado dez $01 \quad \rightarrow$ IPP deflacionado dez 01

IP $\operatorname{dez} 01=100$

Figura 5 - Evolução dos Índices de Preços Recebidos, Preços Pagos e de Paridade para o estado de São Paulo, de 1969 a 2001.

Fonte: IEA

A variável poder de compra do agricultor, assim como os Índices de Preços Recebidos pelo produtor e de Paridade, deve apresentar relação positiva com todos os preços de terra a serem analisados. Ressalta-se que, além do índice de paridade, esta variável é composta por um índice de produtividade, o qual está diretamente ligado à evolução da rentabilidade do hectare da terra, uma vez que a produtividade da terra vem crescendo ao longo dos anos, principalmente a partir da década de 80 (vide Dias, Vieira e Amaral, 2001).

É válido realçar que o conjunto de variáveis IPR e IPP, e as variáveis IP e PC, são mutuamente exclusivos, ou seja, utilizando-se IPR e IPP em uma regressão, excluem-se IP e PC. De maneira semelhante, ao adotar-se IP, excluem-se IPR, IPP e PC. Optando-se por PC, as variáveis IPR, IPP e IP são eliminadas da análise. A explicação para este fato é que todas estas variáveis têm o intuito de captar o mesmo efeito sobre os 
preços de venda de terras e de arrendamentos: a rentabilidade da atividade agrícola. A Figura 6 mostra a evolução do índice de poder de compra do agricultor.

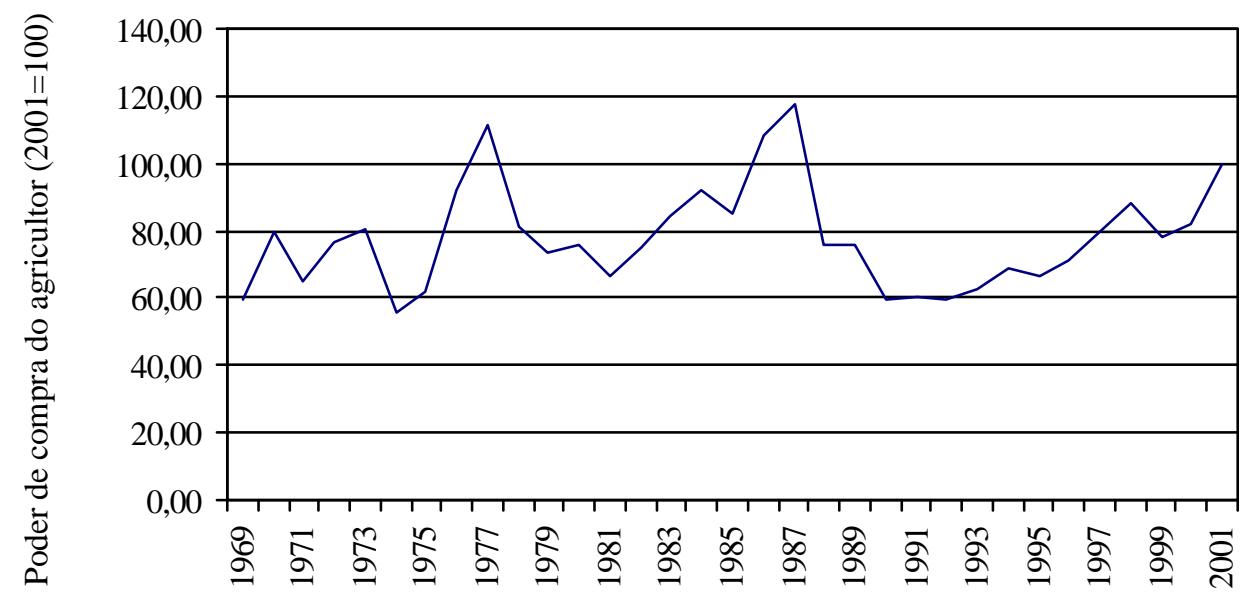

Figura 6 - Evolução do poder de compra do agricultor no estado de São Paulo, de 1969 a 2001.

Fonte: Resultados da pesquisa.

O efeito da taxa de inflação sobre os preços de venda da terra e do arrendamento foi muito discutido na literatura. Enquanto alguns autores verificaram que os preços da terra elevaram-se, em resposta à alta inflacionária, outros notaram que a relação entre estas variáveis pode ser oposta, com a condição de que exista algum ativo mais atrativo que a terra que traga rendimentos acima da taxa de inflação. Neste trabalho, porém, esperou-se encontrar uma relação positiva entre preços de venda da terra de cultura e de pastagem e taxa de inflação. Quanto aos valores de arrendamento e aluguel, caso exista alguma relação significativa entre estas variáveis e a taxa de inflação, espera-se que seja de pequena magnitude. O comportamento da taxa de inflação, no período em análise, apresenta-se na Figura 7. 


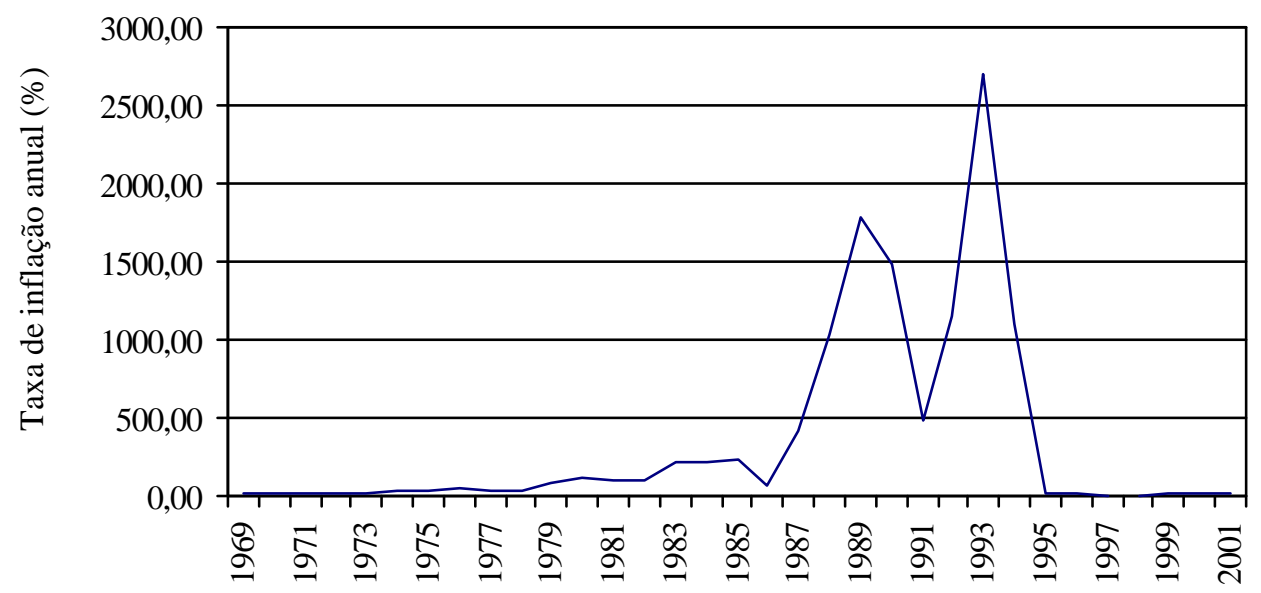

Figura 7 - Evolução da taxa de inflação anual, medida pela variação de dezembro a dezembro do IGP-DI (base ago 94 = 100), de 1969 a 2001.

Fonte: IPEA (2002)

De todas as variáveis em análise, o efeito do hiato do produto sobre os preços da terra foi a fonte das maiores controvérsias em estudos empíricos e teóricos da literatura consultada. Muitos autores afirmaram que, por ser a agricultura uma atividade como outra qualquer e que, portanto, depende da taxa de juros de mercado, a demanda por terra e, conseqüentemente, seus preços, devem manter uma relação direta com o Produto Interno Bruto. Outros, contrariamente, argumentaram que deve haver uma relação inversa entre nível de atividade econômica e preços de terra, uma vez que a atividade agrícola apresenta renda praticamente constante em quaisquer fases do ciclo econômico. Com isso, não há uma hipótese clara a ser formulada sobre a relação entre os preços de venda e valor de arrendamento da terra e hiato do produto. A Figura 8 mostra a evolução da proxy do hiato do produto para São Paulo, de 1969 a 2001.

Cabe ressaltar que a definição de hiato do produto adotada foi: produto efetivo menos produto tendencial (tendência do produto) divididos pelo produto tendencial. Desta forma, os valores negativos observados referem-se aos anos nos quais o produto 
efetivo foi menor que o de tendência, ou seja, a economia não operou em plena atividade em tais anos.

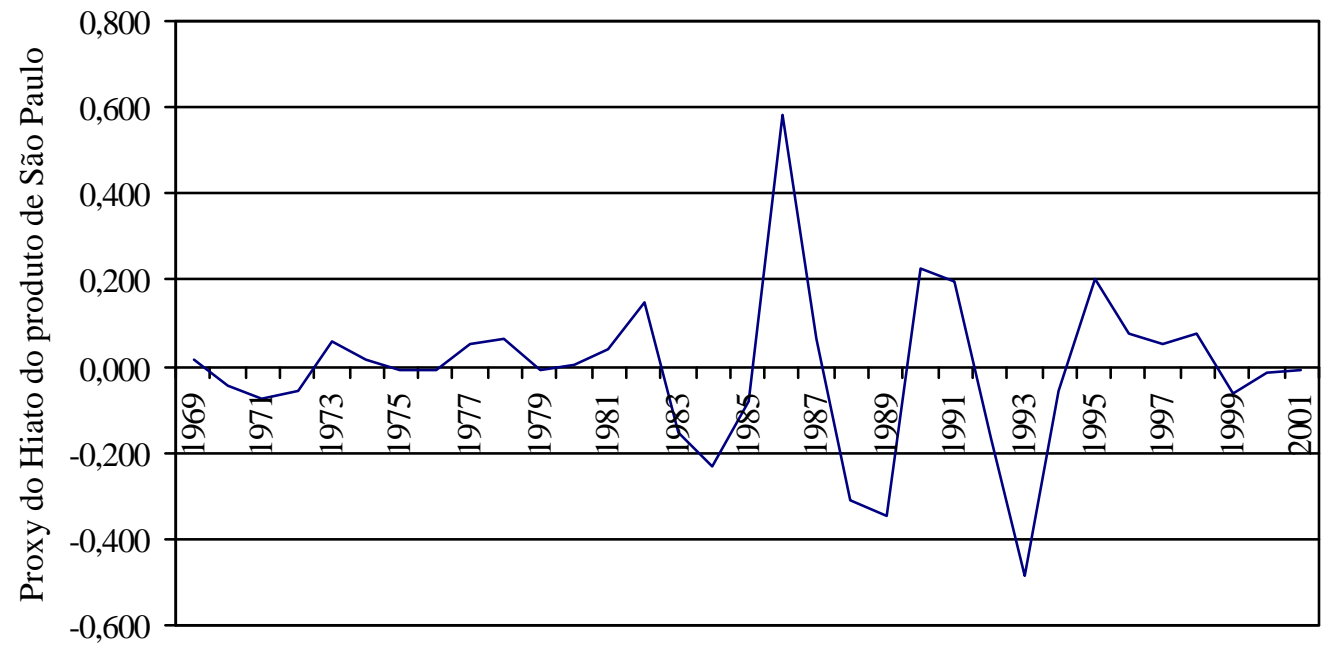

Figura 8 - Evolução da proxy do hiato m produto do estado de São Paulo, de 1969 a 2001.

Fonte: Resultados da pesquisa.

O comportamento da taxa de juro real (Selic) pode ser visto na figura 9. A hipótese subjacente a esta variável é que ela apresente uma relação inversa com os preços de venda da terra (de cultura e pastagem) e também com os preços de arrendamento (cultura e pasto). A idéia é que a taxa de juro real reflita o custo de oportunidade do dinheiro. Assim, quanto mais alta for essa taxa, menos vantajoso é o investimento em terras, na atividade agrícola ou em qualquer outra atividade, ceteris paribus. 


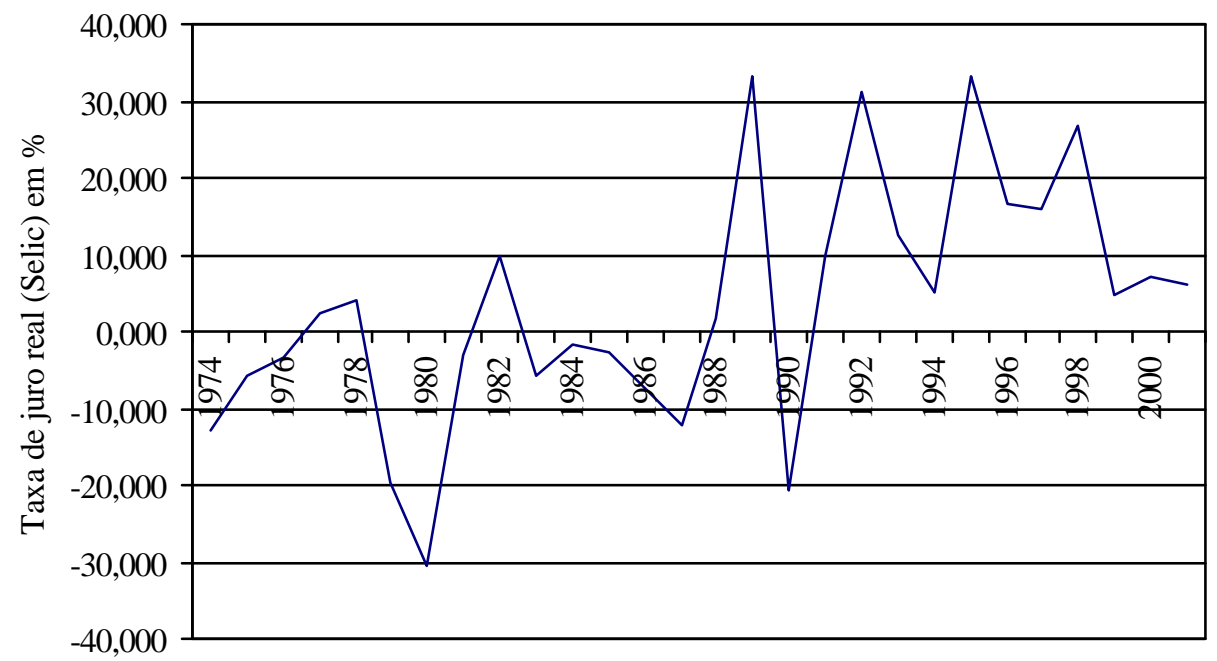

Figura 9 - Evolução da taxa de juro real (Selic) em \%, de 1974 a 2001.

Fonte: Resultados da pesquisa.

A evolução da extensão da rede rodoviária total pode ser vista na Figura 10. O comportamento dos preços de terra perante esta variável é incerto, como explicitado anteriormente. Novamente, pode-se pensar no caso da construção (ou melhoria) de uma estrada que ligue uma certa área fértil (área A) a uma outra área com mesma fertilidade, porém, esta última estando ao redor de um centro consumidor (área B), ocasionando variações nos preços de terras em sentidos diferentes. Os preços de terra na região A elevam-se, uma vez que aumentam os preços pagos ao produtor. Já os preços de terra na área B sofrem queda, uma vez que os preços pagos ao produtor, nesta região, diminuem.

Contudo, a hipótese a ser testada é que os preços de terra respondam positivamente a investimentos em infra-estrutura e, portanto, em rodovias. $\mathrm{O}$ argumento é que as estradas facilitam o escoamento da produção, reduzindo o custo do transporte e, conseqüientemente, aumentando os preços recebidos pelo produtor. 


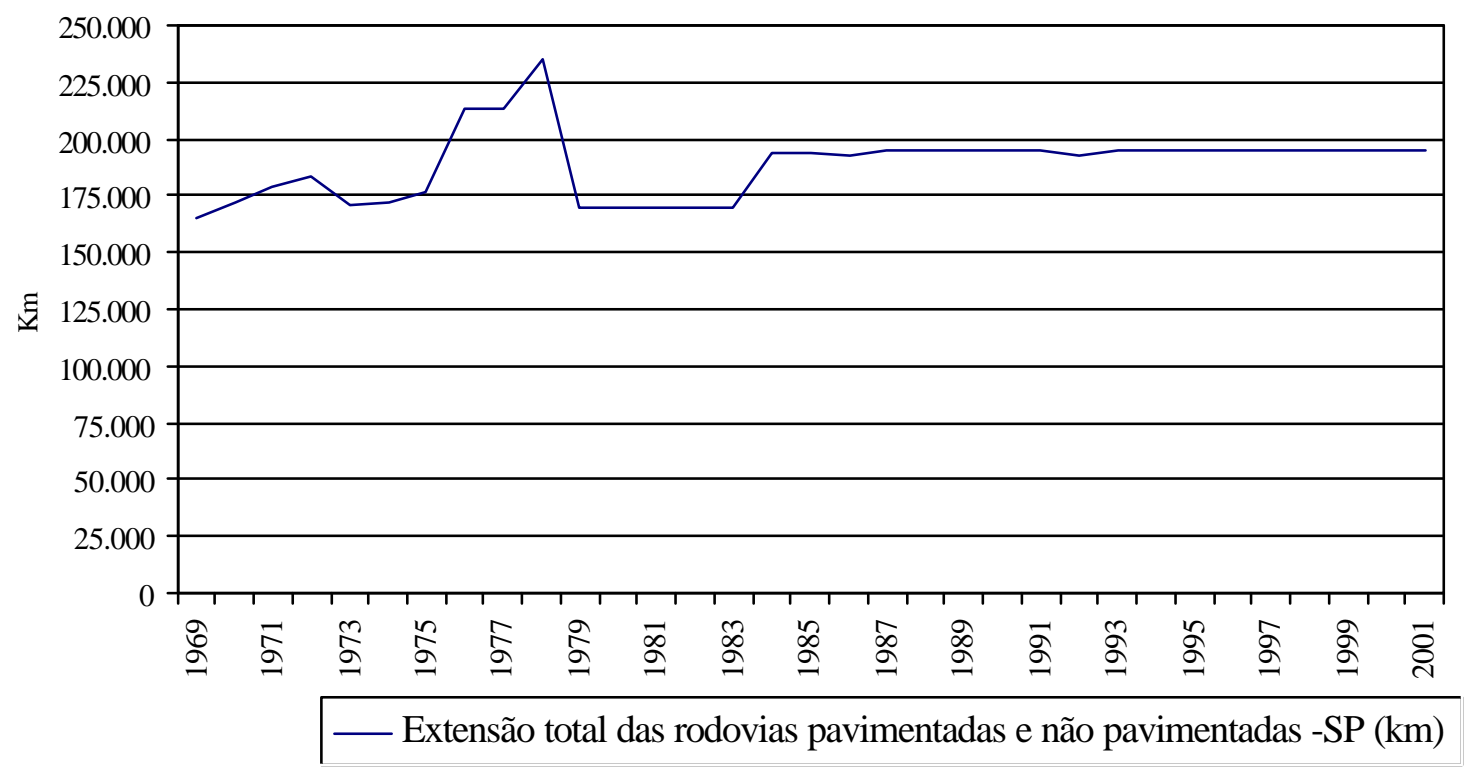

Figura 10 - Extensão da rede rodoviária total (pavimentada e não pavimentada - redes federal, estadual e municipal) do estado de São Paulo, em quilômetros.

Fonte: GEIPOT

Com relação à variável binária, espera-se que ela tenha um efeito positivo nas regressões a serem estimadas, resultando em deslocamento do intercepto para cima, no período de 1973 a 1994, já que empiricamente notou-se este fato.

Os preços de terra das diferentes categorias existentes no estado de São Paulo apresentaram comportamento semelhante ao longo do período analisado, conforme mostra a Figura 11.

Desta forma, espera-se que os preços de terras de cultura de primeira, de cultura de segunda, de pastagem, reflorestamento e campos sejam co-integrados, ou seja, que exibam comportamento de equilíbrio estável de longo prazo. 


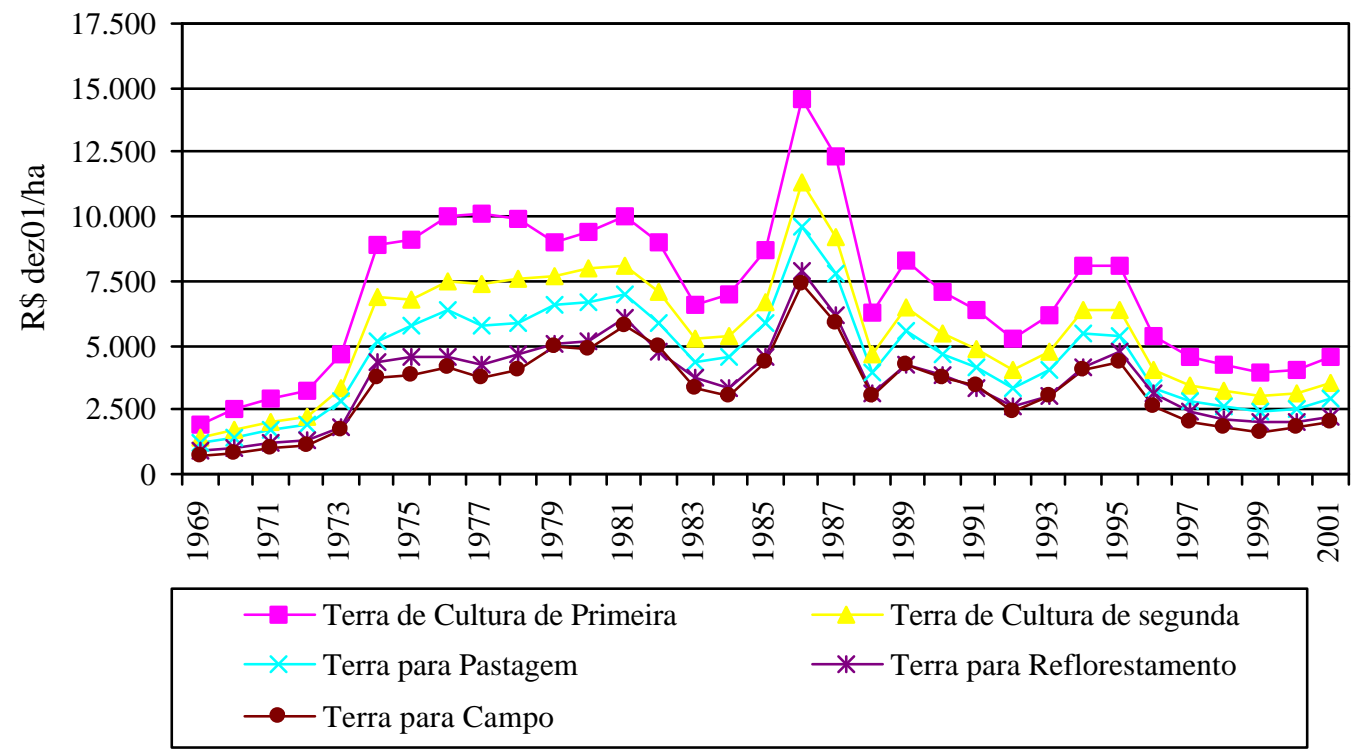

Figura 11 - Preços das terras de cultura de primeira, de segunda, de pastagem, de reflorestamento e de campo, no estado de São Paulo, de 1969 a 2001.

Fonte: IEA

Os preços de terra de lavoura e pastagem nos estados em análise apresentaram comportamento semelhante ao dos preços de terra de cultura de primeira e de pastagem no estado de São Paulo, assim como no caso dos preços de diferentes categorias de terra dentro do estado de São Paulo (vide Figura 12). Desta maneira, espera-se que os preços de terra de lavoura e de pastagem dos estados do Centro-Sul em estudo sejam cointegrados com os preços de terra de cultura de primeira e de pastagem, no estado de São Paulo. 


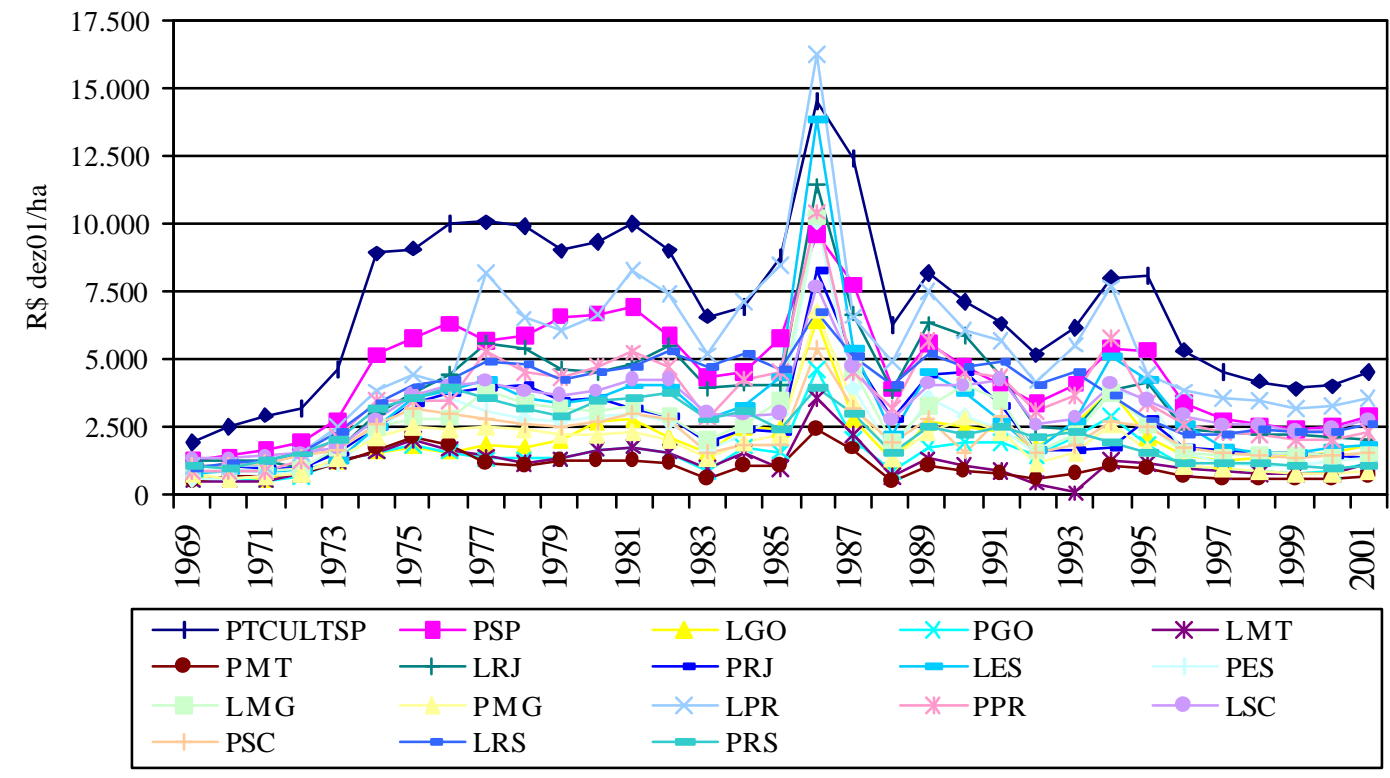

Figura 12 - Preços de terra de cultura de primeira e de pastagem, no estado de São Paulo, de lavoura e de pastagem, nos estados de Goiás, Mato Grosso, Rio de Janeiro, Espírito Santo, Minas Gerais, Paraná, Santa Catarina e Rio Grande do Sul, de 1969 a 2001.

Fonte: IEA e FGV

A hipótese de as variáveis serem co-integradas (tanto para os preços de terra dentro do estado como entre os estados) faz sentido tanto do ponto de vista do setor agrícola como sob a ótica macroeconômica.

Primeiramente, sabe-se que existe mobilidade dos indivíduos que demandam terra com finalidade agrícola. Esta mobilidade pode se dar tanto dentro de um estado (na medida que as terras mais férteis vão tornando-se escassas) como entre estados ou regiões (inovações agronômicas tornando aptas as terras anteriormente inaptas ao cultivo). O cerrado brasileiro é um exemplo dessa migração.

Uma outra possível justificativa para que os preços de terra dentro do estado e entre estados sejam co-integrados é de origem macroeconômica. Os anos de alta 
inflacionária, mercado financeiro pouco estruturado e incerteza quanto aos planos econômicos criaram uma demanda por terras com finalidade especulativa, como mostraram os estudos referenciados. Muitos agentes sem envolvimento com a atividade agropecuária passaram a demandar terras, nessas fases, com a finalidade de reserva de valor. 


\section{RESULTADOS E DISCUSSÃO}

Objetiva-se primeiramente, neste capítulo, estimar regressões para os determinantes dos preços de venda da terra de cultura de primeira, da terra de pastagem, valor do arrendamento para cultura e aluguel de pasto, e discutir os principais resultados obtidos. Para tanto, foram utilizadas as variáveis descritas no capítulo anterior e, com base nas pressuposições do modelo clássico de regressão linear descritas previamente, optou-se por aqueles modelos que melhor representaram as hipóteses descritas no subitem 3.2.1.2.

Em seguida, estão apresentados os resultados dos testes de raiz unitária e cointegração, seguindo a metodologia descrita no capítulo anterior. Para cada uma das séries discutidas no subitem 3.2.1.1.2 fez-se um teste de raiz unitária. Já a co-integração foi testada entre os preços de terra das diferentes categorias, dentro do estado de São Paulo, e entre os preços de terra de cultura de primeira e de pastagem, em São Paulo e em cada um dos estados do Centro-Sul (com exceção dos estados do Tocantins e de Mato Grosso do Sul), no total de 9 testes de co-integração.

Inicialmente, foram mostrados os resultados obtidos pelas regressões para os preços de venda da terra. Fez-se uma análise dessas regressões para, em seguida, serem discutidos os resultados. Ressalta-se que, para a análise das relações entre as variáveis dependentes e explicativas de cada regressão, como todos os modelos estão na forma linear, optou-se por construir as elasticidades médias de cada variável explicativa com relação à dependente, em cada uma das regressões. Posteriormente, são analisados os preços de arrendamento, seguindo o mesmo procedimento. 
Os dois últimos itens deste capítulo apresentam os resultados dos testes de raiz unitária das séries mencionadas anteriormente e, em seguida, de co-integração entre as variáveis já explicitadas. São analisados cada um dos testes e, em seguida, há o comentário sobre os resultados obtidos.

\subsection{Resultados obtidos pelas regressões dos preços de venda das terras de cultura de primeira e de pastagem}

Segundo a teoria econômica, o preço da terra deve refletir o valor presente dos fluxos de receitas que este fator pode gerar. Sendo assim, a Tabela 1 traz uma comparação entre os resultados obtidos de duas regressões lineares simples que almejam representar esse conceito. A primeira delas tem como variável dependente a relação entre arrendamento para culturas e preço da terra de cultura de primeira (no estado de São Paulo). Na segunda regressão, a variável dependente é a relação entre aluguel de pastos e preço de venda da terra para pastagem (estado de São Paulo). A variável explicativa das duas regressões é a taxa de juro real (Selic).

Tabela 1. Resultados obtidos pelas regressões: relação entre arrendamento de terra para cultura e preço de terra de cultura de primeira, relação entre aluguel de pastos e preço de venda de terra de pastagem, ambas em função da taxa de juro.

\begin{tabular}{ccc}
\hline & $\begin{array}{c}\text { Arrendamento de terras para } \\
\text { cultura/preço da terra de cultura de } \\
\text { primeira }\end{array}$ & $\begin{array}{c}\text { Aluguel de terras para } \\
\text { pastagem/preço da terra de } \\
\text { pastagem }\end{array}$ \\
\hline Análise de Regressão Linear & $\mathrm{F}=0,020$ & $\begin{array}{c}\mathrm{F}=0,03 \\
\mathrm{R}^{2}=0,001\end{array}$ \\
\hline Variável & & Coeficientes \\
\hline Constante & $0,04^{*}(29,35)$ & $0,03^{*}(29,90)$ \\
TJ & $0,00001(0,14)$ & $0,00001(0,17)$ \\
\hline
\end{tabular}

Fonte: Resultados da pesquisa.

Notas: Os valores da estatística t encontram-se entre parênteses;

* significativo a $1 \%$;

** signific ativo a $5 \%$;

*** significativo a $10 \%$.

Os modelos em análise e também seus coeficientes individualmente não mostraram significância estatística, como pode ser visto pelos resultados dos testes $\mathrm{F}$ e t. 
O coeficiente de determinação das duas regressões não mostrou um bom ajuste entre as variáveis em questão.

Uma vez que os resultados dos testes $\mathrm{F}$, $\mathrm{t}$ e do coeficiente de determinação não foram satisfatórios, não foram analisadas nem a auto-correlação de resíduos nem a heterocedasticidade. Considerou-se desnecessário calcular a elasticidade da taxa de juro com relação às variáveis dependentes, uma vez que os coeficientes da variável explicativa não foram significativos.

Os resultados obtidos pelas regressões da Tabela 1 não foram condizentes com o esperado. A relação entre arrendamento e preço da terra deveria mostrar alguma correlação com a taxa de juro real, segundo a teoria econômica. Embora os resultados não tenham sido satisfatórios, não se pode dizer que essas variáveis não tenham relação. Uma possível explicação para os resultados obtidos é que a taxa de juro Selic pode não ter sido uma medida adequada da taxa de juro de mercado, a qual deveria refletir o custo de oportunidade da terra ou do investimento no setor agrícola.

A Tabela 2 traz uma comparação entre os resultados das regressões dos preços de venda da terra de cultura de primeira e de pastagem, em função das mesmas variáveis explicativas, as quais são: volume de subsídio concedido através do crédito rural, poder de compra do agricultor, logaritmo da taxa de inflação e hiato do produto. 
Tabela 2. Influência do volume de subsídio concedido através do crédito rural, poder de compra do agricultor, taxa de inflação e hiato do produto na determinação dos preços de venda de terra de cultura de primeira e terra de pastagem.

\begin{tabular}{|c|c|c|}
\hline & Preço da terra de cultura de primeira & Preço da terra de pastagem \\
\hline Análise de Regressão Linear & $\begin{array}{c}\mathrm{F}=17,27^{*} \\
\mathrm{R}^{2}=0,71\end{array}$ & $\begin{array}{l}\mathrm{F}=20,85^{*} \\
\mathrm{R}^{2}=0,75\end{array}$ \\
\hline Variáveis & \multicolumn{2}{|c|}{ Coeficientes } \\
\hline Constante & $2411,25^{*}(1,33)$ & $1480,81(1,30)$ \\
\hline $\mathrm{PC}$ & $65,30^{*}(3,26)$ & $37,42^{*}(2,98)$ \\
\hline VCRSUB & $0,70^{*}(4,11)$ & $0,53^{*}(4,96)$ \\
\hline LTINF & $1910,04^{*}(4,70)$ & $1333,69^{*}(5,23)$ \\
\hline HIATO & $6564,98^{*}(3,60)$ & $4281,36^{*}(3,75)$ \\
\hline
\end{tabular}

Fonte: Resultados da pesquisa.

Notas: Os valores da estatística t encontram-se entre parênteses;

*significativo a $1 \%$;

*** significativo a $5 \%$;

${ }^{* * *}$ significativo a $10 \%$.

Os dois modelos em análise mostraram-se altamente significativos (1\%), como pode ser visto pelo resultado do teste F. Os coeficientes de determinação obtidos indicaram que os modelos apresentaram bons ajustes.

As Tabelas com os valores de $d$ (Durbin-Watson) e $\chi^{2}$ (teste de heterocedasticia de White) calculados, assim como a matriz de correlação simples das variáveis explicativas encontram-se nos Anexos F e G, respectivamente.

Não se observou auto-correlação positiva nos resíduos. Entretanto, seguindo o teste de Durbin-Watson, os valores de $d$ calculados enquadram-se na área de indecisão. Embora esses resultados possam comprometer a eficiência dos estimadores, não acarretam em viés e, portanto, não prejudicam substancialmente a análise.

Quanto à variância dos termos de erro, não se rejeitou a hipótese de homocedasticidade em ambas as regressões, considerando o nível de significância de $5 \%$.

As variáveis explicativas não apresentam relação linear, segundo a matriz de correlação simples. $O$ mais alto coeficiente de correlação encontrado foi entre as 
variáveis hiato do produto e logaritmo da taxa de inflação $(r=0,39)$. Contudo, este valor não representa um problema sério de multicolinearidade. Conforme mencionado no capítulo anterior, um coeficiente de correlação simples igual ou superior a 0,8 é indício de um problema sério de multicolinearidade.

Os resultados das elasticidades médias, calculadas para as variáveis explicativas em relação às dependentes, encontram-se na Tabela 3.

Tabela 3. Elasticidades médias das variáveis explicativas em relação aos preços de venda da terra de cultura e de pastagem.

\begin{tabular}{ccc}
\hline Variáveis & Preço da terra de cultura de primeira & Preço da terra de pastagem \\
\hline PC & 0,723 & 0,644 \\
VCRSUB & 0,185 & 0,140 \\
LTINF & 0,508 & 0,551 \\
HIATO & 0,007 & 0,007 \\
\hline
\end{tabular}

Fonte: Resultados da pesquisa.

Nota: $\mathrm{O}$ cálculo das elasticidades médias corresponde à fórmula: $\varepsilon=$ (inclinação)*( $\left.\mathrm{X}_{\text {médio }} / \mathrm{Y}_{\text {médio }}\right)$, sendo $\mathrm{X}$ a variável explicativa e $\mathrm{Y}$ a variável explicada.

Analisando-se simultaneamente as duas regressões, nota-se que o poder de compra do agricultor foi a variável com maior valor de elasticidade com relação aos preços de terra desta categoria. A elevação de $10 \%$ no poder de compra do agricultor elevou, em média, os preços da terra de cultura de primeira em $7,23 \%$, e os preços de terra para pastagem em $6,44 \%$.

A taxa de inflação foi o segundo componente que exerceu maior influência nos preços de venda de terra destas duas categorias. A variação de $10 \%$ dessa taxa levou a uma variação diretamente proporcional nos preços dos fatores de produção em estudo, na ordem de $5,08 \%$ (para culturas) e de 5,51\% (para pastagem).

A elasticidade média do volume de subsídio com relação ao preço da terra de cultura foi de 0,185 e com relação ao preço da terra de pastagem foi de 0,14 . Deste modo, a elevação ou a queda de $10 \%$ no volume de subsídio fez com que os preços das 
terras destas categorias variassem, respectivamente, $1,85 \%$ e 1,40\%, em média, e no mesmo sentido da variação do subsídio.

A variável com menor elasticidade com relação à variação wos preços da terra de cultura e terra de pastagem foi o hiato do produto, além de manter uma relação inversa com as variáveis em questão. O aumento de $10 \%$ no hiato do produto (considerando que a média dessa variável, no período, foi negativa) provocou uma queda de, em média, 0,07\% nos preços da terra de cultura e da terra de pastagem. Vale relembrar que, pela definição do hiato do produto, o aumento deste hiato, sendo ele negativo, corresponde à diminuição do PIB efetivo (ou aumento do PIB potencial), ou seja, ao desaquecimento da economia. Nota-se, portanto, o comportamento pró-cíclico dos preços da terra, conforme levantado por Pinheiro (1980), Castro (1981), Pinheiro e Reydon (1981), Sayad (1982), Brandão e Rezende (1989), Romeiro e Reydon (1994) e Reydon e Plata (2000).

Na Tabela 4 há uma comparação entre os resultados obtidos das regressões dos preços de venda da terra de cultura de primeira e de pastagem, sendo explicadas pelas mesmas variáveis independentes, as quais são: poder de compra do agricultor, volume de subsídio concedido através do crédito rural, hiato do produto e variável binária. 
Tabela 4. Influência do poder de compra do agricultor, do volume de subsídio concedido através de crédito rural, do hiato do produto e da variável binária (para o período 1973-95) sobre os preços da venda de terra de cultura de primeira e terra de pastagem.

\begin{tabular}{|c|c|c|}
\hline & Preço da terra de cultura de primeira & Preço da terra de pastagem \\
\hline Análise de Regressão & $\begin{array}{l}\mathrm{F}=24,73^{*} \\
\mathrm{R}^{2}=0,779\end{array}$ & $\begin{array}{l}\mathrm{F}=23,46^{*} \\
\mathrm{R}^{2}=0,770\end{array}$ \\
\hline Variáveis & \multicolumn{2}{|c|}{ Coeficientes } \\
\hline Constante & $144,60(0,10)$ & $402,21(0,41)$ \\
\hline $\mathrm{PC}$ & $50,81^{*}(2,91)$ & $27,52^{* *}(2,30)$ \\
\hline VCRSUB & $0,3246^{* * *}(1,93)$ & $0,2981^{* *}(2,59)$ \\
\hline HIATO & $5095,49^{*}(3,40)$ & $3145,05^{*}(3,06)$ \\
\hline BIN & $3870,24^{*}(6,12)$ & $2473,89^{*}(5,70)$ \\
\hline
\end{tabular}

Fonte: Resultados da pesquisa.

Notas: Os valores da estatística t encontram-se entre parênteses;

*significativo a $1 \%$;

${ }^{* *}$ significativo a $5 \%$;

**** significativo a $10 \%$.

Os dois modelos em análise mostraram-se altamente significativos (1\%), como pode ser visto pelo resultado do teste $\mathrm{F}$, com coeficientes também significativos. Os coeficientes de determinação obtidos mostraram-se muito semelhantes.

As Tabelas com os valores de $d$ (Durbin-Watson) e $\chi^{2}$ (teste de heterocedasticia de White) calculados, assim como a matriz de correlação simples das variáveis explicativas encontram-se nos Anexos $\mathrm{He} \mathrm{I}$, respectivamente.

Não se observou auto-correlação positiva nos resíduos. Entretanto, seguindo o teste de Durbin-Watson, os valores de $d$ calculados enquadram-se na área de indecisão.

Com relação à variância dos termos de erro, não se rejeitou a hipótese de homocedasticidade em ambas as regressões.

As variáveis explicativas especificadas não apresentam relação linear, conforme a matriz de correlação simples. O mais alto coeficiente de correlação foi encontrado entre a variável binária e o volume subsídio creditício concedido $(r=0,46)$. Contudo, este valor não é considerado um problema de multicolinearidade. 
As elasticidades médias calculadas para interpretação das relações entre as variáveis explicativas e dependentes encontram-se na Tabela 5.

Tabela 5. Elasticidades médias das variáveis explicativas em relação aos preços da venda de terras de cultura e de pastagem.

\begin{tabular}{ccc}
\hline Variáveis & Preço de terra de cultura de primeira & Preço de terra de pastagem \\
\hline PC & 0,5627 & 0,4733 \\
VCRSUB & 0,0553 & 0,0789 \\
HIATO & 0,0055 & 0,0053 \\
BIN & $0,9371^{*}$ & $0,9633^{*}$ \\
\hline
\end{tabular}

Fonte: Resultados da pesquisa.

*Esse resultado corresponde à variação relativa do valor do arrendamento para culturas quando a binária passa de 0 a 1.

O componente que exerce maior influência sobre a determinação dos preços de venda das duas categorias de terras consideradas, dada uma variação idêntica em todas as variáveis, foi, assim como nas regressões que constam nas Tabelas 2 e 3 , o poder de compra do agricultor. $\mathrm{O}$ aumento de $10 \%$ nesta variável levou ao aumento dos preços de venda da terra de cultura e da terra de pastagem em 5,6\% e 4,7\%, respectivamente.

O volume de subsídio concedido contribuiu com a alteração dos preços destes fatores de produção, variando os preços da terra de altura e de pastagem, em média, $0,55 \%$ e $0,78 \%$, respectivamente, dada uma variação de $10 \%$ no volume de subsídio concedido.

O último componente a ser comentado é o hiato do produto que, assim como nas regressões anteriores, exerceu menor influência na determinação dos preços destes fatores produtivos, além de ter sido o único a oscilar em sentido contrário ao dos preços da terra. A variação de $10 \%$ do hiato do produto alterou, em média e em sentido contrário, $0,055 \%$ e $0,054 \%$ os preços de venda das terras de lavoura e pastagem, respectivamente.

Quanto à variável binária, nota-se que tanto os preços de venda da terra de cultura como os de terra para pastagem mostraram elevação significativa no período de 1973-94. Os preços de venda da terra de cultura de primeira elevaram-se, em média, 
93,71\% nos anos de 1973-94, com relação à média destes preços nos períodos 1969-72 e 1995-01. Os preços de venda de terra de pastagem elevaram-se ainda mais, segundo os resultados obtidos: $96,33 \%$.

Há ainda três regressões estimadas para os preços de venda da terra de cultura e de pastagem. A primeira a ser apresentada é relativa à terra de cultura e inclui na análise a variável extensão da rede rodoviária do estado de São Paulo (proxy para infraestrutura). As regressões seguintes referem-se à terra de pastagem, sendo que a primeira incorpora a variável rodovias na análise; enquanto que a segunda, a taxa de juro real. As três regressões são explicadas por diferentes variáveis. Os resultados da regressão para terra de cultura podem ser vistos na Tabela 6.

Tabela 6. Influência do índice de preços recebidos pelos produtores, índice de preços pagos pelos produtores (ambos defasados em um período), taxa de inflação, hiato do produto e extensão da rede rodoviária do estado de São Paulo sobre os preços da venda de terra de cultura de primeira.

\begin{tabular}{cc}
\hline \multirow{2}{*}{ Análise de Regressão } & Preço da terra de cultura de primeira \\
\cline { 2 - 2 } & $\mathrm{F}=43,35^{*}$ \\
$\mathrm{R}^{2}=0,89$ \\
\hline Variáveis & Coeficientes \\
\hline Constante & $10.621,04^{*}(4,06)$ \\
IPR ( 1) & $40,841^{*}(5,09)$ \\
IPP $(1)$ & $56,428^{*}(4,83)$ \\
LTINF & $790,327^{*}(2,72)$ \\
HIATO & $3.049,357^{* *}(2,32)$ \\
RODO & $0,031^{* * *}(2,48)$ \\
\hline
\end{tabular}

Fonte: Resultados da pesquisa.

Notas: Os valores da estatística t encontram-se entre parênteses;

"significativo a $1 \%$;

***ignificativo a $5 \%$;

*** significativo a $10 \%$.

A análise de regressão desta equação estimada encontra-se muito próxima daquelas descritas anteriormente. O modelo, assim como os parâmetros, são altamente significativos. O coeficiente de determinação obtido indicou que o modelo foi bem ajustado. 
A variável binária construída com a finalidade de corrigir a distorção dos dados referentes à extensão das rodovias do estado de São Paulo (BINR) não se mostrou significativa. Desta maneira, excluiu-se tal variável da análise.

As Tabelas com os valores de $d$ (Durbin-Watson) e $\chi^{2}$ (teste de heterocedasticia de White) calculados, assim como a matriz de correlação simples das variáveis explicativas encontram-se nos Anexos J e K, respectivamente.

Não se rejeitou a hipótese de homocedasticidade dos termos de erro. Quanto à auto-correlação dos resíduos, o valor $d$ calculado de Durbin-Watson encontra-se na área inconclusiva. Os coeficientes de correlação entre as variáveis explicativas não indicaram a presença de multicolinearidade, sendo que o maior coeficiente obtido foi entre os Índices de Preços Recebidos e de Preços Pagos, com valor igual a 0,57.

A Tabela 7 apresenta os resultados das elasticidades calculadas para as variáveis explicativas consideradas, em relação ao preço da terra de cultura de primeira.

Tabela 7. Elasticidades médias das variáveis explicativas em relação aos preços da venda de terra de cultura de primeira.

\begin{tabular}{cc}
\hline Variáveis & Preço da terra de cultura de primeira \\
\hline IPR( 1$)$ & 0,5506 \\
IPP( 1$)$ & 0,9116 \\
LTINF & 0,1098 \\
HIATO & 0,0035 \\
RODO & 0,8070 \\
\hline
\end{tabular}

Fonte: Resultados da pesquisa.

Os principais determinantes do preço da venda de terra de cultura de primeira, segundo os resultados apresentados nas Tabelas 6 e 7, são os índices de preços recebidos e preços pagos pelos agricultores, defasados em um período.

Em média, o aumento de $10 \%$ no índice de preços pagos em um determinado ano elevou o preço da terra de cultura de primeira em 9,12\%, no ano seguinte. Para a interpretação da relação direta observada entre o índice de preços pagos e preço de 
venda da terra de cultura de primeira, é preciso uma explanação prévia sobre a composição deste índice.

Consta que o item "arrendamentos pagos" é um componente da estrutura de ponderação para o cálculo do índice em análise, embora tenha pequena participação. Outro componente do índice de preços pagos, este com maior participação, são os adubos e corretivos que funcionam como substitutos à terra. A participação de arrendamentos pagos no cálculo deste ńdice foi de 2,17\%, em 1968/69 e, em 1980/81, aumentou para 3,07\%. Já a participação de adubos e corretivos passou de 10,34\%, em $1968 / 69$ para $16,12 \%$, em $1980 / 81^{20}$.

Desta maneira, um possível argumento a favor da relação positiva entre o índice de preços pagos e preço da terra de cultura é que o índice de preços pagos, tendo em sua composição fatores que influenciam positivamente os preços da terra, pode estabelecer uma relação direta com o preço desse fator produtivo.

O aumento de $10 \%$ nos preços pagos pelos agricultores em determinado ano elevou, em média, $5,51 \%$ os preços de venda deste tipo de terra no ano seguinte.

A variável associada à infra-estrutura do estado (RODO) teve grande influência sobre os preços de venda da terra de cultura, conforme mostraram os resultados da regressão em estudo. O aumento de $10 \%$ na extensão da malha rodoviária no estado resultou em elevação de $8,07 \%$ nos preços de venda da terra desta categoria.

A taxa de inflação e o hiato do produto exibiram valores de elasticidades com relação ao preço da terra de cultura menores que os índices de preços pagos, recebidos e extensão da malha rodoviária. Uma variação de $10 \%$ na taxa de inflação variou os preços da terra em $0,59 \%$, em média, e em mesmo sentido. A variação de $10 \%$ no hiato do produto ocasionou a alteração de $0,041 \%$ nos preços da terra, em sentido inverso.

${ }^{20}$ A estrutura de ponderação para cálculo de Índices de Preços Pagos pela agricultura paulista pode ser vista em IEA (1990a). 
Há ainda duas últimas considerações a serem feitas, quanto a esta regressão. Primeiramente, deve-se ter certa cautela quanto à análise das elasticidades desta regressão, uma vez que a variável que representa a infra-estrutura do estado contém valores superestimados, com relação ao restante da série.

Em segundo lugar, realça-se que a taxa de juro real não foi significativa em nenhuma das regressões testadas, exceto em uma. Nesta única regressão em que foi significativa, tal variável apresentou comportamento oposto ao esperado (apresentou elasticidade positiva com relação ao preço de venda da terra de cultura de primeira), possivelmente por um problema de multicolinearidade entre a taxa de juro real e o índice de preço recebido pelo produtor $(\mathrm{r}=0,63)$.

Contudo, Brandão e Rezende (1989) sugeriram que pode ter existido uma relação positiva entre preço da terra e taxa de juro, na fase em que foram concedidos grandes volumes de crédito rural subsidiado. Neste período, justificaram os autores, sendo a terra o aval para a obtenção desse crédito, o indivíduo que desejasse tomar crédito e não investir na agricultura, o faria e aplicaria à taxa de juro vigente no mercado financeiro. Assim, o aumento da taxa de juro levaria à maior demanda por crédito rural para investimento no mercado financeiro e, conseqüentemente, em maior demanda por terras.

Não obstante esse argumento seja coerente, o período de concessão abundante de subsídio é relativo a um terço do período estudado neste trabalho. Assim, pode ser que esse argumento não justifique uma relação positiva entre preço da terra e taxa de juro. Além disso, nas demais regressões para o preço de venda da terra de cultura em que a taxa de juro real não foi significativa, a variável em questão comportou-se conforme o esperado, ou seja, em direção oposta ao comportamento dos preços de venda da terra de cultura de primeira. Ressalta-se ainda que embora a taxa de juro real não tenha sido significativa em nenhuma das equações regredidas, isso não significa que não exista relação entre tal variável e o preço da terra de cultura de primeira. 
São apresentadas, a seguir, duas regressões ajustadas para preço de venda da terra para pastagem. As Tabelas 8 e 10 incluem a variável infra-estrutura (representada pela extensão das rodovias do estado de São Paulo) enquanto que as Tabelas 12 e 14 incorporam a taxa de juro real à análise dos determinantes dos preços de terra para pastagem.

Tabela 8. Influência do índice de preços recebidos pelos produtores, índice de preços pagos pelos produtores (ambos defasados em um período), taxa de inflação, hiato do produto, extensão da malha rodoviária do estado de São Paulo e volume de subsídio creditício concedido, sobre os preços de venda de terra de pastagem.

\begin{tabular}{cc}
\hline \multirow{3}{*}{ Análise de Regressão Linear } & Preço da terra de pastagem \\
\cline { 2 - 2 } & $\mathrm{F}=33,67^{*}$ \\
$\mathrm{R}^{2}=0,89$ \\
\hline Variáveis \\
\hline Constante \\
IPR( 1) \\
IPP( 1) & $6330,14^{*}(3,43)$ \\
LTINF & $18,03^{*}(2,83)$ \\
HIATO & $36,90^{*}(4,27)$ \\
RODO & $625,94^{*}(3,07)$ \\
VCRSUB & $1.954,88^{* * *}(2,12)$ \\
\hline
\end{tabular}

Fonte: Resultados da pesquisa.

Notas: Os valores da estatística t encontram-se entre parênteses;

* significativo a $1 \%$;

${ }^{* *}$ significativo a $5 \%$;

${ }^{* * *}$ significativo a $10 \%$.

O modelo em análise mostrou-se altamente significativo (1\%), de acordo com o resultado do teste F. Além disso, apresentou coeficiente de determinação com valor relativamente alto, mostrando que o modelo foi bem ajustado. Os parâmetros mostraram-se significativos a, pelo menos, 10\%. Assim como na regressão anterior, a variável binária, incluída no estudo para corrigir a alteração na série de dados da extensão das rodovias do estado de São Paulo (BINR), não foi significativa. Optou-se, portanto, por excluir-se tal variável da equação. 
As Tabelas com os valores de $d$ (Durbin-Watson) e $\chi^{2}$ (teste de heterocedasticia de White) calculados, assim como a matriz de correlação simples das variáveis explicativas encontram-se nos Anexos L e M, respectivamente.

Não se observou auto-correlação positiva nos resíduos. Seguindo o teste de Durbin-Watson, o valor de $d$ calculado enquadra-se na área de indecisão. Quanto à variância dos termos de erro, não se rejeitou a hipótese de homocedasticidade.

As variáveis explicativas em análise não apresentam relação linear, segundo a matriz de correlação simples. O mais alto coeficiente de correlação foi obtido entre as variáveis índice de preços recebidos pelos produtores (defasado em um período) e volume de subsídio concedido via crédito rural $(\mathrm{r}=0,62)$.

Os resultados das elasticidades médias, calculadas para as variáveis explicativas em relação às dependentes, encontram-se na Tabela 9.

Tabela 9. Elasticidades médias das variáveis explicativas em relação aos preços de venda da terra de pastagem.

\begin{tabular}{cc}
\hline Variáveis & Preço da terra de pastagem \\
\hline $\operatorname{IPR}(1)$ & 0,3775 \\
$\operatorname{IPP}(1)$ & 0,9259 \\
LTINF & 0,1351 \\
HIATO & 0,0035 \\
RODO & 0,7578 \\
VCRSUB & 0,0506 \\
\hline
\end{tabular}

Fonte: Resultados da pesquisa.

Nota: $\mathrm{O}$ cálculo das elasticidades médias corresponde à fórmula: $\varepsilon=($ inclinação $) *\left(\mathrm{X}_{\text {médio }} / \mathrm{Y}_{\text {médio }}\right)$, sendo $\mathrm{X}$ a variável explicativa e Y a variável explicada.

Analisando a regressão dos determinantes dos preços da terra para pastagem, nota-se que o índice de preços pagos, defasado em um período, foi a variável com maior elasticidade em relação aos preços de terra desta categoria. A elevação de $10 \%$ nesta variável elevou, em média, os preços da terra de pastagem em 9,25\%. O comportamento direto desta variável com relação ao preço de venda da terra de pastagem não condiz com as expectativas; esperava-se uma variação dos preços do fator em questão em 
sentido contrário ao da variação do índice de preços pagos pelos produtores. Para a interpretação da relação direta observada entre índice de preços pagos e preço de venda da terra de pastagem utiliza-se o mesmo raciocínio exibido na regressão anterior.

A variação do preço de venda da terra para pastagem foi bastante sensível à variação da extensão da malha rodoviária do estado de São Paulo. Um aumento de $10 \%$ na extensão desta malha elevou os preços de venda da terra para pastagem, em média, 7,58\%. De maneira semelhante ao que foi ressaltado na regressão para preço de venda da terra de cultura de primeira, deve-se analisar com cautela esse resultado, uma vez que há problema nos dados desta variável, conforme explicitado no marcador $\mathrm{n}$ do subitem 3.2.1.1.1.

O índice de preços recebidos, também defasado em um período, foi o terceiro componente que exerceu maior influência sobre os preços de venda da terra para pastagem. A variação de $10 \%$ neste índice levou a uma alteração diretamente proporcional nos preços do fator de produção em estudo, na ordem de 3,77\%.

A elasticidade média da taxa de inflação com relação ao preço da terra de pastagem foi de 0,135 , ou seja, a elevação ou a queda de $10 \%$ na taxa de inflação fez com que os preços da terra de cultura variassem $1,35 \%$, no mesmo sentido dessa taxa.

O volume de subsídio concedido através do crédito rural foi a quarta variável que exerceu maior influência sobre os preços da terra para pastagem, segundo os resultados da pesquisa. A elevação de $10 \%$ do volume de subsídio concedido ocasionou o aumento de $0,51 \%$, em média, dos preços de venda do fator produtivo em questão.

A variável que menos influenciou a variação dos preços da terra de pastagem foi o hiato do produto, além de ter mantido uma relação inversa com a variável em questão. O aumento de $10 \%$ no hiato do produto provocou uma queda de, em média, $0,03 \%$ nos preços da terra de cultura. Vale relembrar que, pela definição do hiato do produto, o aumento deste hiato corresponde à queda do PIB efetivo, ou seja, ao desaquecimento da economia. 
A Tabela 10 traz uma comparação entre os resultados obtidos das regressões dos preços de venda da terra de pastagem, sendo explicadas pelo poder de compra do agricultor, pela taxa de juro real, pelo hiato do produto e pela taxa de inflação.

Tabela 10. Influência do poder de compra do agricultor, da taxa de juro real, do hiato do produto e da taxa de juro real sobre os preços de venda da terra de pastagem.

\begin{tabular}{cc}
\hline \multirow{2}{*}{ Análise de Regressão } & Preço da terra de pastagem \\
\cline { 2 - 2 } & $\mathrm{F}=6,36^{*}$ \\
$\mathrm{R}^{2}=0,52$ \\
\hline Variáveis & Coeficientes \\
\hline Constante & $926,00(0,58)$ \\
PC & $28,32^{* * * *}(1,75)$ \\
TJ & $30,77^{* * *}(1,85)$ \\
HIATO & $4.226,65^{*}(2,96)$ \\
LTINF & $999,46^{*}(2,91)$ \\
\hline
\end{tabular}

Fonte: Resultados da pesquisa.

Notas: Os valores da estatística t encontram-se entre parênteses;

*significativo a $1 \%$;

*** significativo a $5 \%$;

${ }^{* * *}$ significativo a $10 \%$.

$\mathrm{O}$ resultado do teste $\mathrm{F}$ indicou que o modelo é significativo a $1 \%$ e os parâmetros são significativos a pelo menos, 10\%. O coeficiente de determinação obtido indicou que $52 \%$ da variação no preço da terra para pastagem foram explicados pela variação conjunta do poder de compra do agricultor, da taxa de juro real, do hiato do produto e da taxa de inflação. Nota-se que este valor é bastante inferior àqueles obtidos nas regressões anteriores.

As Tabelas com os valores de $d$ (Durbin-Watson) e $\chi^{2}$ (teste de heterocedasticia de White) calculados, assim como a matriz de correlação simples das variáveis explicativas encontram-se nos Anexos $\mathrm{N}$ e O, respectivamente.

Não se observou auto-correlação positiva nos resíduos. Entretanto, o valor de $d$ calculado enquadra-se na área de indecisão, considerando-se 5\% de significância. Com relação à variância dos termos de erro, não se rejeitou a hipótese de homocedasticidade em ambas as regressões. 
As variáveis explicativas especificadas não apresentam relação linear, conforme a matriz de correlação simples. O mais alto coeficiente de correlação encontrado foi entre as variáveis hiato do produto e logaritmo da taxa de inflação $(r=0,42)$.

As elasticidades médias calculadas para interpretação das relações entre as variáveis explicativas e dependentes encontram-se na Tabela 11.

Tabela 11. Elasticidades médias das variáveis explicativas em relação aos preços da venda de terra de cultura e de pastagem.

\begin{tabular}{cc}
\hline Variáveis & Preço da terra de pastagem \\
\hline PC & 0,4459 \\
TJ & 0,0207 \\
HIATO & 0,0044 \\
LTINF & 0,1992 \\
\hline
\end{tabular}

Fonte: Resultados da pesquisa.

A variável que apresentou a maior elasticidade com relação aos preços do fator em questão foi o poder de compra do agricultor. A variação de $10 \%$ nesta variável alterou, em média e em mesmo sentido, 4,46\% os preços de venda da terra para pastagem.

Em seguida, a variação de $10 \%$ da taxa de inflação contribuiu positivamente com a alteração dos preços deste fator de produção, variando os preços da terra para pastagem, em média, $0,20 \%$.

A taxa de juro apresentou o comportamento esperado. A variação de $10 \%$ na taxa de juro alterou os preços de venda da terra para pastagem em 0,21\%, em sentido contrário ao da variação desta taxa. Isso significa que a queda/aumento da taxa de juro real elevou/aumentou o preço de venda da terra de pastagem em $0,21 \%$.

O último componente é o hiato do produto que, assim como nas regressões anteriores, exerceu menor influência na determinação dos preços de terra de pastagem, além de ter oscilado em sentido contrário ao dos preços da terra. A variação de $10 \%$ do hiato do produto alterou, em média, $0,04 \%$ os preços de venda de terra para pastagem, segundo a equação estimada. 
Analisando-se os resultados obtidos das sete regressões estimadas neste item, observam-se alguns padrões. Primeiramente, há grande sensibilidade do preço da terra com relação à rentabilidade da agricultura na determinação dos preços de venda da terra (tanto de altura como de pastagem), em detrimento de uma menor sensibilidade da taxa de inflação, da infra-estrutura, do volume de subsídio concedido através do crédito, da taxa de juro real e do hiato do produto. Pode-se inferir também que o poder de compra do agricultor mostrou ser mais relevante na determinação dos preços de venda da terra de lavoura que de pastagem, considerando-se as quatro primeiras regressões.

Relatam-se, a seguir, algumas colocações com relação aos determinantes dos preços de venda de terras para culturas e para pastagem.

Primeiramente, cabe mencionar que todos os modelos apresentados foram significativos a 1\%. Entretanto, os modelos que obtiveram maior coeficiente de determinação foram aqueles cujas variáveis explicativas são: índice de preços recebidos pelos produtores, índice de preços pagos pelos produtores (ambos defasados em um período), taxa de inflação, extensão da malha rodoviária do estado de São Paulo, hiato do produto e volume de subsídio concedido através do crédito rural (somente no caso da regressão para preço de terra de pastagem).

Quanto às variáveis selecionadas para representar a renda agrícola, destaca-se que o índice de paridade (IP) não foi adequado em nenhuma das regressões. Desta maneira, os índices de preços recebidos e de preços pagos pelos agricultores, defasados em um período (IPR e IPP) e o poder de compra do agricultor (PC) foram as variáveis que melhor representaram a renda agrícola nas análises em questão. Vale ressaltar que os dois primeiros índices compuseram regressões mais bem ajustadas que o poder de compra. Entretanto, somente na regressão em que o poder de compra representou a renda agrícola é que a taxa de juro foi significativa (somente no caso do preço de venda 
de terra para pastagem). Este fato se deve à possível existência de colinearidade entre as variáveis: índice de preços recebidos pelos produtores (IPR) e taxa de juro real (TJ) ${ }^{21}$.

Uma última colocação pode ser feita com relação aos determinantes dos preços de venda da terra para pastagem e de cultura de primeira. Em todas as regressões, a variável dependente em questão foi mais sensível às alterações dos determinantes relacionados diretamente com o setor agrícola, em detrimento dos determinantes indiretamente ligados a esse setor, como taxa de inflação e hiato do produto.

\subsection{Resultados obtidos das regressões para os valores de arrendamento de terras para culturas e de aluguel de pasto para animais}

São apresentados, inicialmente, os resultados obtidos pelas regressões estimadas para o valor do arrendamento para culturas.

A Tabela 12 apresenta os resultados da regressão, que tem como variáveis explicativas: índice de preços recebidos pelos produtores, índice de preços pagos pelos produtores, taxa de inflação e hiato do produto. A variável a ser explicada é o valor do arrendamento para culturas.

${ }^{21}$ O coeficiente de correlação simples entre IPR( 1) e TJ é igual a 0,63 . Embora este valor não seja um claro indício da presença de multicolinearidade entre as variáveis, a presença de IPR( 1), nas regressões estimadas, alterou o sinal esperado do coeficiente da variável TJ. 
Tabela 12. Influência do índice de preços recebidos pelos produtores, índice de preços pagos pelos produtores, taxa de inflação e hiato do produto sobre o valor do arrendamento para culturas.

\begin{tabular}{cc}
\hline \multirow{2}{*}{ Análise de Regressão Linear Múltipla } & Valor do arrendamento para culturas \\
\cline { 2 - 2 } & $\mathrm{F}=38,81^{*}$ \\
\hline Variáveis & Coeficientes \\
\hline Constante & $27,44(0,91)$ \\
IPR & $1,85^{*}(6,62)$ \\
IPP & $0,88^{* * *}(2,58)$ \\
LTINF & $19,79^{* * *}(2,23)$ \\
HIATO & $131,28^{*}(3,68)$ \\
\hline
\end{tabular}

Fonte: Resultados da pesquisa.

Notas: Os valores da estatística t encontram-se entre parênteses;

*significativo a $1 \%$;

** significativo a 5\%;

*** significativo a $10 \%$.

Os resultados obtidos dos testes $\mathrm{F}$ e $\mathrm{t}$ mostraram que tanto o modelo como os parâmetros são significativos a, pelo menos, 5\%. O coeficiente de determinação obtido indica que a equação foi bem ajustada.

As Tabelas com os valores de $d$ (Durbin-Watson) e $\chi^{2}$ (teste de heterocedasticia de White) calculados, assim como a matriz de correlação simples das variáveis explicativas encontram-se nos Anexos P e Q, respectivamente.

O resultado do teste $d$ de Durbin-Watson enquadrou-se na área inconclusiva, porém, próximo à área de não rejeição da hipótese de ausência de auto-correlação dos resíduos. Quanto à variância dos termos de erro, não se rejeitou a hipótese de homocedasticia, considerando-se o nível de significância igual a 5\%. O maior coeficiente de correlação simples encontrado entre as variáveis explicativas foi de 0,57, entre IPR e IPP. Contudo, esse valor não representa um problema de multicolinearidade.

A Tabela 13 apresenta as elasticidades dos índices de preços ecebidos pelos produtores, preços pagos pelos produtores, da taxa de inflação e do hiato do produto, com relação ao valor do arrendamento para culturas. 
Tabela 13. Elasticidades médias das variáveis explicativas em relação ao valor de arrendamento para culturas.

\begin{tabular}{cc}
\hline Variáveis & Valor do arrendamento para culturas \\
\hline IPR & 0,620 \\
IPP & 0,351 \\
LTINF & 0,068 \\
HIATO & 0,003 \\
\hline
\end{tabular}

Fonte: Resultados da pesquisa.

As variáveis que mais sensibilizam o valor do arrendamento para culturas são, conforme a regressão estimada, aqueles intrínsecos à atividade agrícola, que são: índice de preços recebidos pelos produtores e índice de preços pagos pelos produtores. A variação de $10 \%$ no índice de preços recebidos pelos agricultores alterou o valor do arrendamento para culturas, em média e em mesmo sentido, 6,20\%. Já a variação do índice de preços pagos alterou o valor do arrendamento para culturas, positivamente e em média, 3,5\%. Todavia, é preciso ter cautela quanto à análise dessa relação, dado que, conforme mencionado anteriormente, esperava-se que houvesse relação negativa entre o índice de preços pagos e valor do arrendamento para culturas.

Para a interpretação da relação observada entre índice de preços pagos e valor do arrendamento para culturas utiliza-se a mesma explanação dada anteriormente para a regressão dos preços de venda da terra de cultura de primeira e de terra para pastagem, sobre a composição deste índice, com a substituição entre fertilizantes, defensivos e terra, e o fato do arrendamento compor parte do índice de preços pagos.

A variação de $10 \%$ na taxa de inflação alterou o valor do arrendamento para culturas, em média, $0,68 \%$.

Com relação ao nível de atividade econômica, um aumento de $10 \%$ do hiato do produto (recordando que a média dessa variável é negativa) e, portanto, uma redução no nível de atividade (ou aumento do produto potencial), levou à queda de 0,03\%, em média, do valor do arrendamento da terra de cultura. Nota-se, portanto, a existência de relação inversa entre hiato do produto e valor do arrendamento para culturas; porém, relação direta entre esta última variável e nível de atividade econômica. 
O valor do arrendamento para culturas mostrou-se mais sensível aos índices de preços recebidos e de preços pagos que às variáveis selecionadas para representar o ambiente macroeconômico, que foram: taxa de inflação e hiato do produto.

A Tabela 14 apresenta os resultados da regressão que tem como variáveis explicativas: índice de preços recebidos pelos produtores, índice de preços pagos pelos produtores, variável binária (assumindo valor 1, de 1973 a 1994) e hiato do produto . A variável dependente é o arrendamento para culturas.

Tabela 14. Influência do índice de preços recebidos pelos produtores, do índice de preços pagos pelos produtores, da variável binária (assumindo valor 1, de 1973 a 1994) e do hiato do produto sobre o valor do arrendamento para culturas.

\begin{tabular}{cc}
\hline & Valor do arrendamento para culturas \\
\cline { 2 - 2 } Análise de Regressão Linear Múltipla & $\mathrm{F}=47,20^{*}$ \\
& $\mathrm{R}^{2}=0,87$ \\
\hline Variáveis & Coeficientes \\
\hline Constante & $32,76(1,08)$ \\
IPR & $1,45^{*}(5,67)$ \\
IPP & $0,71^{* *}(2,24)$ \\
BIN & $51,75^{*}(3,32)$ \\
HIATO & $119,86^{*}(3,84)$ \\
\hline
\end{tabular}

Fonte: Resultados da pesquisa.

Notas: Os valores da estatística t encontram-se entre parênteses;

*significativo a $1 \%$;

${ }^{* * *}$ significativo a $5 \%$;

**** significativo a $10 \%$.

A regressão estimada mostrou-se altamente significativa (1\%), conforme o resultado obtido no teste $\mathrm{F}$. Os coeficientes das variáveis explicativas também foram significativos a, pelo menos, 5\%. O coeficiente de determinação indicou que a regressão foi bem ajustada. Em comparação com o resultado da regressão anterior, ao substituir-se a taxa de inflação pela variável binária (o coeficiente de correlação simples entre essas variáveis indica que elas são colineares) ${ }^{22}$, o modelo obtido apresentou melhor ajuste.

${ }^{22}$ O coeficiente de correlação simples entre LTINF e BIN é igual a, aproximadamente, 0,72. 
As Tabelas com os valores de $d$ (Durbin-Watson) e $\chi^{2}$ (teste de heterocedasticia de White) calculados, assim como a matriz de correlação simples das variáveis explicativas encontram-se nos Anexos R e S, respectivamente.

Quanto à variância dos termos de erro, não se rejeitou a hipótese de homocedasticia, considerando o nível de significância de 5\%. O resultado do teste $d$ de Durbin-Watson, diferentemente dos casos anteriores, não permitiu a rejeição da hipótese nula. Assim, considerando-se o nível de significância de 5\%, não se pôde rejeitar a hipótese de ausência de auto-correlação, seja ela positiva ou negativa. $O$ maior coeficiente de correlação simples encontrado entre as variáveis explicativas foi de 0,64 , entre IPP e BIN. Entretanto, este resultado não representa um problema de multicolinearidade.

A Tabela 15 apresenta as elasticidades do índice de preços recebidos, do índice de preços pagos e do hiato do produto, em relação ao valor do arrendamento para culturas.

Tabela 15. Elasticidades médias das variáveis explicativas em relação ao valor de arrendamento para culturas.

\begin{tabular}{cc}
\hline Variáveis & Valor do arrendamento para culturas \\
\hline IPR & 0,4859 \\
IPP & 0,2850 \\
BIN & $0,2431^{*}$ \\
HIATO & 0,0032 \\
\hline
\end{tabular}

Fonte: Resultados da pesquisa.

*Esse resultado corresponde à variação relativa do valor do arrendamento para culturas quando a binária passa de 0 a 1.

Os resultados obtidos da regressão em análise são próximos daqueles descritos na regressão anterior, com exceção da variável taxa de inflação, que foi substituída pela binária.

A variação de $10 \%$ no índice de preços recebidos pelos agricultores altera o valor do arrendamento para culturas, em média, 4,86\%. Uma variação de $10 \%$ mo índice de preços pagos alterou o valor do arrendamento, em média e no mesmo sentido, 2,85\%. 
A análise do resultado da variação do valor do arrendamento e deste último determinante em mesmo sentido, segue o mesmo raciocínio descrito nas análises anteriores.

A variável binária indicou que os preços de arrendamento para cultura elevaram-se, em média, 24,31\% no período de 1973-94, com relação aos anos de 196972 e 1995-01.

Com relação ao nível de atividade econômica, um aumento de $10 \%$ no hiato do produto e, portanto, uma redução no nível de atividade, levou à queda de $0,03 \%$, em média, do valor do arrendamento da terra de cultura.

Observou-se, novamente, que o valor do arrendamento para culturas apresentou-se mais elástico às variáveis ligadas diretamente ao setor agrícola (IPR e IPP) que àquela indiretamente relacionada a este setor (HIATO).

A Tabela 16 apresenta a regressão que explica o valor do arrendamento para culturas através das variáveis: índice de paridade, taxa de inflação, hiato do produto e taxa de juro.

Tabela 16. Influência do índice de paridade, da taxa de inflação, do hiato do produto e da taxa de juro sobre o valor do arrendamento para culturas.

\begin{tabular}{cc}
\hline & Valor do arrendamento para culturas \\
\cline { 2 - 2 } Análise de Regressão Linear Múltipla & $\mathrm{F}=7,54^{*}$ \\
& $\mathrm{R}^{2}=0,57$ \\
\hline Variáveis & Coeficientes \\
\hline Constante & $62,81(0,84)$ \\
IP & $2,06932^{*}(3,10)$ \\
LTINF & $34,25850^{* * *}(2,10)$ \\
HIATO & $124,04720^{* * *}(1,91)$ \\
TJ & $1,63472^{* * *}(2,04)$ \\
\hline
\end{tabular}

Fonte: Resultados da pesquisa.

Notas: Os valores da estatística t encontram-se entre parênteses;

*significativo a $1 \%$;

${ }^{* *}$ significativo a $5 \%$;

${ }^{* * *}$ significativo a $10 \%$. 
Os resultados estatísticos obtidos pela regressão em análise não foram tão satisfatórios quanto os resultados das duas regressões anteriores. Não obstante, optou-se por apresentar estas estimativas, uma vez que este foi o único modelo cujo valor do arrendamento tem como uma das variáveis explicativas a taxa de juro, em nível de significância aceitável. Desta maneira, pode-se observar o efeito desta variável sobre o valor do arrendamento para culturas.

Os resultados dos testes $\mathrm{F}$ e $\mathrm{t}$ foram significativos a $1 \%$ e a, pelo menos, $10 \%$, respectivamente. $\mathrm{O}$ coeficiente de determinação indicou que a regressão não foi tão bem ajustada quanto as duas anteriores.

As Tabelas com os valores de $d$ (Durbin-Watson) e $\chi^{2}$ (teste de heterocedasticia de White) calculados, assim como a matriz de correlação simples das variáveis explicativas encontram-se nos Anexos T e U, respectivamente.

Quanto à variância dos termos de erro, não se rejeitou a hipótese nula de homocedasticidade. Já o resultado do teste $d$ de Durbin-Watson enquadrou-se na área inconclusiva e próximo à área de rejeição da hipótese nula de ausência de autocorrelação positiva, considerando-se o nível de significância de 5\%. O maior coeficiente de correlação simples encontrado entre as variáveis explicativas foi de 0,42 , entre as variáveis hiato do produto e logaritmo da taxa de inflação.

A Tabela 17 traz as elasticidades do índice de paridade, da taxa de inflação, do hiato do produto e da taxa de juro, em relação ao valor do arrendamento para culturas.

Tabela 17. Elasticidades médias das variáveis explicativas em relação ao valor de arrendamento para culturas.

\begin{tabular}{cc}
\hline Variáveis & Valor do arrendamento para culturas \\
\hline IP & 0,577 \\
LTINF & 0,116 \\
HIATO & 0,002 \\
TJ & 0,019 \\
\hline
\end{tabular}

Fonte: Resultados da pesquisa. 
Nota-se que uma variação de $10 \%$ nos termos de troca alterou o valor do arrendamento para culturas, em média, 5,77\%. Com relação à taxa de inflação, o aumento de $10 \%$ dessa taxa elevou os preços de arrendamento para cultura, em média, $1,16 \%$. O aumento de $10 \%$ no hato do produto levou à queda de $0,02 \%$, em média, m valor do arrendamento da terra de cultura.

A relação obtida entre taxa de juro e preço do arrendamento para culturas foi negativa e condizente com o esperado. A elevação de $10 \%$ na taxa de juro real ocasionou a redução de 0,19\% no valor do arrendamento para culturas. Essa relação pode ser interpretada como o custo de oportunidade do investimento. A elevação da taxa de juro aumenta o custo de oportunidade do investimento em arrendamento para culturas, levando à menor demanda por essas terras e, conseqüentemente, menor preço. $\mathrm{O}$ mesmo raciocínio procede se a taxa de juro diminuir. A taxa de juro real em queda leva à maior rentabilidade dos investimentos, ceteris paribus. Diminuindo a taxa de juro real, a demanda por terras aumenta (no caso, arrendamento de terras para culturas) e seu preço, conseqüentemente, eleva-se.

Relatam-se, a seguir, algumas colocações com relação aos determinantes dos preços de arrendamento para culturas.

Primeiramente, cabe mencionar que os três modelos apresentados foram significativos a $1 \%$. Entretanto, os dois modelos que obtiveram maior coeficiente de determinação foram aqueles cujas variáveis explicativas são: 1) índice de preços recebidos pelos produtores, índice de preços pagos pelos produtores, taxa de inflação e hiato do produto; 2) índice de preços recebidos pelos produtores, índice de preços pagos pelos produtores, variável binária e hiato do produto.

Com relação aos determinantes dos preços do arrendamento de culturas observou-se, primeiramente, que o volume de subsídio concedido através do crédito rural não se mostrou significativo em nenhuma das regressões, fato que o excluiu dessa análise. 
Quanto às variáveis selecionadas para representar a renda agrícola, destaca-se que o poder de compra (PC) não foi significativo em nenhuma das regressões. Desta maneira, os índices de preços recebidos e de preços pagos pelos agricultores (IPR e IPP) e o índice de paridade (IP) foram as variáveis que melhor representaram a renda agrícola na análise em questão. Vale ressaltar que os dois primeiros índices compuseram regressões mais bem ajustadas que o índice de paridade. Entretanto, somente na regressão em que o índice de paridade representou a renda agrícola é que a taxa de juro foi significativa. Este fato se deve à possível existência de colinearidade entre as variáveis: índice de preços recebidos pelos produtores (IPR) e taxa de juro real (TJ) ${ }^{23}$.

Uma última colocação pode ser feita com relação aos determinantes do arrendamento de terras para cultura. Em todas as regressões, a variável dependente em questão foi mais sensível às alterações dos determinantes relacionados diretamente com o setor agrícola, em detrimento dos determinantes indiretamente ligados a esse setor, como taxa de inflação e hiato do produto.

A seguir segue a análise dos determinantes do aluguel de pasto para animais.

A Tabela 18 apresenta os resultados obtidos pela regressão do índice de paridade e da variável binária, em relação ao valor do aluguel de pasto para animais.

${ }^{23} \mathrm{O}$ coeficiente de correlação simples entre IPR e TJ é igual a $\quad 0,55$. Embora este valor não seja um claro indício da presença de multicolinearidade entre as variáveis, a presença de IPR, nas regressões estimadas, alterou o sinal do coeficiente da variável TJ. 
Tabela 18. Influência do índice de paridade e da variável binária (assumindo valor 1, de 1973-94) sobre o valor do aluguel de pasto para animais.

\begin{tabular}{cc}
\hline & Aluguel de pasto para animais \\
\cline { 2 - 2 } Análise de Regressão Linear Múltipla & $\mathrm{F}=28,98^{*}$ \\
& $\mathrm{R}^{2}=0,66$ \\
\hline Variáveis & Coeficientes \\
\hline Constante & $8,74(0,33)$ \\
IP & $1,22^{*}(4,10)$ \\
BIN & $68,78^{*}(6,01)$ \\
\hline
\end{tabular}

Fonte: Resultados da pesquisa.

Notas: Os valores da estatística t encontram-se entre parênteses;

*significativo a $1 \%$;

${ }^{* *}$ significativo a $5 \%$;

${ }^{* * * *}$ significativo a $10 \%$.

Os resultados dos testes $\mathrm{F}$ e $\mathrm{t}$ mostraram que o modelo e os parâmetros são altamente significativos (1\%). O coeficiente de determinação obtido indicou que o índice de paridade e a variável binária explicaram $66 \%$ da variação mo valor do aluguel de pasto.

As Tabelas com os valores de $d$ (Durbin-Watson) e $\chi^{2}$ (teste de heterocedasticia de White) calculados, assim como a matriz de correlação simples das variáveis explicativas encontram-se nos Anexos V e W, respectivamente.

Conforme mostraram os resultados dos testes de heterocedasticia e de autocorrelação, ño foram rejeitadas as hipóteses de termos de erro homocedásticos e de ausência de auto-correlação dos resíduos. Analisando-se a matriz de correlação simples, nota-se que não há colinearidade entre as variáveis independentes.

Apresenta-se, na Tabela 19, a elasticidade média do índice de paridade em relação ao valor do aluguel de pasto para animais. 
Tabela 19. Elasticidades médias das variáveis explicativas em relação ao valor do aluguel de pasto para animais.

\begin{tabular}{cc}
\hline Variáveis & Aluguel de pasto para animais \\
\hline Constante & - \\
IP & 0,6530 \\
BIN & $0,6310^{*}$ \\
\hline
\end{tabular}

Fonte: Resultados da pesquisa.

*Esse resultado corresponde à variação relativa do valor do arrendamento para culturas quando a binária passa de 0 a 1 .

A alteração no índice de paridade afeta sensivelmente o valor do aluguel de pasto para animais: uma variação de $10 \%$ neste índice refletiu em variação de $6,53 \%$ do valor deste aluguel.

A variável binária utilizada para verificar se houve mudança no nível do valor de arrendamento de pasto, no período de 1973 a 1994, foi significativa. Este resultado indica que o intercepto deslocou-se 63,10\% no período em que a variável assumiu valor 1, em relação aos períodos 1969-72 e 1995-01.

A seguir, estão apresentados na Tabela 20 os resultados da regressão linear múltipla do valor do aluguel de pasto em função do índice de paridade, da taxa de inflação e do hiato do produto. 
Tabela 20. Influência do índice de paridade, da taxa de inflação e do hiato do produto sobre o valor do aluguel de pasto para animais.

\begin{tabular}{cc}
\hline & Aluguel de pasto para animais \\
\cline { 2 - 2 } Análise de Regressão Linear Múltipla & $\mathrm{F}=8,85^{*}$ \\
& $\mathrm{R}^{2}=0,48$ \\
\hline Variáveis & Coeficientes \\
\hline Constante & $57,04(1,29)$ \\
IP & $1,80^{*}(4,43)$ \\
LTINF & $34,04^{*}(3,52)$ \\
HIATO & $71,71^{* *}(1,78)$ \\
\hline
\end{tabular}

Fonte: Resultados da pesquisa.

Notas: Os valores da estatística t encontram-se entre parênteses;

"significativo a $1 \%$;

${ }^{* *}$ significativo a $5 \%$;

**** significativo a $10 \%$.

O modelo estimado foi significativo a $1 \%$ e os parâmetros a $1 \%, 1 \%$ e $5 \%$, respectivamente (desconsiderando-se a constante). $\mathrm{O}$ coeficiente de determinação indicou que $48 \%$ da variação no aluguel de pasto foram explicados pelo índice de paridade, pela taxa de inflação e pelo hiato do produto. Comparando-se à regressão anterior, o resultado deste coeficiente mostrou-se menos interessante.

As Tabelas com os valores de $d$ (Durbin-Watson) e $\chi^{2}$ (teste de heterocedasticia de White) calculados, assim como a matriz de correlação simples das variáveis explicativas encontram-se nos Anexos X e Y, respectivamente.

Quanto à variância dos termos de erro assim como nas regressões anteriores, não se rejeitou a hipótese de homocedasticidade. O resultado do teste $d$ de DurbinWatson enquadrou-se na área de indefinição, ou seja, nada se pode concluir a respeito da existência de auto-correlação, considerando-se o nível de 5\% de significância. O mais alto coeficiente de correlação simples encontrado entre as variáveis explicativas foi de 0,39, entre o logaritmo da taxa de inflação e o hiato do produto.

A Tabela 21 apresenta as elasticidades do índice de paridade, da taxa de inflação e do hiato do produto, em relação ao valor do aluguel de pasto para animais. 
Tabela 21. Elasticidades médias das variáveis explicativas em relação ao valor de aluguel de pasto para animais.

\begin{tabular}{cc}
\hline Variáveis & Aluguel de pasto para animais \\
\hline IP & 0,962 \\
LTINF & 0,216 \\
HIATO & 0,004 \\
\hline
\end{tabular}

Fonte: Resultados da pesquisa.

A variação de $10 \%$ no índice de paridade alterou o valor do aluguel de pastos, em média e em mesmo sentido, 9,62\%.

Com relação às variáveis macroeconômicas, a taxa de inflação exerceu influência positiva sobre os preços do aluguel de pasto. A alteração de $10 \%$ desta variável variou os preços do aluguel de terra para pastagem, em média, 2,16\%. Quanto ao nível de atividade econômica, um aumento de $10 \%$ no hiato do produto (dado que o hiato é negativo) e, portanto, uma redução no nível de atividade, levou à queda de 0,04\%, em média, no valor do arrendamento da terra de cultura.

A Tabela 22 apresenta os resultados obtidos pela regressão do índice de paridade, do volume de subsídio creditício concedido e da taxa de inflação sobre o valor do aluguel de pasto para animais. 
Tabela 22. Influência do índice de paridade, do volume de subsídio concedido através do crédito rural e da taxa de inflação sobre o valor do aluguel de pasto para animais.

\begin{tabular}{cc}
\hline & Aluguel de pasto para animais \\
\cline { 2 - 2 } Análise de Regressão Linear Múltipla & $\mathrm{F}=11,50^{*}$ \\
& $\mathrm{R}^{2}=0,54$ \\
\hline Variáveis & Coeficientes \\
\hline Constante & $3,85(0,08)$ \\
IP & $1,20^{* *}(2,68)$ \\
VCRSUB & $0,01^{*}(2,78)$ \\
LTINF & $20,67^{* *}(2,31)$ \\
\hline
\end{tabular}

Fonte: Resultados da pesquisa.

Notas: Os valores da estatística t encontram-se entre parênteses;

*significativo a $1 \%$;

${ }^{* *}$ significativo a $5 \%$;

${ }^{* * *}$ significativo a $10 \%$.

O modelo estimado é altamente significativo, com parâmetros também significativos e coeficiente de determinação intermediário, porém, mais alto que o da regressão anterior.

As Tabelas com os valores de $d$ (Durbin-Watson) e $\chi^{2}$ (teste de heterocedasticia de White) calculados, assim como a matriz de correlação simples das variáveis explicativas encontram-se nos Anexos Ze AA, respectivamente.

Quanto aos termos de erro, não se rejeitou a hipótese de homocedasticia e o valor $d$ de Durbin-Watson encontra-se na área inconclusiva. Com relação às variáveis independentes, o maior coeficiente de correlação simples obtido foi entre volume de subsídio concedido através do crédito rural e índice de paridade $(0,47)$.

$\mathrm{Na}$ Tabela 23 encontram-se as elasticidades médias do índice de paridade, do volume de subsídio creditício concedido e da taxa de inflação, em relação ao valor do aluguel de pasto para animais. 
Tabela 23. Elasticidades médias das variáveis explicativas em relação ao valor do aluguel de pasto para animais.

\begin{tabular}{cc}
\hline Variáveis & Aluguel de pasto para animais \\
\hline IP & 0,641 \\
VCRSUB & 0,089 \\
LTINF & 0,131 \\
\hline
\end{tabular}

Fonte: Resultados da pesquisa.

Analisando-se as elasticidades da regressão em questão, nota-se que o índice de paridade, representando a renda do agricultor, dada uma variação idêntica em todas as variáveis explicativas, é o determinante que mais influencia o valor do aluguel de pasto para animais, assim como na regressão anterior.O aumento de $10 \%$ desse índice elevou, em média, $6,41 \%$ os preços do aluguel desta categoria de terra.

O volume de subsídio concedido através do crédito rural também teve influência na determinação do valor do aluguel de pasto, no período considerado. A variação de $10 \%$ no volume de subsídio concedido correspondeu à variação de $0,89 \%$ no valor do aluguel de pasto.

O valor do aluguel de pasto variou positivamente em relação à taxa de inflação. A alteração de $10 \%$ desta taxa variou $1,31 \%$ o preço do aluguel desta categoria.

A Tabela 24 apresenta os resultados obtidos da regressão estimada para aluguel de pasto, cujas variáveis explicativas são: índice de paridade, taxa de inflação e taxa de juro. 
Tabela 24. Influência do índice de paridade, da taxa de inflação e da taxa de juro sobre o valor do aluguel de pasto para animais.

\begin{tabular}{cc}
\hline & Aluguel de pasto para animais \\
\cline { 2 - 2 } Análise de Regressão Linear Múltipla & $\mathrm{F}=8,30^{*}$ \\
& $\mathrm{R}^{2}=0,51$ \\
\hline Variáveis & Coeficientes \\
\hline Constante & $12,17(0,25)$ \\
IP & $1,61^{* *}(3,61)$ \\
LTINF & $21,66^{* *}(2,20)$ \\
TJ & $0,86(1,68)$ \\
\hline
\end{tabular}

Fonte: Resultados da pesquisa.

Notas: Os valores da estatística t encontram-se entre parênteses;

"significativo a $1 \%$;

*** significativo a $5 \%$;

**** significativo a $10 \%$.

O modelo estimado é altamente significativo. Os parâmetros referentes às variáveis índice de paridade e taxa de inflação são significativos a $1 \%$ e a $5 \%$, respectivamente. O parâmetro da taxa de juro é significativo a 10,6\%. Embora este parâmetro esteja fora dos limites aceitáveis para rejeição da hipótese nula, optou-se por incluir esse modelo a fim de se analisar a relação existente entre taxa de juro e valor do aluguel de pasto para animais. O coeficiente de determinação indicou que $51 \%$ da variação do aluguel de pasto para animais foram explicados pelo índice de preços, taxa de inflação e taxa de juro.

As Tabelas com os valores de $d$ (Durbin-Watson) e $\chi^{2}$ (teste de heterocedasticia de White) calculados, assim como a matriz de correlação simples das variáveis explicativas encontram-se nos Anexos BB e CC, respectivamente.

Não se rejeitou a hipótese de termos de erro homocedástico. O valor $d$ de Durbin-Watson calculado encontra-se na área inconclusiva, porém, próximo ao valor crítico de não rejeição da hipótese de ausência de auto-correlação (a 5\%). Com relação à colinearidade entre as variáveis independentes, o maior valor observado foi entre taxa de inflação e índice de paridade ( 0,34$)$. 
$\mathrm{Na}$ Tabela 25 encontram-se as elasticidades médias das variáveis explicativas índice de paridade e taxa de inflação em relação ao valor do aluguel de pasto para animais.

Tabela 25. Elasticidades médias das variáveis explicativas em relação ao aluguel de pasto para animais.

\begin{tabular}{cc}
\hline Variáveis & Aluguel de pasto para animais \\
\hline IP & 0,826 \\
LTINF & 0,135 \\
TJ & 0,018 \\
\hline
\end{tabular}

Fonte: Resultados da pesquisa.

A variação de $10 \%$ no índice de paridade gerou a variação de $8,26 \%$, em média e em mesmo sentido, no valor do aluguel de pasto.

A variável taxa de inflação, assim como nas análises anteriores, alterou os preços de aluguel de terra para pastagem no mesmo sentido e, em média, 1,35\% (dada uma variação de $10 \%$ nessa taxa).

A taxa de juro, assim como na regressão para arrendamento de terras para culturas, apresentou relação inversa à da variável em estudo. A variação de $10 \%$ dessa taxa variou, em sentido contrário, $0,18 \%$ o valor do aluguel de pasto para animais.

Sintetizando os resultados obtidos para preço do aluguel de pasto, podem-se ressaltar algumas observações.

Primeiramente, a regressão que apresentou melhor ajuste foi aquela composta somente pelo índice de paridade e pela variável binária. Esta foi a regressão que apresentou o maior coeficiente de determinação. Todos os modelos apresentados foram significativos a $1 \%$.

Com relação às elasticidades, pode-se inferir que o índice de paridade mostrouse o principal determinante do preço do aluguel de pasto, assim como foi a única variável significativa dentre as representantes da renda agrícola adotadas no estudo. $\mathrm{O}$ 
volume de subsídio concedido através do crédito rural também foi significativo em uma das regressões e apresentou relação positiva com a variável dependente.

As variáveis de interesse macroeconômico (taxa de inflação, hiato do produto e taxa de juro) mostraram ter relação com o aluguel de pasto. As duas primeiras apresentaram relação direta (embora o nível de atividade tenha relação oposta) enquanto que a taxa de juro manteve uma relação inversa com o preço do aluguel de pastagem.

A variável binária indicou que houve, no período de 1973 a 1994, deslocamento do intercepto da regressão a um patamar 65,3\% mais alto que nos períodos de 1969-72 e 1995-01.

Comparando-se as regressões de determinação do valor do arrendamento para culturas com as regressões de determinação do preço do aluguel de pasto, podem-se realçar alguns pontos.

Primeiramente, as variáveis representativas da renda agrícola apresentaram as maiores elasticidades em relação às variáveis dependentes (tanto para culturas quanto para pasto). Os índices de preços recebidos e de preços pagos compuseram as regressões que foram mais bem ajustadas para o arrendamento para culturas. Já para aluguel de pastos, tais índices não foram significativos e o índice de paridade foi o determinante que representou a renda agrícola.

Quanto às variáveis macroeconômicas, todas exibiram comportamentos semelhantes em relação aos preços dos arrendamentos em questão. A taxa de inflação apresentou relação positiva enquanto que o hiato do produto e a taxa de juro mostraramse negativamente relacionados às variáveis em questão. Além disso, as variáveis macroeconômicas exerceram maior influência sobre os preços do aluguel de pasto para animais que sobre o valor do arrendamento para culturas, com exceção da taxa de juro real.

O volume de subsídio concedido através do crédito rural não foi significativo em nenhuma das regressões estimadas para arrendamento de terra para culturas. 
A variável binária apresentou resultados contundentes com as expectativas. Tal variável foi utilizada para se verificar se houve aumento significativo nos preços dos arrendamentos para culturas e para pasto, no período de 1973-94. Os resultados indicaram que o deslocamento do intercepto no período de 1973-94 foi maior nas regressões de aluguel de pastos que na de arrendamento para culturas.

Embora o preço do aluguel para pasto tenha exibido comportamento mais elástico com relação às variáveis explicativas selecionadas, algumas regressões estimadas para valor de arrendamento para culturas apresentaram maior coeficiente de determinação. Dessa afirmação, há a hipótese de que existam outros fatores, os quais não foram incluídos neste estudo, que complementem a explicação dos determinantes dos preços do aluguel de terras para pastagem, como por exemplo, o preço da arroba do boi.

Assim como se verificou nos resultados obtidos para os preços de venda da terra, os preços de arrendamento encontram-se fortemente associados à rentabilidade da atividade agrícola.

Com relação à análise de regressão, chega-se a algumas conclusões. Todos os modelos obtidos mostraram-se significativos a $1 \%$, com parâmetros significativos a, pelo menos, $10 \%$ (exceto para o parâmetro da taxa de juro real na regressão de aluguel de pasto). Os coeficientes de determinação obtidos apresentaram valores satisfatórios, indicando que as variações das variáveis dependentes foram bem explicadas pelas variações nas variáveis independentes.

Primeiramente, com relação à variância dos termos de erro, em nenhuma das regressões obtidas rejeitou-se a hipótese de homocedasticia, respeitando o nível de significância de 5\%. Quanto à auto-correlação dos resíduos, nenhuma das equações estimadas apresentou este problema. Exceto uma das regressões de valor do arrendamento para culturas, não se pôde confirmar a ausência de auto-correlação nas equações estimadas, uma vez que a maioria dos resultados do $d$ de Durbin-Watson encontraram-se na área de indefinição. 
O maior coeficiente de correlação encontrado entre as variáveis explicativas foi de 0,62 , indicando correlação positiva entre índice de preços recebidos defasado em um período e volume de subsídio concedido através do crédito rural. Entretanto, este valor não se constituiu em problema sério de multicolinearidade. Ressalta-se, todavia, que um alto coeficiente de correlação simples é condição suficiente mas não necessária para presença de multicolinearidade, tal como mencionado anteriormente. As matrizes de correlação simples, incluindo todas as variáveis explicativas deste estudo, encontram-se nos Anexos DD, EE e FF.

Quanto à análise das elasticidades pode-se concluir que os componentes que representam a renda ou a rentabilidade da agricultura foram os que obtiveram maior êxito na determinação tanto dos preços de venda como nos preços de arrendamento da terra de cultura e de pastagem, concordando com vários trabalhos, dentre eles os de Romeiro e Reydon (1994) e Dias, Vieira e Amaral (2001).

O volume de subsídio concedido através do crédito rural apresentou maior influência sobre os preços de venda da terra de pastagem que da terra de culturas. Além disso, essa variável foi um dos determinantes do aluguel de pasto. Dias, Vieira e Amaral (2001), embora tenham utilizado montante de crédito rural concedido por hectare, em vez do volume de subsídio, também obtiveram relação positiva entre a variável em questão e preço de venda da terra. Entretanto, a elasticidade do crédito rural com relação ao preço da terra, resultante da pesquisa desses autores, foi mais baixa que aquela obtida neste estudo. Uma possível justificativa para esta diferença pode estar justamente na construção da variável.

A taxa de juro influenciou negativamente os preços de venda da terra de pastagem e de arrendamento para culturas e pastagem. A taxa de inflação afetou positivamente os preços de venda das duas categorias de terra em estudo, assim como o valor do arrendamento para culturas e para pastagem, conforme observaram também Dias, Vieira e Amaral (2001). 
A variável utilizada como proxy da infra-estrutura (RODO) apresentou relação positiva com os preços de venda da terra de cultura e de pastagem. Entretanto, não foi significativa em nenhuma das regressões de arrendamento.

O hiato do produto é um componente que, além de variar em sentido oposto ao dos preços de venda e dos valores de arrendamento (tanto para culturas como para pastagem), mostrou-se significativo na determinação de todos estes preços. Vale ressaltar que, embora o comportamento do hiato varie em sentido oposto ao dos preços de venda de terras e do valor do arrendamento, o nível de atividade econômica afeta diretamente esses preços.

Através da variável binária, houve deslocamento significativo do intercepto dos preços de venda de terra e de arrendamento (para as duas categorias em estudo), no período de 1973-94.

Conclui-se, então, que os fatores ligados ao setor agrícola apresentaram maiores elasticidades na determinação dos preços de venda e de aluguel da terra, tanto para culturas como para pastagem, em detrimento de variáveis macroeconômicas associadas à especulação, como taxa de inflação e hiato do produto.

Pode-se ressaltar uma última observação, advinda do fato de os preços de venda de dois diferentes tipos de terra serem explicados, em alguns casos, pelos mesmos regressores e apresentarem coeficientes de determinação semelhantes. Estes preços apresentam comportamentos semelhantes no tempo, o que pode ser um indício de que existe um equilíbrio estável de longo prazo entre os fatores de diferentes categorias. Para confirmar tal hipótese, são apresentados, a seguir, os testes de co-integração entre os preços de venda de terra de diferentes categorias, dentro do estado de São Paulo e entre os preços de venda de terra de cultura e de pastagem em São Paulo, e de lavoura e pastagem em outros estados do Centro-Sul do país. 


\subsection{Resultados dos testes de raiz unitária}

Os testes de raiz unitária constituem-se na etapa prévia aos testes de cointegração, como descrito no capítulo anterior.

São descritos, a seguir, os valores calculados dos testes que compõem o teste de raiz unitária, de acordo com a metodologia proposta por Dickey e Fuller (1979) e Dickey e Fuller (1981).

A Tabela 26 apresenta os testes de raiz unitária de Dickey e Fuller (DF) e Dickey e Fuller Aumentado (ADF) para as séries de preços de venda de terra de diferentes categorias, no estado de São Paulo.

Tabela 26. Resultados dos testes de raiz unitária para as séries de preços das terras de cultura de primeira, de cultura de segunda, de pastagem, de reflorestamento e de campo, no estado de São Paulo (1969 - 2001).

\begin{tabular}{|c|c|c|c|c|c|c|c|c|c|c|}
\hline \multirow[t]{2}{*}{ Variáveis } & \multirow{2}{*}{$\begin{array}{l}\text { Valor } \\
\text { de } p-1\end{array}$} & \multicolumn{7}{|c|}{ Modelo 1} & \multirow{2}{*}{$\begin{array}{c}\text { Modelo2 }^{2} \\
\tau\end{array}$} & \multirow{2}{*}{$\begin{array}{l}\text { Ordem de } \\
\text { Integração }\end{array}$} \\
\hline & & $\tau_{\tau}$ & $\tau_{\beta \tau}$ & $\phi_{3}$ & $\tau_{\mu}$ & $\tau_{\alpha \mu}$ & $\phi_{1}$ & $\tau$ & & \\
\hline $\begin{array}{l}\text { Cultura de } \\
\text { primeira }\end{array}$ & 0 & $-2,46$ & $-1,33$ & 3,84 & $-2,40$ & 2,31 & 2,91 & $-0,64$ & $-5,05^{* *}$ & $\mathrm{I}(1)$ \\
\hline $\begin{array}{l}\text { Cultura de } \\
\text { Segunda }\end{array}$ & 0 & $-2,41$ & $-1,26$ & 3,66 & $-2,37$ & 2,28 & 2,84 & $-0,65$ & $-5,11^{* *}$ & $\mathrm{I}(1)$ \\
\hline Pastagem & 0 & $-2,33$ & $-1,22$ & 3,47 & $-2,32$ & 2,22 & 2,71 & $-0,66$ & $-4,99^{* *}$ & $\mathrm{I}(1)$ \\
\hline $\begin{array}{l}\text { Refloresta } \\
\text { mento }\end{array}$ & 0 & $-2,39$ & $-1,03$ & 3,55 & $-2,46$ & 2,34 & 3,05 & $-0,74$ & $-5,07^{* *}$ & $\mathrm{I}(1)$ \\
\hline Campos & 1 & $-2,71$ & $-0,97$ & 4,34 & $-2,78$ & $2,64^{* *}$ & 3,89 & $-0,81$ & $-5,08^{* *}$ & $\mathrm{I}(1)$ \\
\hline
\end{tabular}

Fonte: Resultados da pesquisa.

** Significativo a 5\% considerando os valores críticos em Fuller (1976) e Dickey \& Fuller (1981) e para amostra com 25 observações.

Modelo $1 \Rightarrow \Delta x_{t}=\alpha+\beta t+\gamma x_{t-1}+\sum_{i=1}^{p-1} \lambda_{i} \Delta x_{t-i}+\varepsilon_{t}$, nas versões com constante e tendência, sem tendência e sem tendência e constante.

Modelo $2 \Rightarrow \Delta \Delta x_{t}=\gamma \Delta x_{t-1}+\sum_{i=1}^{p-2} \lambda_{\imath} \Delta \Delta x_{t-i}+\varepsilon_{t}$, definido após constatar-se a não existência de termos deterministas.

Nota: não houve presença de autocorrelação serial, conforme o teste $Q$ de Ljung Box. 
Os resultados dos testes de DF e ADF mostraram que todas as séries são I(1), ou seja, que necessitam de 1 diferença a fim de que se tornem estacionárias. Para as séries de preços de terras de cultura de primeira, de cultura de segunda, de pastagem e de reflorestamento, utilizou-se o teste de Dickey e Fuller. Para a série de preço de terra para campos, utilizou-se o teste de Dickey e Fuller Aumentado, uma vez que foram necessárias duas defasagens para se eliminar o problema de auto-correlação dos resíduos.

Uma segunda colocação sobre os preços de terra para campos refere-se à estatística $\tau_{\alpha \mu}$. A hipótese de que a constante, segundo os valores críticos deste teste, seja igual a zero, foi rejeitada. Entretanto, segundo a estatística $\phi_{1}$, o modelo não foi significativo, ou seja, não se pôde rejeitar a hipótese conjunta de que $\tau_{\mu}$ e $\tau_{\alpha \mu}$ sejam iguais a zero. Desta maneira, seguiram-se os procedimentos e concluiu-se que a série tem uma raiz unitária.

A Tabela 27 apresenta os testes de raiz unitária de Dickey e Fuller (DF) e Dickey e Fuller Aumentado (ADF) para as séries de preços de terra de lavoura e pastagem, em diversos estados do Centro-Sul do país. 
Tabela 27. Resultados dos testes de raiz unitária para as séries de preços das terras de lavoura (L) e de pastagem (P) nos estados de Goiás, Mato Grosso, Rio de Janeiro, Espírito Santo, Rio de Janeiro, Minas Gerais, Paraná, Santa Catarina e Rio Grande do Sul (1969 - 2001).

\begin{tabular}{|c|c|c|c|c|c|c|c|c|c|c|}
\hline \multirow[t]{2}{*}{ Variáveis } & \multirow{2}{*}{$\begin{array}{l}\text { Valor } \\
\text { de } p-1\end{array}$} & \multicolumn{7}{|c|}{ Modelo $1^{1}$} & \multirow{2}{*}{$\begin{array}{c}\begin{array}{c}\text { Modelo } \\
2^{2}\end{array} \\
\tau \\
\end{array}$} & \multirow{2}{*}{$\begin{array}{l}\text { Ordem de } \\
\text { Integração }\end{array}$} \\
\hline & & $\tau_{\tau}$ & $\tau_{\beta \tau}$ & $\phi_{3}$ & $\tau_{\mu}$ & $\tau_{\alpha \mu}$ & $\phi_{1}$ & $\tau$ & & \\
\hline LGO & 2 & $-2,45$ & $-0,07$ & 3,48 & $-2,69$ & $2,63^{* * *}$ & 3,66 & $-0,58$ & $-6,07^{* *}$ & $\mathrm{I}(1)$ \\
\hline PGO & 2 & $-2,76$ & $-0,25$ & 4,36 & $-3,00$ & $2,89^{* *}$ & 4,51 & $-0,70$ & $-5,77^{* *}$ & $\mathrm{I}(1)$ \\
\hline LMT & 1 & $-3,32$ & $-1,23$ & 5,68 & $-3,10$ & $2,92^{* *}$ & 4,84 & $-0,95$ & $-7,49^{* *}$ & $\mathrm{I}(1)$ \\
\hline PMT & 0 & $-3,42$ & $-1,71$ & 6,10 & $-2,95$ & $2,73^{* *}$ & 4,35 & $-1,01$ & $-5,89^{* *}$ & $\mathrm{I}(1)$ \\
\hline LRJ & 2 & $-1,76$ & $-1,36$ & 2,71 & $-1,86$ & 1,78 & 1,74 & $-0,55$ & $-6,36^{* *}$ & $\mathrm{I}(1)$ \\
\hline PRJ & 0 & $-2,92$ & $-0,69$ & 4,54 & $-2,96$ & 2,61 & 4,38 & $-1,28$ & $-6,83^{* *}$ & $\mathrm{I}(1)$ \\
\hline LES & 2 & $-2,32$ & $-0,63$ & 3,20 & $-2,48$ & 2,28 & 3,08 & $-0,90$ & $-6,25^{* *}$ & $\mathrm{I}(1)$ \\
\hline PES & 2 & $-2,53$ & $-0,83$ & 3,77 & $-2,63$ & 2,44 & 3,47 & $-0,91$ & $-6,25^{* *}$ & $\mathrm{I}(1)$ \\
\hline LMG & 2 & $-2,32$ & $-0,94$ & 3,32 & $-2,40$ & 2,25 & 2,89 & $-0,78$ & $-6,36^{* *}$ & $\mathrm{I}(1)$ \\
\hline PMG & 2 & $-2,38$ & $-1,28$ & 3,56 & $-2,31$ & 2,15 & 2,67 & $-0,79$ & $-6,17^{* *}$ & $\mathrm{I}(1)$ \\
\hline LPR & 0 & $-2,87$ & $-0,22$ & 4,43 & $-3,02$ & $2,73^{* *}$ & 4,56 & $-1,17$ & $-7,40^{* *}$ & $\mathrm{I}(1)$ \\
\hline PPR & 2 & $-2,91$ & $-1,53$ & 5,03 & $-2,71$ & $2,64^{* *}$ & 3,68 & $-0,54$ & $-5,51^{* *}$ & $\mathrm{I}(1)$ \\
\hline LSC & 2 & $-2,24$ & $-0,92$ & 3,59 & $-2,52$ & 2,53 & 3,25 & $-0,29$ & $-5,33^{* *}$ & $\mathrm{I}(1)$ \\
\hline PSC & 1 & $-3,09$ & $-1,15$ & 5,24 & $-3,01$ & $2,90^{* *}$ & 4,53 & $-0,72$ & $-7,87^{* *}$ & $\mathrm{I}(1)$ \\
\hline LRS & 0 & $-1,88$ & $-1,47$ & 3,25 & $-2,04$ & 2,05 & 2,17 & $-0,33$ & $-6,68^{* *}$ & $\mathrm{I}(1)$ \\
\hline PRS & 0 & $-2,39$ & $-2,18$ & 3,96 & $-1,68$ & 1,55 & 1,41 & $-0,62$ & $-6,36^{* *}$ & $\mathrm{I}(1)$ \\
\hline
\end{tabular}

Fonte: Resultados da pesquisa.

** Significativo a 5\% considerando os valores críticos em Fuller (1976) e Dickey \& Fuller (1981) e para amostra com 25 observações.

Modelo $1 \Rightarrow \Delta x_{t}=\alpha+\beta t+\gamma x_{t-1}+\sum_{i=1}^{p-1} \lambda_{i} \Delta x_{t-i}+\varepsilon_{t}$, nas versões com constante e tendência, sem tendência e sem tendência e constante.

Modelo $2 \Rightarrow \Delta \Delta x_{t}=\gamma \Delta x_{t-1}+\sum_{i=1}^{p-2} \lambda_{\varphi} \Delta \Delta x_{t-i}+\varepsilon_{t}$, definido após constatar-se a não existência de termos deterministas.

Nota: não houve presença de autocorrelação serial, conforme o teste $Q$ de Ljung Box.

Os resultados dos testes de DF e ADF mostraram que todas as séries são I(1), ou seja, é necessária uma diferença a fim de que se tornem estacionárias. Para as séries de preços de terras de lavoura no Paraná e no Rio Grande do Sul, utilizou-se o teste de Dickey Fuller. Para as demais séries de preços de terra, a fim de se eliminar o problema de auto-correlação dos resíduos, utilizou-se o teste de Dickey Fuller Aumentado. 
De maneira semelhante à Tabela anterior, ressalta-se que nas séries de preços de terra de lavoura em Goiás, Mato Grosso e Paraná, e nas séries de preços de terra de pecuária em Goiás, Mato Grosso, Paraná e Santa Catarina, rejeitou-se a hipótese de que a constante seja zero, segundo o valor crítico apontado pela estatística $\tau_{\alpha \mu}$. (modelo 1 sem tendência). Entretanto, segundo a estatística $\phi_{1}$, nenhum dos modelos foi significativo, ou seja, não se pôde rejeitar a hipótese conjunta de que $\tau_{\mu}$ e $\tau_{\alpha \mu}$ sejam iguais a zero em nenhum dos modelos especificados. Desta maneira, seguiram-se os procedimentos e concluiu-se que as séries em questão têm uma raiz unitária.

\subsection{Resultados dos testes de co-integração}

Tendo sido observado que os resultados dos testes de Dickey Fuller e Dickey Fuller Aumentado indicaram que todas as variáveis são I(1), ou seja, têm uma raiz unitária, foram utilizados os testes de co-integração entre as variáveis, seguindo a metodologia proposta por Johansen (1988).

A seguir, na Tabela 28 está o resultado do teste de co-integração entre as séries de preços de terra de cultura de primeira, de cultura de segunda, de pastagem, de reflorestamento e de campo no estado de São Paulo. Em seguida, o resultado do teste foi analisado.

Tabela 28. Resultados do teste de co-integração de Johansen entre as séries de preços de terra de cultura de primeira, de cultura de segunda, de pastagem, de reflorestamento e de campo, no estado de São Paulo (1969-2001).

\begin{tabular}{cccc}
\hline Hipótese Nula & Hipótese Alternativa & $\ddot{\mathbf{e}}_{\text {max }}$ & $\ddot{\mathbf{e}}_{\text {trace }}$ \\
\hline $\mathrm{r} \leq 4$ & $\mathrm{r}=5$ & 4,57 & 4,57 \\
$\mathrm{r} \leq 3$ & $\mathrm{r}=4$ & 8,92 & 13,49 \\
$\mathrm{r} \leq 2$ & $\mathrm{r}=3$ & 15,32 & 28,81 \\
$\mathrm{r} \leq 1$ & $\mathrm{r}=2$ & 26,90 & $55,71^{* * *}$ \\
$\mathrm{r} \leq 0$ & $\mathrm{r}=1$ & $68,71^{* *}$ & $124,42^{* *}$ \\
\hline
\end{tabular}

Fonte: Resultados da pesquisa.

** Significativo a 5\% de significância [valores críticos em Enders (1995)]. Modelo com constante restrita, ajustado com duas defasagens. 
Seguindo o teste do $\ddot{\mathbf{e}}_{\text {trace }}$, rejeita-se a hipótese nula de que existe lou nenhum vetor de co-integração e aceita-se (ou não se rejeita) a hipótese alternativa de que existem dois vetores de co-integração entre as séries em estudo. Contudo, o objetivo era verificar se as séries eram co-integradas; mesmo que o resultado do teste indicasse somente um vetor de co-integração entre estas séries, tal resultado já seria suficiente para o objetivo pretendido. Valores dos testes significativos indicam que existem relações estacionárias entre as séries em estudo.

Conforme o esperado, existe relação estável significativa entre os preços de venda de terra de diferentes categorias, dentro do estado de São Paulo. Comprova-se que existe mobilidade dos indivíduos que demandam terra com finalidade agrícola. As 'novas' terras são incorporadas ao processo produtivo na medida que vão se tornando escassas e que as inovações agronômicas permitam a utilização de dessas 'novas' terras anteriormente inaptas ao cultivo.

Resta ainda verificar se esta relação pode ser extrapolada para regiões, ou seja, se os preços de diferentes categorias de terra do estado de São Paulo também apresentam relação de equilíbrio de longo prazo com o preço destas categorias de terra em outros estados. Para tanto, os resultados dos testes de co-integração estão nas Tabelas 29 a 36.

Tabela 29. Resultados do teste de co-integração de Johansen entre as séries de preços de terra de cultura de primeira (SP), de pastagem (SP), de lavoura (GO) e de pastagem (GO) (1969-2001).

\begin{tabular}{cccc}
\hline Hipótese Nula & Hipótese Alternativa & $\ddot{\mathbf{e}}_{\max }$ & $\ddot{\mathbf{e}}_{\text {trace }}$ \\
\hline $\mathrm{r} \leq 3$ & $\mathrm{r}=4$ & 7,66 & 7,66 \\
$\mathrm{r} \leq 2$ & $\mathrm{r}=3$ & 21,71 & 29,37 \\
$\mathrm{r} \leq 1$ & $\mathrm{r}=2$ & $38,00^{* *}$ & $67,36^{* *}$ \\
$\mathrm{r} \leq 0$ & $\mathrm{r}=1$ & $44,29^{* *}$ & $111,65^{* *}$ \\
\hline
\end{tabular}

Fonte: Resultados da pesquisa.

** Significativo a 5\% de significância [valores críticos em Enders (1995)]. Modelo com constante restrita, ajustado com cinco defasagens.

Conforme o teste do $\ddot{\mathbf{e}}_{\text {trace }}$, rejeita-se a hipótese nula de que existe 0 ou 1 vetor de co-integração entre os preços de venda de terra de cultura de primeira e de pastagem 
em São Paulo e preços de venda de terra de lavoura e de pastagem em Goiás. Não se rejeita, portanto, a hipótese alternativa de que existam dois vetores de co-integração entre as variáveis em análise. $\mathrm{O}$ teste do $\ddot{\mathbf{e}}_{\max }$ confirma este resultado.

A Tabela 30 apresenta os resultados do teste de co-integração entre os preços das mesmas categorias de terras citadas na Tabela anterior, porém entre os estados de São Paulo e Mato Grosso.

Tabela 30. Resultados do teste de co-integração de Johansen entre as séries de preços de terra de cultura de primeira (SP), de pastagem (SP), de lavoura (MT) e de pastagem (MT) (1969-2001).

\begin{tabular}{cccc}
\hline Hipótese Nula & Hipótese Alternativa & $\ddot{\mathbf{e}}_{\max }$ & $\ddot{\mathbf{e}}_{\text {trace }}$ \\
\hline $\mathrm{r} \leq 3$ & $\mathrm{r}=4$ & 3,79 & 3,79 \\
$\mathrm{r} \leq 2$ & $\mathrm{r}=3$ & 10,09 & 13,88 \\
$\mathrm{r} \leq 1$ & $\mathrm{r}=2$ & 17,54 & 31,42 \\
$\mathrm{r} \leq 0$ & $\mathrm{r}=1$ & $35,71^{* *}$ & $67,13^{* *}$ \\
\hline
\end{tabular}

Fonte: Resultados da pesquisa.

** Significativo a 5\% de significância [valores críticos em Enders (1995)]. Modelo com constante restrita, ajustado com duas defasagens.

Os resultados dos testes $\ddot{\mathbf{e}}_{\text {trace }}$ e $\ddot{\mathbf{e}}_{\text {max }}$ indicam que existe um vetor de co-integração entre os preços de venda da terra de cultura de primeira (SP), de pastagem (SP), de lavoura (MT) e de pastagem (MT).

Na Tabela 31 estão os resultados do teste de co-integração entre os preços das mesmas categorias de terra citadas na Tabela anterior, porém entre os estados de São Paulo e Rio de Janeiro. 
Tabela 31. Resultados do teste de co-integração de Johansen entre as séries de preços de terra de cultura de primeira (SP), de pastagem (SP), de lavoura (RJ) e de pastagem (RJ) (1969-2001).

\begin{tabular}{cccc}
\hline Hipótese Nula & Hipótese Alternativa & $\ddot{\mathbf{e}}_{\max }$ & $\ddot{\mathbf{e}}_{\text {trace }}$ \\
\hline $\mathrm{r} \leq 3$ & $\mathrm{r}=4$ & 5,35 & 5,35 \\
$\mathrm{r} \leq 2$ & $\mathrm{r}=3$ & 9,50 & 14,85 \\
$\mathrm{r} \leq 1$ & $\mathrm{r}=2$ & 13,38 & 28,23 \\
$\mathrm{r} \leq 0$ & $\mathrm{r}=1$ & $30,10^{* *}$ & $58,33^{* *}$ \\
\hline
\end{tabular}

Fonte: Resultados da pesquisa.

** Significativo a 5\% de significância [valores críticos em Enders (1995)]. Modelo com constante restrita, ajustado com duas defasagens.

Os preços de venda de terra de lavoura e de pecuária no estado do Rio de Janeiro são co-integrados com os preços de venda de terra de cultura de primeira e terra de pastagem no estado de São Paulo. Segundo as estatísticas $\ddot{\mathbf{e}}_{\text {trace }}$ e $\ddot{\mathbf{e}}_{\text {max }}$, existe uma relação estacionária entre estas séries.

Na Tabela 32 estão os resultados do teste de co-integração entre os preços das mesmas categorias de terras citadas na Tabela anterior, porém entre os estados de São Paulo e Espírito Santo.

Tabela 32. Resultados do teste de co-integração de Johansen entre as séries de preços de terra de cultura de primeira (SP), de pastagem (SP), de lavoura (ES) e de pastagem (ES) (1969-2001).

\begin{tabular}{cccc}
\hline Hipótese Nula & Hipótese Alternativa & $\ddot{\mathbf{e}}_{\max }$ & $\ddot{\mathbf{e}}_{\text {trace }}$ \\
\hline $\mathrm{r} \leq 3$ & $\mathrm{r}=4$ & 7,53 & 7,53 \\
$\mathrm{r} \leq 2$ & $\mathrm{r}=3$ & 8,09 & 15,62 \\
$\mathrm{r} \leq 1$ & $\mathrm{r}=2$ & 14,67 & 30,29 \\
$\mathrm{r} \leq 0$ & $\mathrm{r}=1$ & 26,20 & $56,49^{* *}$ \\
\hline
\end{tabular}

Fonte: Resultados da pesquisa.

** Significativo a 5\% de significância [valores críticos em Enders (1995)]. Modelo com constante restrita, ajustado com duas defasagens. 
Conforme o resultado do teste $\ddot{\mathbf{e}}_{\text {trace }}$, existe uma relação estacionária entre os preços de venda de terra de pastagem e de lavoura no Espírito Santo e preço de terra de cultura de primeira e de pastagem em São Paulo.

A Tabela 33 apresenta os resultados do teste de co-integração entre os preços das mesmas categorias de terras citadas na Tabela anterior, porém entre os estados de São Paulo e Minas Gerais.

Tabela 33. Resultados do teste de co-integração de Johansen entre as séries de preços de terra de cultura de primeira (SP), de pastagem (SP), de lavoura (MG) e de pastagem (MG) (1969-2001).

\begin{tabular}{cccc}
\hline Hipótese Nula & Hipótese Alternativa & $\ddot{\mathbf{e}}_{\max }$ & $\ddot{\mathbf{e}}_{\text {trace }}$ \\
\hline $\mathrm{r} \leq 3$ & $\mathrm{r}=4$ & 5,142 & 5,14 \\
$\mathrm{r} \leq 2$ & $\mathrm{r}=3$ & 9,29 & 14,43 \\
$\mathrm{r} \leq 1$ & $\mathrm{r}=2$ & 13,52 & 27,95 \\
$\mathrm{r} \leq 0$ & $\mathrm{r}=1$ & $32,98^{* *}$ & $60,92^{* *}$ \\
\hline
\end{tabular}

Fonte: Resultados da pesquisa.

** Significativo a 5\% de significância [valores críticos em Enders (1995)]. Modelo com constante restrita, ajustado com duas defasagens.

Os preços de venda da terra de cultura de primeira e terra de pastagem em São Paulo são co-integrados com os preços de venda das terras das categorias lavoura e pastagem no estado de Minas Gerais. Conforme os resultados dos testes $\ddot{\mathbf{e}}_{\text {trace }} \mathrm{e}$ $\ddot{\mathbf{e}}_{\text {max }}$, existe uma combinação estacionária entre estas séries.

Na Tabela 34 estão os resultados do teste de co-integração entre os preços das mesmas categorias de terras citadas na Tabela anterior, porém entre os estados de São Paulo e Paraná. 
Tabela 34. Resultados do teste de co-integração de Johansen entre as séries de preços de terra de cultura de primeira (SP), de pastagem (SP), de lavoura (PR) e de pastagem (PR) (1969-2001).

\begin{tabular}{cccc}
\hline Hipótese Nula & Hipótese Alternativa & $\ddot{\mathbf{e}}_{\max }$ & $\ddot{\mathbf{e}}_{\text {trace }}$ \\
\hline $\mathrm{r} \leq 3$ & $\mathrm{r}=4$ & 2,89 & 2,89 \\
$\mathrm{r} \leq 2$ & $\mathrm{r}=3$ & 5,92 & 8,81 \\
$\mathrm{r} \leq 1$ & $\mathrm{r}=2$ & 11,79 & 20,59 \\
$\mathrm{r} \leq 0$ & $\mathrm{r}=1$ & 26,53 & 47,12 \\
\hline
\end{tabular}

Fonte: Resultados da pesquisa.

** Significativo a 5\% de significância [valores críticos em Enders (1995)]. Modelo com constante restrita, ajustado com duas defasagens.

Diferentemente dos demais estados, os preços de venda da terra de lavoura e de pastagem no Paraná não são co-integrados com os preços da terra de cultura de primeira e de pastagem do estado de São Paulo, conforme os resultados obtidos pelo teste de cointegração. Contudo, deve-se ressaltar que não se pode inferir que não existe relação entre os preços de venda da terra entre esses estados.

Na Tabela 35 estão os resultados do teste de co-integração entre os preços das mesmas categorias de terras citadas na Tabela anterior, porém entre os estados de São Paulo e Santa Catarina.

Tabela 35. Resultados do teste de co-integração de Johansen entre as séries de preços de terra de cultura de primeira (SP), de pastagem (SP), de lavoura (SC) e de pastagem (SC) (1969-2001).

\begin{tabular}{cccc}
\hline Hipótese Nula & Hipótese Alternativa & $\ddot{\mathbf{e}}_{\text {max }}$ & $\ddot{\mathbf{e}}_{\text {trace }}$ \\
\hline $\mathrm{r} \leq 3$ & $\mathrm{r}=4$ & 4,68 & 4,68 \\
$\mathrm{r} \leq 2$ & $\mathrm{r}=3$ & 8,76 & 13,44 \\
$\mathrm{r} \leq 1$ & $\mathrm{r}=2$ & 20,63 & 34,07 \\
$\mathrm{r} \leq 0$ & $\mathrm{r}=1$ & $41,42^{* *}$ & $75,49^{* *}$ \\
\hline
\end{tabular}

Fonte: Resultados da pesquisa.

** Significativo a 5\% de significância [valores críticos em Enders (1995)]. Modelo com constante restrita, ajustado com duas defasagens. 
Os preços de terra das categorias em questão e dos estados de Santa Catarina e São Paulo são co-integrados. As estatísticas $\ddot{\mathbf{e}}_{\text {trace }}$ e $\ddot{\mathbf{e}}_{\max }$ indicaram que existe uma relação estacionária entre as séries em análise.

Na Tabela 36 estão os resultados do teste de co-integração entre os preços das mesmas categorias de terras citadas na Tabela anterior, porém entre os estados de São Paulo e Rio Grande do Sul.

Tabela 36. Resultados do teste de co-integração de Johansen entre as séries de preços de terra de cultura de primeira (SP), de pastagem (SP), de lavoura (RS) e de pastagem (RS) (1969-2001).

\begin{tabular}{cccc}
\hline Hipótese Nula & Hipótese Alternativa & $\ddot{\mathbf{e}}_{\max }$ & $\ddot{\mathbf{e}}_{\text {trace }}$ \\
\hline $\mathrm{r} \leq 3$ & $\mathrm{r}=4$ & 3,81 & 3,81 \\
$\mathrm{r} \leq 2$ & $\mathrm{r}=3$ & 8,19 & 12,00 \\
$\mathrm{r} \leq 1$ & $\mathrm{r}=2$ & 16,37 & 28,37 \\
$\mathrm{r} \leq 0$ & $\mathrm{r}=1$ & $28,35^{* *}$ & $56,73^{* *}$ \\
\hline
\end{tabular}

Fonte: Resultados da pesquisa.

** Significativo a 5\% de significância [valores críticos em Enders (1995)]. Modelo com constante restrita, ajustado com três defasagens.

Os preços de terra de lavoura e de pastagem no Rio Grande do Sul mostraramse co-integrados com os preços de terra de cultura de primeira e de pastagem no estado de São Paulo. Os testes $\ddot{\mathbf{e}}_{\text {trace }}$ e $\ddot{\mathbf{e}}_{\text {max }}$ mostraram a existência de um vetor de co-integração entre estas séries.

De maneira geral, os testes comprovaram as evidências empíricas de que há relação entre os preços de venda de terras de diferentes categorias, dentro do estado e entre estados.

Os resultados obtidos dos testes de co-integração (tanto para os preços de terra dentro do estado como entre os estados) fazem sentido tanto do ponto de vista do setor agrícola como sob a ótica macroeconômica. 
Primeiramente, sabe-se que existe mobilidade dos indivíduos que demandam terra com finalidade agrícola. Esta mobilidade pode se dar tanto dentro de um estado (na medida que as terras mais férteis vão tornando-se escassas) quanto entre estados ou regiões (inovações agronômicas tornando aptas as terras anteriormente inaptas ao cultivo). $\mathrm{O}$ cerrado brasileiro é um exemplo dessa migração.

Um outro argumento em favor da co-integração dos preços de terra dentro do estado e entre estados tem origem macroeconômica. Os anos de alta inflacionária, insuficiência do mercado financeiro e incerteza quanto aos planos econômicos criaram uma demanda por terras com finalidade especulativa, como mostraram os estudos referenciados. Muitos agentes sem envolvimento com a atividade agropecuária passaram a demandar terras, nessas fases, com a finalidade de reserva de valor.

$\mathrm{O}$ argumento da demanda por terras com a finalidade especulativa somado ao argumento da mobilidade dos agentes que demandam terras para fins agrícolas justificam os resultados obtidos pelos testes de co-integração.

O próximo capítulo traz as principais conclusões obtidas dos resultados deste trabalho. 


\section{CONCLUSÕES}

Segundo a teoria econômica, o preço da terra deve refletir o valor presente dos fluxos de receitas que este fator pode gerar. Contudo, diversas pesquisas, principalmente nas décadas de 70 e 80 verificaram que os determinantes do preço da terra iam além do valor do arrendamento e da taxa de juro. Tais pesquisas indicaram que variáveis macroeconômicas como taxa de inflação, hiato do produto, infra-estrutura governamental e outras variáveis como o crédito rural foram elementos cruciais para explicar a variação dos preços da terra no período. Em muitos estudos, argumentou-se que a terra havia incorporado outros papéis, além do fator de produção.

Balizado pelas diversas correntes que surgiram dos estudos sobre a formação do preço da terra, este estudo analisou quais foram os principais determinantes dos preços da terra de cultura de primeira, terra para pastagem, arrendamento para culturas e do aluguel de pasto para animais, no estado de São Paulo, no período de 1969 a 2001. Em seguida, procurou-se testar a relação existente entre os preços das diversas categorias de terras existentes no estado de São Paulo, e entre os preços das categorias lavoura e pastagem do estado de São Paulo com os preços dessas mesmas categorias em outros estados do Centro-Sul do país.

Os preços de venda da terra de cultura e de pastagem exibiram determinantes muito próximos. Tais determinantes foram: poder de compra do agricultor ou índices de preços recebidos e de preços pagos (ambos defasados em um ano), volume de subsídio concedido através do crédito rural, taxa de inflação, infra-estrutura governamental (medida pela extensão das rodovias federal, estadual e municipal) e hiato do produto. A 
taxa de juro real foi significativa em uma das estimativas dos determinantes do preço de venda de terra para pastagem.

Os determinantes dos preços de arrendamento foram: índice de paridade ou índices de preços recebidos e de preços pagos, taxa de inflação, hiato do produto, taxa de juro real e volume de subsídio concedido através do crédito rural (somente para aluguel de pastagem).

Utilizou-se uma variável binária nas análises dos determinantes de todos os preços de terra em estudo, a qual mostrou que houve deslocamento significativo do intercepto dos preços de venda de terra e de arrendamento (para as duas categorias em estudo), no período de 1973-94.

O volume de subsídio concedido através do crédito rural apresentou maior influência sobre os preços de venda da terra de pastagem que da terra de culturas. Além disso, essa variável foi um dos determinantes do aluguel de pasto.

A taxa de juro influenciou negativamente os preços de venda da terra de pastagem e de arrendamento para culturas e pastagem.

A taxa de inflação afetou positivamente os preços de venda das duas categorias de terra em estudo, assim como o valor do arrendamento para culturas e para pastagem.

A variável utilizada como proxy da infra-estrutura (RODO) apresentou relação positiva com os preços de venda da terra de cultura e de pastagem. Entretanto, não foi significativa em nenhuma das regressões estimadas para preço de arrendamento.

O hiato do produto é um componente que, além de variar em sentido oposto ao dos preços de venda e dos valores de arrendamento (tanto para culturas como para pastagem), mostrou-se significativo na determinação de todos estes preços. Vale ressaltar que, embora o comportamento do hiato varie em sentido oposto ao dos preços de venda de terras e do valor do arrendamento, o nível de atividade econômica afeta diretamente esses preços. 
Embora o preço do aluguel para pasto tenha exibido comportamento mais elástico com relação às variáveis explicativas selecionadas, algumas regressões estimadas para valor de arrendamento para culturas apresentaram maior coeficiente de determinação. Dessa afirmação, há a hipótese de que existem outros fatores, os quais não foram incluídos neste estudo, que complementem a explicação dos determinantes dos preços do aluguel de terras para pastagem, como por exemplo, o preço da arroba do boi.

Este trabalho verificou a importância e a maior sensibilidade das variáveis relacionadas à atividade agrícola na determinação dos preços da terra, em detrimento das variáveis macroeconômicas e do crédito rural. Contudo, não deixa de enfatizar que as variáveis indiretamente ligadas à atividade agrícola (como taxa de inflação, taxa de juro e hiato do produto) também tiveram participação e responsabilidade na variação dos preços do fator em questão.

Uma última consideração pode ser ressaltada em relação ao fato de os preços de venda de dois diferentes tipos de terra serem explicados, em alguns casos, pelos mesmos regressores e, ainda, apresentarem graus de ajuste muito próximos. Estes preços apresentaram comportamentos semelhantes no tempo, o que poderia ser um indício de que existe um equilíbrio estável de longo prazo entre os fatores de diferentes categorias.

Os resultados dos testes suportaram as evidências empíricas de que os preços de diferentes tipos de terra, em diferentes regiões, estão relacionados. A explanação destes resultados emerge de dois lados: da demanda por terras com a finalidade agrícola e da demanda por terras para fins especulativos.

A mobilidade dos indivíduos que demandam terras com a finalidade agrícola pode se dar tanto dentro de um estado (na medida que as terras mais férteis vão tornando-se escassas) quanto entre estados ou regiões (inovações agronômicas tornando aptas as terras anteriormente inaptas ao cultivo). 
O segundo argumento a favor da relação dos preços de terra dentro do estado e entre estados tem origem macroeconômica. Os anos de alta inflacionária, insuficiência do mercado fnanceiro e incerteza quanto aos planos econômicos criaram uma demanda por terras com finalidade especulativa, como mostraram os estudos referenciados. Muitos agentes sem envolvimento com a atividade agropecuária passaram a demandar terras, nessas fases, com a finalidade de reserva de valor.

$\mathrm{O}$ argumento da demanda por terras com a finalidade especulativa somado ao argumento da mobilidade dos agentes que demandam terras para fins agrícolas justificaram as expectativas de que os preços de terra de diversas categorias e regiões estejam relacionados.

Este trabalho indicou quais foram os possíveis determinantes dos preços de venda da terra e do arrendamento de terras, no período de 1969 a 2001. Procurou mostrar ainda, que os preços de venda da terra de diferentes categorias e em diferentes estados estão, por alguns motivos, interligados.

Por fim, realça-se que outros estudos sobre o mercado de terras deveriam vir à tona, a fim de contribuírem como suporte para políticas que propiciem, entre outras causas, o não distanciamento da terra de seu papel fundamental: fator de produção. 
ANEXOS 
ANEXO A - Dados utilizados na pesquisa.

\begin{tabular}{|c|c|c|c|c|}
\hline & PTCULT & PTPAST & ARCULT & ARPAST \\
\hline & $\mathrm{R} \$ \operatorname{dez} 01 / \mathrm{ha}$ & $\mathrm{R} \$ \operatorname{dez} 01 / \mathrm{ha}$ & $\mathrm{R} \$ \operatorname{dez} 01 / \mathrm{ha}$ & $\mathrm{R} \$ \operatorname{dez} 01 / \mathrm{ha}$ \\
\hline 1969 & 1919,95 & 1261,68 & 221,14 & 93,87 \\
\hline 1970 & 2539,82 & 1385,36 & 210,36 & 104,38 \\
\hline 1971 & 2979,49 & 1678,64 & 229,89 & 149,76 \\
\hline 1972 & 3210,73 & 1926,44 & 260,69 & 176,62 \\
\hline 1973 & 4614,60 & 2796,73 & 384,89 & 188,63 \\
\hline 1974 & 8951,25 & 5182,31 & 375,30 & 213,85 \\
\hline 1975 & 9085,97 & 5768,31 & 368,28 & 263,88 \\
\hline 1976 & 10003,71 & 6340,57 & 380,05 & 230,91 \\
\hline 1977 & 10087,58 & 5719,95 & 354,71 & 207,40 \\
\hline 1978 & 9885,25 & 5882,43 & 367,61 & 214,55 \\
\hline 1979 & 9024,69 & 6615,61 & 327,18 & 221,00 \\
\hline 1980 & 9407,15 & 6716,07 & 371,16 & 201,41 \\
\hline 1981 & 9981,19 & 6985,92 & 417,75 & 188,65 \\
\hline 1982 & 9048,05 & 5904,85 & 362,56 & 172,66 \\
\hline 1983 & 6624,99 & 4384,48 & 261,21 & 142,82 \\
\hline 1984 & 6936,12 & 4538,02 & 322,89 & 152,14 \\
\hline 1985 & 8720,86 & 5821,42 & 383,63 & 164,86 \\
\hline 1986 & 14589,93 & 9608,71 & 504,28 & 230,82 \\
\hline 1987 & 12369,37 & 7740,91 & 272,85 & 196,36 \\
\hline 1988 & 6235,82 & 3954,65 & 245,12 & 122,49 \\
\hline 1989 & 8257,59 & 5597,79 & 222,46 & 211,51 \\
\hline 1990 & 7107,69 & 4694,65 & 267,78 & 144,61 \\
\hline 1991 & 6377,74 & 4109,25 & 238,60 & 158,93 \\
\hline 1992 & 5218,23 & 3371,28 & 236,65 & 122,77 \\
\hline 1993 & 6145,40 & 4075,67 & 277,75 & 121,46 \\
\hline 1994 & 8049,95 & 5440,26 & 268,16 & 124,99 \\
\hline 1995 & 8105,86 & 5395,64 & 204,84 & 119,46 \\
\hline 1996 & 5371,63 & 3387,18 & 208,24 & 102,79 \\
\hline 1997 & 4516,72 & 2796,64 & 218,45 & 94,45 \\
\hline 1998 & 4208,36 & 2597,51 & 202,96 & 93,73 \\
\hline 1999 & 3943,85 & 2404,92 & 196,66 & 87,69 \\
\hline 2000 & 4054,88 & 2509,95 & 189,24 & 84,36 \\
\hline 2001 & 4579,87 & 2905,88 & 199,10 & 87,88 \\
\hline Média & 7034,98 & 4530,29 & 289,47 & 157,32 \\
\hline
\end{tabular}

Fonte: IEA 
ANEXO B - Continuação dos dados utilizados na pesquisa.

\begin{tabular}{|c|c|c|c|c|c|c|c|c|c|c|c|}
\hline & $\begin{array}{c}\text { VCRSU } \\
\text { B }\end{array}$ & IPR & IPP & IP & $\mathrm{PC}$ & HIATO & TINF & $\mathrm{TJ}$ & RODO & BINR & BIN \\
\hline & $\begin{array}{l}\text { mil R\$ } \\
\text { dez/01 }\end{array}$ & & & & & & $\%$ & & & & \\
\hline 1969 & 99,11 & 79,01 & 89,28 & 88,49 & 59,21 & 0,01374 & 19,31 & - & 165169 & 0 & 0 \\
\hline 1970 & 122,39 & 84,71 & 90,61 & 93,48 & 79,36 & 0,04744 & 19,26 & - & 171752 & 0 & 0 \\
\hline 1971 & 168,27 & 86,81 & 95,48 & 90,93 & 64,63 & 0,07597 & 19,47 & - & 178292 & 0 & 0 \\
\hline 1972 & 35,56 & 95,58 & 102,67 & 93,10 & 76,27 & 0,05731 & 15,72 & - & 182931 & 0 & 0 \\
\hline 1973 & 71,96 & 121,02 & 119,37 & 101,39 & 80,67 & 0,05897 & 15,54 & - & 170554 & 0 & 1 \\
\hline 1974 & 1967,51 & 120,19 & 141,68 & 84,83 & 55,41 & 0,01831 & 34,55 & 12,84 & 172340 & 0 & 1 \\
\hline 1975 & 1901,05 & 121,29 & 131,49 & 92,24 & 62,04 & 0,00757 & 29,35 & 5,79 & 176848 & 0 & 1 \\
\hline 1976 & 3438,74 & 143,52 & 119,91 & 119,69 & 92,31 & 0,01028 & 46,26 & 3,49 & 213965 & 1 & 1 \\
\hline 1977 & 2451,86 & 157,01 & 116,78 & 134,45 & 111,27 & 0,05112 & 38,78 & 2,27 & 214364 & 1 & 1 \\
\hline 1978 & 1498,60 & 134,51 & 128,37 & 104,78 & 81,06 & 0,06123 & 40,81 & 3,97 & 235163 & 1 & 1 \\
\hline 1979 & 6245,47 & 134,62 & 145,01 & 92,84 & 73,82 & 0,01104 & 77,25 & 19,56 & 169520 & 0 & 1 \\
\hline 1980 & 5957,44 & 133,93 & 150,16 & 89,19 & 76,13 & 0,00563 & 110,24 & 30,39 & 169752 & 0 & 1 \\
\hline 1981 & 3431,70 & 108,12 & 130,44 & 82,89 & 66,75 & 0,03971 & 95,20 & 3,03 & 169741 & 0 & 1 \\
\hline 1982 & 3739,02 & 92,67 & 112,53 & 82,35 & 75,41 & 0,14720 & 99,72 & 9,83 & 169801 & 0 & 1 \\
\hline 1983 & 2797,27 & 103,23 & 117,06 & 88,19 & 84,54 & 0,15312 & 210,99 & 5,73 & 170134 & 0 & 1 \\
\hline 1984 & 54,21 & 110,63 & 119,72 & 92,41 & 91,82 & 0,23361 & 223,81 & 1,64 & 194606 & 0 & 1 \\
\hline 1985 & 94,88 & 112,53 & 210,24 & 53,52 & 84,89 & 0,08210 & 235,11 & 2,76 & 193946 & 0 & 1 \\
\hline 1986 & 3740,66 & 152,45 & 132,28 & 115,25 & 108,26 & 0,58214 & 65,03 & 7,29 & 193471 & 0 & 1 \\
\hline 1987 & 166,26 & 85,00 & 114,03 & 74,55 & 117,51 & 0,06473 & 415,83 & 12,17 & 194899 & 0 & 1 \\
\hline 1988 & 673,14 & 75,85 & 97,67 & 77,66 & 76,06 & 0,31087 & 1037,56 & 1,77 & 194908 & 0 & 1 \\
\hline 1989 & 1881,71 & 82,69 & 106,29 & 77,80 & 75,94 & 0,34372 & 1782,89 & 33,16 & 194818 & 0 & 1 \\
\hline 1990 & 502,45 & 64,54 & 108,96 & 59,23 & 59,36 & 0,22540 & 1476,71 & 20,52 & 194819 & 0 & 1 \\
\hline 1991 & 370,77 & 64,19 & 108,03 & 59,41 & 60,62 & 0,19776 & 480,23 & 9,76 & 194819 & 0 & 1 \\
\hline 1992 & 373,68 & 75,89 & 129,83 & 58,45 & 59,44 & 0,16850 & 1157,84 & 31,13 & 193258 & 0 & 1 \\
\hline 1993 & 79,44 & 78,94 & 129,36 & 61,03 & 62,76 & 0,48299 & 2708,17 & 12,53 & 195027 & 0 & 1 \\
\hline 1994 & 137,24 & 78,55 & 115,02 & 68,30 & 69,22 & 0,05934 & 1093,89 & 5,01 & 195027 & 0 & 1 \\
\hline 1995 & 251,64 & 60,42 & 92,64 & 65,22 & 66,52 & 0,20467 & 14,78 & 33,37 & 195026 & 0 & 0 \\
\hline 1996 & 7,17 & 62,22 & 91,06 & 68,33 & 71,39 & 0,07480 & 9,34 & 16,53 & 195026 & 0 & 0 \\
\hline 1997 & 54,47 & 68,29 & 90,86 & 75,16 & 80,01 & 0,05380 & 7,48 & 16,10 & 195026 & 0 & 0 \\
\hline 1998 & 321,50 & 74,02 & 90,50 & 81,79 & 88,12 & 0,07514 & 1,70 & 26,63 & 195049 & 0 & 0 \\
\hline 1999 & 237,68 & 68,30 & 96,24 & 70,97 & 78,43 & 0,06233 & 19,98 & 4,67 & 195071 & 0 & 0 \\
\hline 2000 & 27,77 & 73,33 & 95,68 & 76,64 & 82,28 & 0,01372 & 9,81 & 6,96 & 195071 & 0 & 0 \\
\hline 2001 & 51,89 & 91,16 & 98,12 & 92,90 & 100,00 & 0,00843 & 10,40 & 6,27 & 195071 & 0 & 0 \\
\hline Média & 1200,26 & 96,82 & 115,68 & 83,86 & 77,92 & 0,0077 & 352,21 & 3,38 & 188947 & & \\
\hline
\end{tabular}

Fonte: Resultados da pesquisa. 
ANEXO C - Continuação dos dados utilizados na pesquisa.

\begin{tabular}{|c|c|c|c|c|c|}
\hline & $\begin{array}{c}\text { Terra de } \\
\text { Cultura de } \\
\text { Primeira }\end{array}$ & $\begin{array}{c}\text { Terra de } \\
\text { Cultura de } \\
\text { segunda }\end{array}$ & $\begin{array}{l}\text { Terra para } \\
\text { Pastagem }\end{array}$ & $\begin{array}{c}\text { Terra para } \\
\text { Reflorestamento }\end{array}$ & Terra para Campo \\
\hline & $\mathrm{R} \$ \operatorname{dez} 01 / \mathrm{ha}$ & $\mathrm{R} \$$ dez01/ha & $\mathrm{R} \$ \mathrm{dez} 01 / \mathrm{ha}$ & $\mathrm{R} \$$ dez01/ha & $\mathrm{R} \$ \mathrm{dez} 01 / \mathrm{ha}$ \\
\hline 1969 & 1920 & 1426 & 1262 & 878 & 686 \\
\hline 1970 & 2540 & 1686 & 1385 & 1039 & 808 \\
\hline 1971 & 2979 & 2030 & 1679 & 1181 & 1002 \\
\hline 1972 & 3211 & 2248 & 1926 & 1340 & 1092 \\
\hline 1973 & 4615 & 3356 & 2797 & 1818 & 1678 \\
\hline 1974 & 8951 & 6831 & 5182 & 4358 & 3769 \\
\hline 1975 & 9086 & 6803 & 5768 & 4530 & 3795 \\
\hline 1976 & 10004 & 7459 & 6341 & 4582 & 4156 \\
\hline 1977 & 10088 & 7392 & 5720 & 4267 & 3710 \\
\hline 1978 & 9885 & 7586 & 5882 & 4674 & 4008 \\
\hline 1979 & 9025 & 7657 & 6616 & 5089 & 4960 \\
\hline 1980 & 9407 & 8008 & 6716 & 5170 & 4805 \\
\hline 1981 & 9981 & 8068 & 6986 & 6045 & 5737 \\
\hline 1982 & 9048 & 7110 & 5905 & 4788 & 4949 \\
\hline 1983 & 6625 & 5288 & 4384 & 3774 & 3332 \\
\hline 1984 & 6936 & 5322 & 4538 & 3322 & 3080 \\
\hline 1985 & 8721 & 6687 & 5821 & 4546 & 4356 \\
\hline 1986 & 14590 & 11331 & 9609 & 7861 & 7336 \\
\hline 1987 & 12369 & 9228 & 7741 & 6197 & 5877 \\
\hline 1988 & 6236 & 4639 & 3955 & 3095 & 3069 \\
\hline 1989 & 8258 & 6440 & 5598 & 4274 & 4249 \\
\hline 1990 & 7108 & 5476 & 4695 & 3864 & 3720 \\
\hline 1991 & 6378 & 4821 & 4109 & 3361 & 3394 \\
\hline 1992 & 5218 & 4032 & 3371 & 2607 & 2411 \\
\hline 1993 & 6145 & 4800 & 4076 & 3032 & 3060 \\
\hline 1994 & 8050 & 6348 & 5440 & 4159 & 4023 \\
\hline 1995 & 8106 & 6344 & 5396 & 4729 & 4364 \\
\hline 1996 & 5372 & 4074 & 3387 & 3091 & 2668 \\
\hline 1997 & 4517 & 3441 & 2797 & 2413 & 2011 \\
\hline 1998 & 4208 & 3219 & 2598 & 2171 & 1825 \\
\hline 1999 & 3944 & 2990 & 2405 & 2014 & 1662 \\
\hline 2000 & 4055 & 3087 & 2510 & 2044 & 1811 \\
\hline 2001 & 4580 & 3562 & 2906 & 2247 & 2038 \\
\hline
\end{tabular}

Fonte: IEA 
ANEXO D - Continuação dos dados utilizados na pesquisa.

\begin{tabular}{|c|c|c|c|c|c|c|c|c|}
\hline & LGO & PGO & LMT & PMT & LRJ & PRJ & LES & PES \\
\hline & $\begin{array}{c}\mathrm{R} \$ \\
\mathrm{dez} 01 / \mathrm{ha}\end{array}$ & $\begin{array}{c}\mathrm{R} \$ \\
\mathrm{dez} 01 / \mathrm{ha}\end{array}$ & $\begin{array}{c}\mathrm{R} \$ \\
\mathrm{dez} 01 / \mathrm{ha}\end{array}$ & $\begin{array}{c}\mathrm{R} \$ \\
\mathrm{dez} 01 / \mathrm{ha}\end{array}$ & $\begin{array}{c}\mathrm{R} \$ \\
\mathrm{dez} 01 / \mathrm{ha}\end{array}$ & $\begin{array}{c}\mathrm{R} \$ \\
\mathrm{dez} 01 / \mathrm{ha}\end{array}$ & $\begin{array}{c}\mathrm{R} \$ \\
\mathrm{dez} 01 / \mathrm{ha}\end{array}$ & $\begin{array}{c}\mathrm{R} \$ \\
\text { dez01/ha }\end{array}$ \\
\hline 1969 & 733 & 571 & 523 & 537 & 1241 & 1048 & 829 & 627 \\
\hline 1970 & 636 & 608 & 527 & 717 & 1246 & 1043 & 898 & 624 \\
\hline 1971 & 620 & 559 & 571 & 678 & 1262 & 1002 & 870 & 689 \\
\hline 1972 & 817 & 726 & 775 & 787 & 1019 & 958 & 854 & 851 \\
\hline 1973 & 1261 & 1224 & 1215 & 1183 & 1671 & 1486 & 1271 & 1149 \\
\hline 1974 & 1586 & 1648 & 1648 & 1670 & 3009 & 2464 & 2478 & 2304 \\
\hline 1975 & 1823 & 1848 & 2080 & 2157 & 3739 & 3368 & 3562 & 3359 \\
\hline 1976 & 1652 & 1603 & 1702 & 1875 & 4490 & 3741 & 3845 & 3561 \\
\hline 1977 & 1891 & 1355 & 1391 & 1119 & 5617 & 3886 & 4295 & 3106 \\
\hline 1978 & 1796 & 1363 & 1188 & 1105 & 5409 & 4134 & 3610 & 2876 \\
\hline 1979 & 2021 & 1333 & 1344 & 1264 & 4681 & 3503 & 3371 & 2706 \\
\hline 1980 & 2660 & 1692 & 1702 & 1210 & 4547 & 3609 & 3574 & 2985 \\
\hline 1981 & 2740 & 1816 & 1802 & 1273 & 4846 & 3212 & 4060 & 3006 \\
\hline 1982 & 2183 & 1565 & 1634 & 1137 & 5508 & 2956 & 4006 & 2655 \\
\hline 1983 & 1489 & 927 & 989 & 648 & 3914 & 1976 & 2747 & 1706 \\
\hline 1984 & 2542 & 1746 & 1623 & 1087 & 4088 & 2442 & 3265 & 2246 \\
\hline 1985 & 2404 & 1575 & 940 & 1097 & 4034 & 2325 & 4411 & 3058 \\
\hline 1986 & 6472 & 4682 & 3605 & 2441 & 11425 & 8271 & 13838 & 10067 \\
\hline 1987 & 2774 & 2045 & 2248 & 1660 & 6737 & 5048 & 5468 & 3904 \\
\hline 1988 & 1290 & 917 & 732 & 571 & 3837 & 2833 & 2260 & 1474 \\
\hline 1989 & 2706 & 1815 & 1318 & 1082 & 6315 & 4462 & 4584 & 3540 \\
\hline 1990 & 2523 & 1923 & 1048 & 860 & 5879 & 4560 & 3717 & 2963 \\
\hline 1991 & 2340 & 1971 & 909 & 813 & 4375 & 3325 & 2695 & 2420 \\
\hline 1992 & 1790 & 1390 & 457 & 631 & 2463 & 1681 & 1695 & 1607 \\
\hline 1993 & 2569 & 2120 & 117 & 832 & 2404 & 1724 & 2643 & 2243 \\
\hline 1994 & 3863 & 2976 & 1275 & 1043 & 3858 & 1751 & 5057 & 3841 \\
\hline 1995 & 2163 & 1869 & 1163 & 952 & 4190 & 2888 & 4308 & 3558 \\
\hline 1996 & 1409 & 1051 & 959 & 726 & 2401 & 1823 & 2559 & 1613 \\
\hline 1997 & 1234 & 906 & 872 & 650 & 2287 & 1684 & 1824 & 1198 \\
\hline 1998 & 1303 & 910 & 810 & 606 & 2198 & 1521 & 1605 & 1094 \\
\hline 1999 & 1392 & 843 & 790 & 584 & 2207 & 1504 & 1609 & 1068 \\
\hline 2000 & 1586 & 929 & 840 & 593 & 2146 & 1401 & 1819 & 1250 \\
\hline 2001 & 1899 & 1199 & 1132 & 720 & 2058 & 1368 & 1863 & 1353 \\
\hline
\end{tabular}

Fonte: FGV 
ANEXO E - Continuação dos dados utilizados na pesquisa.

\begin{tabular}{|c|c|c|c|c|c|c|c|c|}
\hline & LMG & PMG & LPR & PPR & LSC & PSC & LRS & PRS \\
\hline & $\begin{array}{c}\mathrm{R} \$ \\
\mathrm{dez} 01 / \mathrm{ha}\end{array}$ & $\begin{array}{c}\mathrm{R} \$ \\
\mathrm{dez} 01 / \mathrm{ha}\end{array}$ & $\begin{array}{c}\mathrm{R} \$ \\
\mathrm{dez} 01 / \mathrm{ha}\end{array}$ & $\begin{array}{c}\mathrm{R} \$ \\
\mathrm{dez} 01 / \mathrm{ha}\end{array}$ & $\begin{array}{c}\mathrm{R} \$ \\
\mathrm{dez} 01 / \mathrm{ha}\end{array}$ & $\begin{array}{c}\mathrm{R} \$ \\
\mathrm{dez} 01 / \mathrm{ha}\end{array}$ & $\begin{array}{c}\mathrm{R} \$ \\
\mathrm{dez} 01 / \mathrm{ha}\end{array}$ & $\begin{array}{c}\mathrm{R} \$ \\
\mathrm{dez} 01 / \mathrm{ha}\end{array}$ \\
\hline 1969 & 878 & 787 & 1081 & 887 & 1362 & 1102 & 989 & 1067 \\
\hline 1970 & 861 & 641 & 1102 & 855 & 1339 & 1103 & 1162 & 996 \\
\hline 1971 & 901 & 700 & 1085 & 882 & 1394 & 1183 & 1206 & 1206 \\
\hline 1972 & 946 & 785 & 1503 & 1250 & 1502 & 1414 & 1560 & 1494 \\
\hline 1973 & 1751 & 1364 & 2466 & 2136 & 1784 & 1677 & 2331 & 2069 \\
\hline 1974 & 2540 & 2151 & 3814 & 3484 & 2738 & 2577 & 3402 & 3187 \\
\hline 1975 & 2880 & 2519 & 4439 & 3446 & 3629 & 3176 & 4029 & 3610 \\
\hline 1976 & 2896 & 2377 & 4113 & 3522 & 3974 & 3026 & 4271 & 3902 \\
\hline 1977 & 3865 & 2500 & 8230 & 5290 & 4210 & 2838 & 4912 & 3587 \\
\hline 1978 & 3416 & 2370 & 6531 & 4582 & 3864 & 2590 & 4827 & 3243 \\
\hline 1979 & 3215 & 2191 & 6078 & 4351 & 3674 & 2466 & 4321 & 2973 \\
\hline 1980 & 3151 & 2276 & 6709 & 4755 & 3807 & 2679 & 4541 & 3451 \\
\hline 1981 & 3328 & 2363 & 8301 & 5265 & 4326 & 3072 & 4738 & 3600 \\
\hline 1982 & 2967 & 2029 & 7442 & 4759 & 4275 & 2733 & 5336 & 3765 \\
\hline 1983 & 2048 & 1324 & 5159 & 2901 & 3025 & 1648 & 4715 & 2775 \\
\hline 1984 & 2630 & 1980 & 7137 & 4294 & 2930 & 1909 & 5205 & 3081 \\
\hline 1985 & 3473 & 2212 & 8457 & 4585 & 3027 & 1902 & 4622 & 2433 \\
\hline 1986 & 10262 & 6802 & 16244 & 10430 & 7635 & 5448 & 6784 & 3908 \\
\hline 1987 & 4686 & 3384 & 6628 & 4528 & 4718 & 3228 & 5101 & 3051 \\
\hline 1988 & 1979 & 1368 & 4939 & 3234 & 2779 & 1973 & 4111 & 1643 \\
\hline 1989 & 3323 & 2344 & 7462 & 5752 & 4125 & 2899 & 5142 & 2541 \\
\hline 1990 & 4088 & 2843 & 6054 & 4544 & 3976 & 1569 & 4722 & 2270 \\
\hline 1991 & 3448 & 2340 & 5720 & 4338 & 4281 & 2957 & 4912 & 2462 \\
\hline 1992 & 1607 & 1129 & 4220 & 3091 & 2602 & 1586 & 4069 & 2143 \\
\hline 1993 & 2220 & 1538 & 5502 & 3689 & 2826 & 1834 & 4554 & 2314 \\
\hline 1994 & 3747 & 2554 & 7654 & 5818 & 4098 & 2641 & 3626 & 2006 \\
\hline 1995 & 2546 & 1732 & 4499 & 3365 & 3518 & 2476 & 2797 & 1588 \\
\hline 1996 & 1590 & 1037 & 3818 & 2580 & 2918 & 1784 & 2192 & 1126 \\
\hline 1997 & 1403 & 938 & 3593 & 2321 & 2615 & 1565 & 2274 & 1134 \\
\hline 1998 & 1492 & 876 & 3460 & 2253 & 2572 & 1473 & 2454 & 1156 \\
\hline 1999 & 1488 & 833 & 3198 & 2038 & 2352 & 1335 & 2332 & 1031 \\
\hline 2000 & 1470 & 839 & 3307 & 2086 & 2441 & 1406 & 2351 & 993 \\
\hline 2001 & 1520 & 897 & 3534 & 2289 & 2746 & 1535 & 2625 & 1080 \\
\hline
\end{tabular}

Fonte: FGV 
ANEXO F - Resultados dos testes de auto-correlação de Durbin-Watson, heterocedasticia de White (resíduos) para as regressões da Tabela 2.

\begin{tabular}{|c|c|c|c|c|}
\hline & \multicolumn{2}{|c|}{$\mathrm{d}_{\text {calculado }}$ (Durbin-Watson) } & \multicolumn{2}{|c|}{$\chi_{\text {calculado }}^{2}$ (White) } \\
\hline & & $\begin{array}{l}\text { is explicativas e } 33 \\
\text { rvações }^{* * *} \\
93 \mathrm{~d}_{\mathrm{s}}=1,730\end{array}$ & \multicolumn{2}{|c|}{$\begin{array}{l}\text { Para } 14 \text { graus de liberdade } \\
\chi_{\text {crítico }}^{2}=23,68\end{array}$} \\
\hline \multicolumn{2}{|l|}{$\begin{array}{l}\text { Preço de venda da terra de } \\
\text { cultura de primeira }\end{array}$} & \multicolumn{2}{|l|}{1,31} & 22,26 \\
\hline $\begin{array}{c}\text { Preço de venda da terra de } \\
\text { pastagem }\end{array}$ & & 1,35 & \multicolumn{2}{|c|}{17,28} \\
\hline \multicolumn{5}{|c|}{$\begin{array}{l}\text { Notas: Os critérios para a rejeição ou não de auto-correlação encontram-se na Tabela } 1 \text { do apêndice. A } \\
\text { hipótese nula no teste de heterocedasticia é que os termos de erro são homocedásticos. } \\
{ }^{* *} \text { Nível de significância de } 5 \% \text {. }\end{array}$} \\
\hline \multicolumn{5}{|c|}{ ANEXO G - Matriz de correlação simples das variáveis explicativas da Tabela 2.} \\
\hline & $\mathrm{PC}$ & VCRSUB & LTINF & HIATO \\
\hline $\mathrm{PC}$ & 1,00 & 0,11 & 0,17 & 0,21 \\
\hline VCRSUB & 0,11 & 1,00 & 0,07 & 0,19 \\
\hline LTINF & 0,17 & 0,07 & 1,00 & 0,39 \\
\hline HIATO & 0,21 & 0,19 & 0,39 & 1,00 \\
\hline
\end{tabular}

Fonte: Resultados da pesquisa.

ANEXO H - Resultados dos testes de auto-correlação de Durbin-Watson, heterocedasticia de White (resíduos) para as regressões da Tabela 4.

\begin{tabular}{|c|c|c|c|c|}
\hline & \multicolumn{2}{|c|}{$\mathrm{d}_{\text {calculado }}$ (Durbin-Watson) } & \multicolumn{2}{|c|}{$\chi_{\text {calculado }}^{2}$ (White) } \\
\hline & \multicolumn{2}{|c|}{$\begin{array}{c}\text { Para } 4 \text { variáveis explicativas e } 33 \\
\text { observações } \\
\mathrm{d}_{\mathrm{i}}=1,193 \mathrm{~d}_{\mathrm{s}}=1,730 \\
\end{array}$} & \multicolumn{2}{|c|}{$\begin{array}{c}\text { Para } 13 \text { graus de liberdade } \\
\chi_{\text {crítico }}^{2}{ }^{2 *}=22,36\end{array}$} \\
\hline $\begin{array}{l}\text { Preço de venda da terra de } \\
\text { cultura de primeira }\end{array}$ & \multicolumn{2}{|c|}{1,62} & \multicolumn{2}{|c|}{16,20} \\
\hline $\begin{array}{c}\text { Preço de venda da terra de } \\
\text { pastagem }\end{array}$ & \multicolumn{2}{|c|}{1,41} & \multicolumn{2}{|c|}{16,31} \\
\hline \multicolumn{5}{|c|}{$\begin{array}{l}\text { Fonte: Resultados da pesquisa. } \\
\text { Notas: Os critérios para a rejei } \\
\text { hipótese nula no teste de } \\
{ }^{* *} \text { Nível de significância de } 5 \% \text {. }\end{array}$} \\
\hline \multicolumn{5}{|c|}{ ANEXO I - Matriz de correlação simples das variáveis explicativas da Tabela 4.} \\
\hline & VCRSUB & PC & HIATO & BIN \\
\hline VCRSUB & 1,00 & 0,11 & 0,19 & 0,47 \\
\hline PC & 0,11 & 1,00 & 0,21 & 0,05 \\
\hline HIATO & 0,19 & 0,21 & 1,00 & 0,08 \\
\hline $\mathrm{BIN}$ & 0,47 & 0,05 & 0,08 & 1,00 \\
\hline
\end{tabular}

Fonte: Resultados da pesquisa. 
ANEXO J - Resultados dos testes de auto-correlação de Durbin-Watson, heterocedasticia de White (resíduos) para as regressões da Tabela 6.

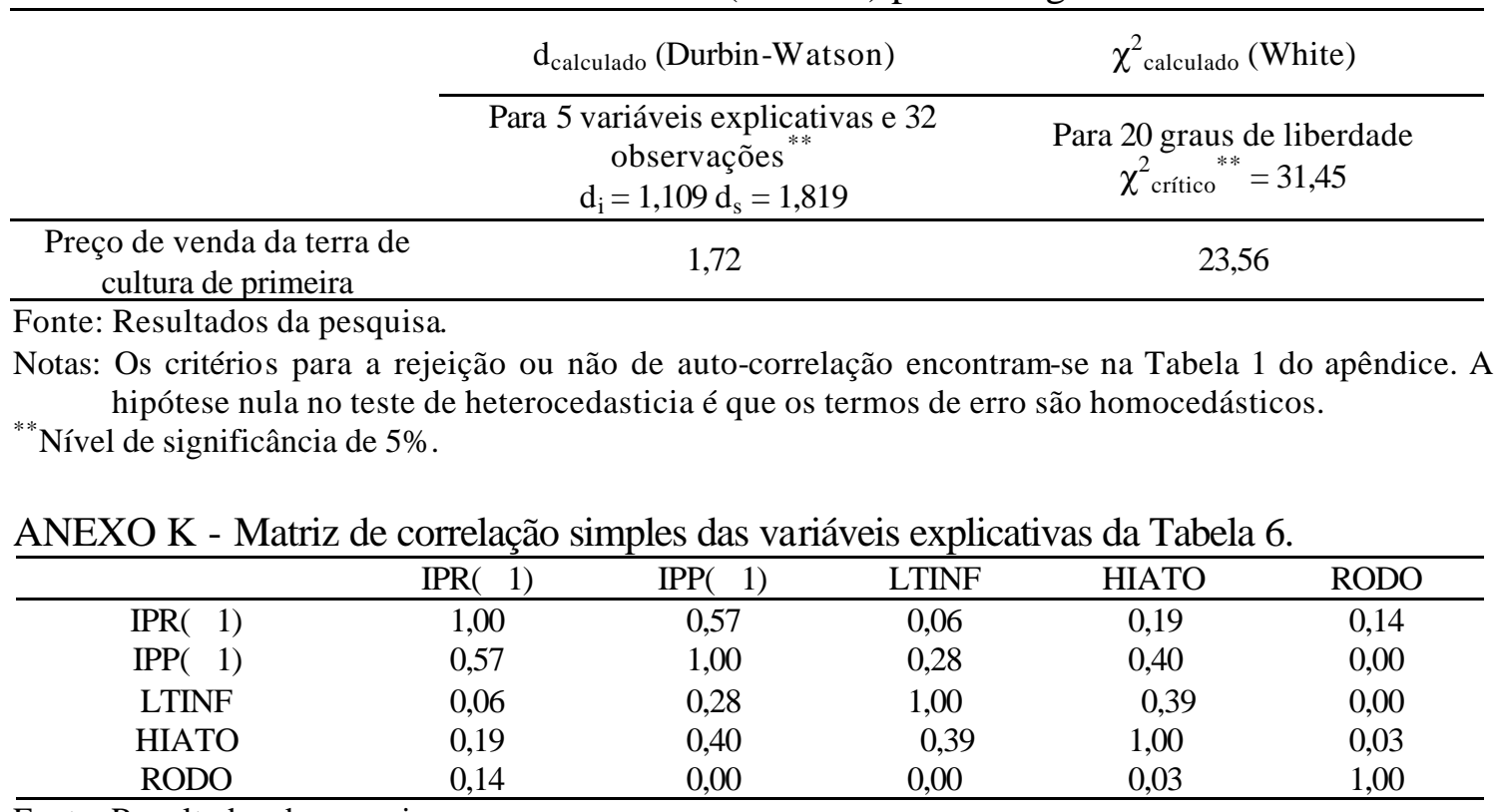

Fonte: Resultados da pesquisa.

ANEXO L - Resultados dos testes de auto-correlação de Durbin-Watson, heterocedasticia de White (resíduos) para as regressões da Tabela 8.

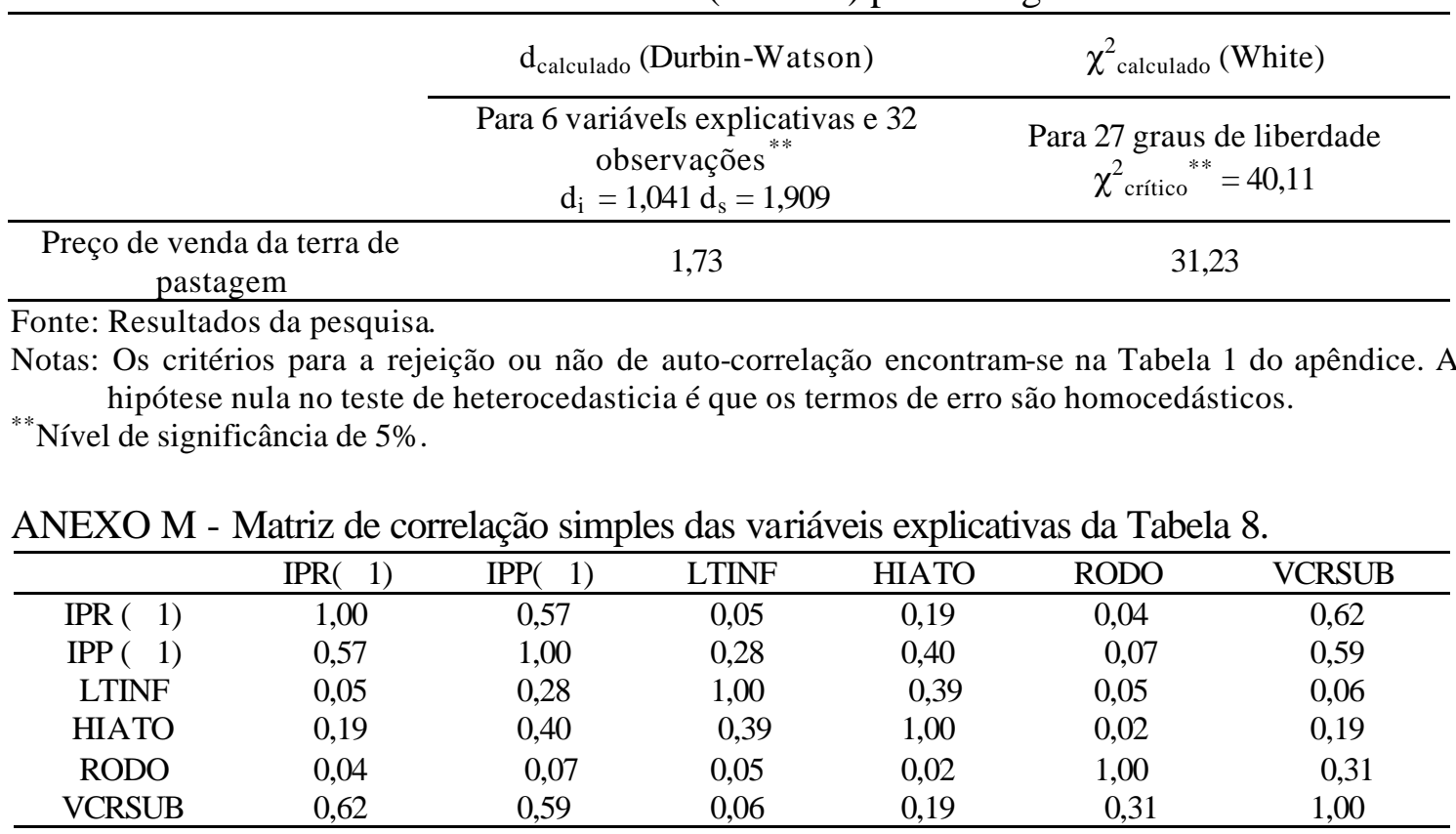

Fonte: Resultados da pesquisa. 
ANEXO N - Resultados dos testes de auto-correlação de Durbin-Watson, heterocedasticia de White (resíduos) para as regressões da Tabela 10.

\begin{tabular}{ccc}
\hline & $\mathrm{d}_{\text {calculado }}$ (Durbin-Watson) & $\chi_{\text {calculado }}^{2}$ (White) \\
\cline { 2 - 3 } & $\begin{array}{c}\text { Para } 4 \text { variáveIs explicativas e 28 } \\
\text { observações } \\
\mathrm{d}_{\mathrm{i} * *}=1,104 \mathrm{~d}_{\mathrm{s}}=1,747\end{array}$ & $\begin{array}{c}\text { Para } 14 \text { graus de liberdade } \\
\chi^{2}{ }_{\text {crítico }}{ }^{* * 23,68}\end{array}$ \\
\hline $\begin{array}{c}\text { Preço de venda da terra de } \\
\text { pastagem }\end{array}$ & 1,28 & 20,56 \\
\hline
\end{tabular}

Fonte: Resultados da pesquisa.

Notas: Os critérios para a rejeição ou não de auto-correlação encontram-se na Tabela 1 do apêndice. A hipótese nula no teste de heterocedasticia é que os termos de erro são homocedásticos.

**Nível de significância de 5\%.

ANEXO O - Matriz de correlação simples das variáveis explicativas da Tabela 10.

\begin{tabular}{ccccc}
\hline & PC & TJ & HIATO & LTINF \\
\hline PC & 1,00 & 0,14 & 0,21 & 0,25 \\
TJ & 0,14 & 1,00 & 0,20 & 0,12 \\
HIATO & 0,21 & 0,20 & 1,00 & 0,42 \\
LTINF & 0,25 & 0,12 & 0,42 & 1,00 \\
\hline
\end{tabular}

Fonte: Resultados da pesquisa.

ANEXO P - Resultados dos testes de auto-correlação de Durbin-Watson, heterocedasticia de White (resíduos) para as regressões da Tabela 12.

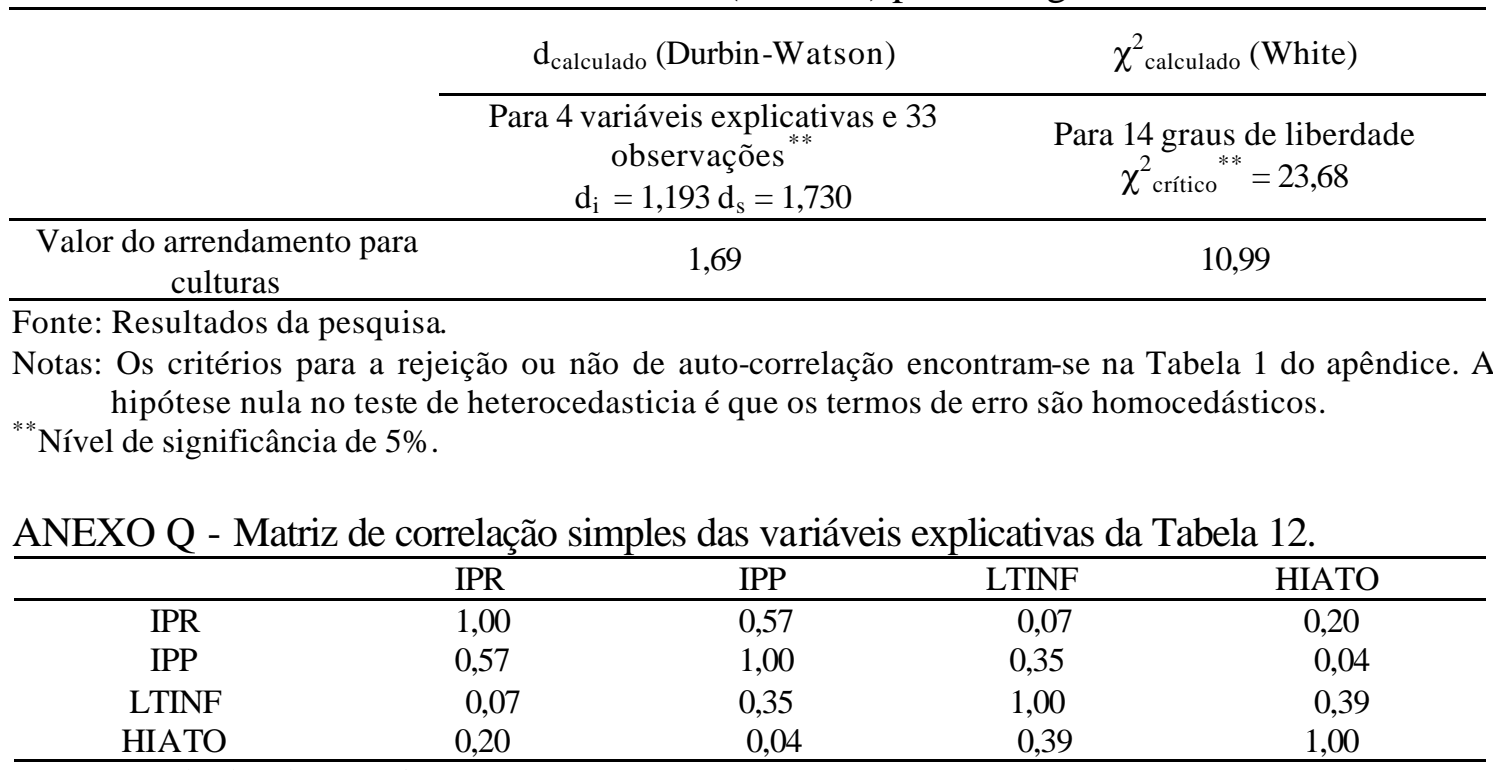

Fonte: Resultados da pesquisa. 
ANEXO R - Resultados dos testes de auto-correlação de Durbin-Watson, heterocedasticia de White (resíduos) para as regressões da Tabela 14.

\begin{tabular}{ccc}
\hline & $\mathrm{d}_{\text {calculado }}$ (Durbin-Watson) & $\chi_{\text {calculado }}^{2}$ (White) \\
\cline { 2 - 3 } & $\begin{array}{c}\text { Para 4 variáveis explicativas e 33 } \\
\text { observações } \\
\mathrm{d}_{\mathrm{i}}=1,193 \mathrm{~d}_{\mathrm{s}}=1,730\end{array}$ & $\begin{array}{c}\text { Para } 13 \text { graus de liberdade } \\
\chi^{2} \text { crítico }^{* *}=22,36\end{array}$ \\
\hline $\begin{array}{c}\text { Valor do arrendamento para } \\
\text { culturas }\end{array}$ & 1,77 & 7,46 \\
\hline
\end{tabular}

Fonte: Resultados da pesquisa.

Notas: Os critérios para a rejeição ou não de auto-correlação encontram-se na Tabela 1 do apêndice. A hipótese nula no teste de heterocedasticia é que os termos de erro são homocedásticos.

***ível de significância de 5\%.

ANEXO S - Matriz de correlação simples das variáveis explicativas da Tabela 14.

\begin{tabular}{ccccc}
\hline & IPR & IPP & BIN & HIATO \\
\hline IPR & 1,00 & 0,57 & 0,51 & 0,20 \\
IPP & 0,57 & 1,00 & 0,64 & 0,04 \\
BIN & 0,51 & 0,64 & 1,00 & 0,08 \\
HIATO & 0,20 & 0,04 & 0,08 & 1,00 \\
\hline
\end{tabular}

Fonte: Resultados da pesquisa.

ANEXO $\mathrm{T}$ - Resultados dos testes de auto-correlação de Durbin-Watson, heterocedasticia de White (resíduos) para as regressões da Tabela 16.

\begin{tabular}{|c|c|c|c|c|}
\hline & \multicolumn{2}{|c|}{$\mathrm{d}_{\text {calculado }}$ (Durbin-Watson) } & \multicolumn{2}{|c|}{$\chi_{\text {calculado }}^{2}$ (White) } \\
\hline & & $\begin{array}{l}\text { S explicativas e } 28 \\
\text { vações } \\
4 \mathrm{~d}_{\mathrm{s}}=1,747\end{array}$ & \multicolumn{2}{|c|}{$\begin{array}{l}\text { Para } 14 \text { graus de liberdade } \\
\quad \chi_{\text {crítico }}^{2}=23,68\end{array}$} \\
\hline $\begin{array}{c}\text { Valor do arrendamento para } \\
\text { culturas }\end{array}$ & \multicolumn{2}{|c|}{1,26} & \multicolumn{2}{|c|}{20,51} \\
\hline \multicolumn{5}{|c|}{$\begin{array}{l}\text { Notas: Os critérios para a rejeição ou não de auto-correlação encontram-se na Tabela } 1 \text { do apêndic } \\
\text { hipótese nula no teste de heterocedasticia é que os termos de erro são homocedásticos. } \\
{ }^{* *} \text { Nível de significância de } 5 \% \text {. }\end{array}$} \\
\hline \multicolumn{5}{|c|}{ ANEXO U - Matriz de correlação simples das variáveis explicativas da Tabela 16.} \\
\hline & IP & LTINF & HIATO & TJ \\
\hline IP & 1,00 & 0,34 & 0,24 & 0,30 \\
\hline LTINF & 0,34 & 1,00 & 0,42 & 0,12 \\
\hline HIATO & 0,24 & 0,42 & 1,00 & 0,20 \\
\hline $\mathrm{TJ}$ & 0,30 & 0,12 & 0,20 & 1,00 \\
\hline
\end{tabular}

Fonte: Resultados da pesquisa. 
ANEXO V - Resultados dos testes de auto-correlação de Durbin-Watson, heterocedasticia de White (resíduos) para as regressões da Tabela 18.

\begin{tabular}{|c|c|c|}
\hline & $\mathrm{d}_{\text {calculado }}$ (Durbin-Watson) & $\chi_{\text {calculado }}^{2}$ (White) \\
\hline & $\begin{array}{c}\text { Para } 2 \text { variáveis explicativas e } 33 \\
\text { observações }{ }^{* * *} \\
\mathrm{~d}_{\mathrm{i}}=1,321 \mathrm{~d}_{\mathrm{s}}=1,577\end{array}$ & $\begin{array}{c}\text { Para } 4 \text { graus de liberdade } \\
\chi_{\text {crítico }}^{2}=9,49\end{array}$ \\
\hline Valor do aluguel de pasto & 1,70 & 3,20 \\
\hline \multicolumn{3}{|c|}{$\begin{array}{l}\text { Fonte: Resultados da pesquisa. } \\
\text { Notas: Os critérios para a rejeição ou não de auto-correlação encontram-se na Tabela } 1 \text { do apêndice. } \\
\text { hipótese nula no teste de heterocedasticia é que os termos de erro são homocedásticos. } \\
{ }^{* *} \text { Nível de significância de } 5 \% \text {. }\end{array}$} \\
\hline \multicolumn{3}{|c|}{ ANEXO W - Matriz de correlação simples das variáveis explicativas da Tabela 18.} \\
\hline & IP & BIN \\
\hline IP & 1,00 & 0,09 \\
\hline BIN & 0,09 & 1,00 \\
\hline
\end{tabular}

Fonte: Resultados da pesquisa.

ANEXO X - Resultados dos testes de auto-correlação de Durbin-Watson, heterocedasticia de White (resíduos) para as regressões da Tabela 20.

\begin{tabular}{|c|c|c|}
\hline & $\mathrm{d}_{\text {calculado }}$ (Durbin-Watson) & $\chi_{\text {calculado }}^{2}$ (White) \\
\hline & $\begin{array}{c}\text { Para } 3 \text { variáveis explicativas e } 33 \\
\text { observações } \\
\mathrm{d}_{\mathrm{i}}=1,258 \mathrm{~d}_{\mathrm{s}}=1,651 \\
\end{array}$ & $\begin{array}{c}\text { Para } 9 \text { graus de liberdade } \\
\chi_{\text {crítico }}^{2}=16,92\end{array}$ \\
\hline Valor do aluguel de pasto & 1,34 & 4,42 \\
\hline \multicolumn{3}{|c|}{$\begin{array}{l}\text { Fonte: Resultados da pesquisa. } \\
\text { Notas: Os critérios para a rejeição ou não de auto-correlação encontram-se na Tabela } 1 \text { do apêndice. A } \\
\quad \text { hipótese nula no teste de heterocedasticia é que os termos de erro são homocedásticos. } \\
{ }^{* *} \text { Nível de significância de } 5 \% \text {. }\end{array}$} \\
\hline \multicolumn{3}{|c|}{ ANEXO Y - Matriz de correlação simples das variáveis explicativas da Tabela 20.} \\
\hline & LTINF & HIATO \\
\hline IP & 1,00 & 0,23 \\
\hline LTINF & 0,38 & 0,39 \\
\hline HIATO & 0,23 & 1,00 \\
\hline
\end{tabular}

Fonte: Resultados da pesquisa. 
ANEXO Z - Resultados dos testes de auto-correlação de Durbin-Watson, heterocedasticia de White (resíduos) para as regressões da Tabela 22.

\begin{tabular}{|c|c|c|}
\hline & $\mathrm{d}_{\text {calculado }}$ (Durbin-Watson) & $\chi_{\text {calculado }}^{2}$ (White) \\
\hline & $\begin{array}{c}\text { Para } 3 \text { variáveis explicativas e } 33 \\
\text { observações } \\
\mathrm{d}_{\mathrm{i}}=1,258 \mathrm{~d}_{\mathrm{s}}=1,651 \\
\end{array}$ & $\begin{array}{c}\text { Para } 9 \text { graus de liberdade } \\
\chi_{\text {crítico }}^{2}{ }^{2 *}=16,92\end{array}$ \\
\hline Valor do aluguel de pasto & 1,30 & 10,50 \\
\hline \multicolumn{3}{|c|}{$\begin{array}{l}\text { Fonte: Resultados da pesquisa. } \\
\text { Notas: Os critérios para a rejeição ou não de auto-correlação encontram-se na Tabela } 1 \text { do apêndice. } \\
\text { hipótese nula no teste de heterocedasticia é que os termos de erro são homocedásticos. } \\
{ }^{* *} \text { Nível de significância de } 5 \% \text {. }\end{array}$} \\
\hline \multicolumn{3}{|c|}{ ANEXO AA - Matriz de correlação simples das variáveis explicativas da Tabela 22.} \\
\hline & VCRSUB & LTINF \\
\hline IP & 0,47 & 0,38 \\
\hline VCRSUB & 1,00 & 0,07 \\
\hline LTINF & 0,38 & 1,00 \\
\hline
\end{tabular}

Fonte: Resultados da pesquisa.

ANEXO BB - Resultados dos testes de auto-correlação de Durbin-Watson, heterocedasticia de White (resíduos) para as regressões da Tabela 24.

\begin{tabular}{|c|c|c|}
\hline & $\mathrm{d}_{\text {calculado }}$ (Durbin-Watson) & $\chi_{\text {calculado }}^{2}$ (White) \\
\hline & $\begin{array}{c}\text { Para } 3 \text { variáveis explicativas e } 28 \\
\text { observações } \\
\mathrm{d}_{\mathrm{i}}=1,181 \mathrm{~d}_{\mathrm{s}}=1,650\end{array}$ & $\begin{array}{l}\text { Para } 9 \text { graus de liberdade } \\
\chi^{2}{ }_{\text {crítico }}^{* *}=16,92\end{array}$ \\
\hline Valor do aluguel de pasto & 1,62 & 8,20 \\
\hline \multicolumn{3}{|c|}{$\begin{array}{l}\text { Notas: Os critérios para a rejeição ou não de auto-correlação encontram-se na Tabela } 1 \text { do apêndice. } \\
\text { hipótese nula no teste de heterocedasticia é que os termos de erro são homocedásticos. } \\
\text { *** Nível de significância de } 5 \% \text {. }\end{array}$} \\
\hline \multicolumn{3}{|c|}{ ANEXO CC - Matriz de correlação simples das variáveis explicativas da Tabela 24.} \\
\hline & LTINF & TJ \\
\hline IP & 1,00 & 0,30 \\
\hline LTINF & 0,34 & 0,12 \\
\hline $\mathrm{TJ}$ & 0,30 & 1,00 \\
\hline
\end{tabular}

Fonte: Resultados da pesquisa. 
ANEXO DD - Matriz de correlação simples de todas as variáveis explicativas (excluindo a taxa de juro real).

\begin{tabular}{ccccccccccc}
\hline & BIN & BINR & HIATO & LTINF & IP & IPP & IPR & PC & RODO & VCRSUB \\
\hline BIN & 1 & 0,22 & 0,08 & 0,72 & 0,09 & 0,64 & 0,51 & 0,05 & 0,06 & 0,47 \\
BINR & 0,22 & 1 & 0,07 & 0,10 & 0,63 & 0,08 & 0,55 & 0,35 & 0,67 & 0,22 \\
HIATO & 0,08 & 0,07 & 1 & 0,39 & 0,23 & 0,04 & 0,20 & 0,21 & 0,02 & 0,19 \\
LTINF & 0,72 & 0,10 & 0,39 & 1 & 0,38 & 0,35 & 0,07 & 0,17 & 0,09 & 0,07 \\
IP & 0,09 & 0,63 & 0,23 & 0,38 & 1 & 0,04 & 0,79 & 0,52 & 0,10 & 0,47 \\
IPP & 0,64 & 0,08 & 0,04 & 0,35 & 0,04 & 1 & 0,57 & 0,03 & 0,05 & 0,41 \\
IPR & 0,51 & 0,55 & 0,20 & 0,07 & 0,79 & 0,57 & 1 & 0,42 & 0,05 & 0,69 \\
PC & 0,05 & 0,35 & 0,21 & 0,17 & 0,52 & 0,03 & 0,42 & 1 & 0,37 & 0,11 \\
RODO & 0,06 & 0,67 & 0,02 & 0,09 & 0,10 & 0,05 & 0,05 & 0,37 & 1 & 0,27 \\
VCRSUB & 0,47 & 0,22 & 0,19 & 0,07 & 0,47 & 0,41 & 0,69 & 0,11 & 0,27 & 1 \\
\hline
\end{tabular}

Fonte: Resultados da pesquisa.

ANEXO EE - Matriz de correlação simples de todas as variáveis explicativas (incluindo a taxa de juro real).

\begin{tabular}{cccccccccccc}
\hline & BIN & BINR & HIATO & LTINF & TJ & IP & IPP & IPR & PC & RODO & VCRSUB \\
\hline BIN & 1,00 & 0,20 & 0,15 & 0,73 & 0,46 & 0,19 & 0,59 & 0,52 & 0,07 & 0,13 & 0,44 \\
BINR & 0,20 & 1,00 & 0,07 & 0,15 & 0,05 & 0,68 & 0,04 & 0,56 & 0,35 & 0,69 & 0,20 \\
HIATO & 0,15 & 0,07 & 1,00 & 0,43 & 0,20 & 0,24 & 0,07 & 0,19 & 0,21 & 0,02 & 0,19 \\
LTINF & 0,73 & 0,15 & 0,43 & 1,00 & 0,12 & 0,34 & 0,29 & 0,10 & 0,25 & 0,06 & 0,02 \\
TJ & 0,46 & 0,05 & 0,20 & 0,12 & 1,00 & 0,30 & 0,47 & 0,55 & 0,14 & 0,32 & 0,57 \\
IP & 0,19 & 0,68 & 0,24 & 0,34 & 0,30 & 1,00 & 0,01 & 0,82 & 0,58 & 0,23 & 0,56 \\
IPP & 0,59 & 0,04 & 0,07 & 0,29 & 0,47 & 0,01 & 1,00 & 0,56 & 0,04 & 0,21 & 0,37 \\
IPR & 0,52 & 0,56 & 0,19 & 0,10 & 0,55 & 0,82 & 0,56 & 1,00 & 0,40 & 0,03 & 0,72 \\
PC & 0,07 & 0,35 & 0,21 & 0,25 & 0,14 & 0,58 & 0,04 & 0,40 & 1,00 & 0,34 & 0,07 \\
RODO & 0,13 & 0,69 & 0,02 & 0,06 & 0,32 & 0,23 & 0,21 & 0,03 & 0,34 & 1,00 & 0,44 \\
VCRSUB & 0,44 & 0,20 & 0,19 & 0,02 & 0,57 & 0,56 & 0,37 & 0,72 & 0,07 & 0,44 & 1,00 \\
\hline
\end{tabular}

Fonte: Resultados da pesquisa.

ANEXO FF - Matriz de correlação simples de todas as variáveis explicativas, estando os índices de preços recebidos e de preços pagos pelos produtores defasados em um período (excluindo a taxa de juro real).

\begin{tabular}{ccccccccccc}
\hline & BIN & BINR & HIATO & LTINF & IP & IPP( 1) & IPR( 1$)$ & PC & RODO & VCRSUB \\
\hline BIN & 1,00 & 0,22 & $-0,08$ & 0,71 & 0,11 & 0,60 & 0,56 & $-0,01$ & $-0,01$ & 0,46 \\
BINR & 0,22 & 1,00 & 0,07 & $-0,11$ & 0,63 & 0,09 & 0,50 & 0,35 & 0,68 & 0,22 \\
HIATO & $-0,08$ & 0,07 & 1,00 & $-0,39$ & 0,23 & 0,40 & 0,19 & 0,22 & 0,02 & 0,19 \\
LTINF & 0,71 & $-0,11$ & $-0,39$ & 1,00 & $-0,38$ & 0,28 & 0,06 & $-0,21$ & 0,05 & 0,06 \\
IP & 0,11 & 0,63 & 0,23 & $-0,38$ & 1,00 & 0,30 & 0,54 & 0,55 & 0,12 & 0,47 \\
IPP( 1) & 0,60 & 0,09 & 0,40 & 0,28 & 0,30 & 1,00 & 0,57 & 0,23 & $-0,07$ & 0,59 \\
IPR( 1) & 0,56 & 0,50 & 0,19 & 0,06 & 0,54 & 0,57 & 1,00 & 0,36 & 0,04 & 0,62 \\
PC & $-0,01$ & 0,35 & 0,22 & $-0,21$ & 0,55 & 0,23 & 0,36 & 1,00 & 0,33 & 0,09 \\
RODO & $-0,01$ & 0,68 & 0,02 & 0,05 & 0,12 & $-0,07$ & 0,04 & 0,33 & 1,00 & $-0,31$ \\
VCRSUB & 0,46 & 0,22 & 0,19 & 0,06 & 0,47 & 0,59 & 0,62 & 0,09 & $-0,31$ & 1,00 \\
\hline
\end{tabular}

Fonte: Resultados da pesquisa. 


\section{REFERÊNCIAS BIBLIOGRÁFICAS}

AGROANALYSIS retrospecto $1977-1^{\underline{0}}$ semestre. Rio de Janeiro, Grupo de Informação Agrícola, 1977. 198p.

BANCO CENTRAL DO BRASIL. Crédito rural: dados estatísticos. Rio de Janeiro, 1969-1985.

BANCO CENTRAL DO BRASIL. Anuário estatístico do crédito rural. Brasília, 1986-2001.

BACHA, C.J.C. A determinação do preço de venda e de aluguel da terra na agricultura. Estudos Econômicos, v.19, n.3, p.443-456, 1989.

BRANDÃO, A.S.P. O preço da terra no Brasil: verificação de algumas hipóteses. Rio de Janeiro: Fundação Getúlio Vargas, 1986. 86p. (Ensaios Econômicos da EPGE, 79)

BRANDÃO, A.S.P.; REZENDE, G.C. The behaviour of land prices and land rents in Brazil. In: AGRICULTURE AND GOVERNMENT IN AN INTERDEPENDENT WORLD, Buenos Aires, 1989. Anais. Buenos Aires: IAAE, 1989. p.717-727.

BRANDÃO, A.S.P. Mercado de terra e estrutura fundiária. In: BRANDÃO, A.S.P. Os principais problemas da agricultura brasileira: análise e sugestões. 2.ed. Rio de Janeiro: IPEA, 1992. p.139-177. 
CAMARGO, A.M.M.P.; FERREIRA, C.R.R.P.T. Evolução do preço da terra agrícola no Brasil, 1966-1986. Agricultura em São Paulo, v.36, n.1, p.45-71, 1989.

CASTRO, P.R. Organização fundiária e desenvolvimento: uma contribuição ao debate. Rio de Janeiro: Câmara de Estudos e Debates Econômicos e Sociais CEDES, 1981.129p.

CHRYST, W.E. Land values and agricultural income: a paradox ? Journal of Farm Economics, v.47, n.5, p.1265-1277, dez.1965.

DIAS, G.L.S; VIEIRA, C.A.; AMARAL, C.M. Comportamento do mercado de terras no Brasil. Santiago de Chile: CEPAL, 2001. 83p. (Desarrollo productivo, 91)

DIAZ, M.D.M. Problemas econométricos no modelo linear geral. In: VASCONCELLOS, M.A.S; ALVES, D. Manual de econometria: nível intermediário. São Paulo: Atlas, 2000. cap.5, p.105-137: problemas econométricos no modelo linear geral.

DIAZ, M.D.M. Multicolinearidade. In: VASCONCELLOS, M.A.S; ALVES, D. Manual de econometria: nível intermediário. São Paulo: Atlas, 2000. cap.6, p.138145: multicolinearidade.

DICKEY, D.A.; FULLER, W.A. Distribution of the estimators for autoregressive time series with unit root. Journal of the American Statistical Association, v.74, n.366, p.427-431, June 1979.

DICKEY, D.A.; FULLER, W.A. Likelihood ratio statistics for autoregressive time series with a unit root. Econometrica, v.49, n.4, p.1057-1072, July 1981.

DOLL, J.P.; WIDDOWS, R.; VELDE, P.D. The value of agriculture land in the United States: a report on research. Agriculture Economics Research, v.35, n.2, p.39-44, Apr.1983. 
EGLER, C.A.G. Preço da terra, taxa de juro e acumulação financeira no Brasil. Revista de Economia Política, v.5, n.1, p.112-135, jan./mar. 1985.

ENGLE, R.F.; GRANGER, C.W.J. Cointegration and error correction: representation, estimation, and testing. Econometrica, v.55, n.2, p.251-276, Mar. 1987.

ENDERS, W. Applied econometric time series. 1.ed. New York: John Wiley \& Sons, 1995. cap.4, p.211-251: testing for trends and unit roots.

FERREIRA, C.R.P.T; CAMARGO, A.M.M.P. Arrendamento da terra agrícola no Brasil, 1969-1986. Agricultura em São Paulo, v.36, n.1, p.1-16, 1989.

FERREIRA FILHO, J.B.S. Os desafios da estabilização econômica para a agricultura brasileira (The Threats of Economic Stabilization for the Brazilian Agriculture). In: GOMES, M.F.M; COSTA, F.A. (Des) equilíbrio econômico e agronegócio. Viçosa: UFV, DER, 1999. 287p. cap.3, p.431-450.

FRANCA, T.J.F. O certificado de mercadoria com emissão garantida (CM-G) como fonte alternativa de financiamento para o setor agropecuário. Piracicaba, 1996. 145p. Dissertação (M.S.) - Escola Superior de Agricultura "Luiz de Queiroz", Universidade de São Paulo.

FUNDAÇÃO GETÚLIO VARGAS. Série de preços da terra de lavouras e pastagens para os estados de Goiás, Mato Grosso, Espírito Santo, Rio de Janeiro, Paraná, Santa Catarina e Rio Grande do Sul. http://www.fgvdados.fgv.br (27 jan. 2003)

FULLER, W.A. Introduction to statistical time series. New York: John Wiley, 1976. $424 \mathrm{p}$.

FUNDAÇÃO SISTEMA ESTADUAL DE ANÁLISE DE DADOS. Anuário estatístico do estado de São Paulo, 1994. São Paulo: SEADE, 1995. 
FUNDAÇÃO SISTEMA ESTADUAL DE ANÁLISE DE DADOS. Participação do estado de São Paulo no valor adicionado bruto do Brasil segundo setores de atividade econômica. http://www.seade.gov.br (20 ago. 2002)

GRUPO DE ESTUDOS PARA INTEGRAÇÃO DA POLÍTICA DE TRANSPORTES. Anuário estatístico dos transportes. Rio de Janeiro: GEIPOT, 1970-1997.

GRUPO DE ESTUDOS PARA INTEGRAÇÃO DA POLÍTICA DE TRANSPORTES. Anuário estatístico do GEIPOT. Extensão total das rodovias pavimentadas e não pavimentadas: 1996-00. http://www.transportes.gov.br/bit/inrodo.htm (20 jul. 2002)

GUJARATTI, D. Econometria básica. 3.ed. São Paulo: Makron Books, 2000. cap.21, p.715-736: econometria de séries temporais I.

HELFAND, S.M.; REZENDE, G.C. A agricultura brasileira nos anos 1990: o impacto das reformas de políticas. In: GASQUES, J.G.; CONCEIÇÃO, J.C.P.R. Transformações da agricultura e políticas públicas. Brasília: IPEA, 2001. cap.6, p.249-251.

HOFFMANN, R. Estatística para economistas. 3.ed. São Paulo: Pioneira, 1998. cap.17, p.314-317: números-índices.

INSTITUTO BRASILEIRO DE GEOGRAFIA E ESTATÍSTICA. Participação das grandes regiões e unidades da federação no produto interno bruto do Brasil, a $\begin{array}{llllll}\text { preço de mercado corrente: } & 1996 & - & 1999 .\end{array}$ http://www1.ibge.gov.br/home/estatistica/economia/contasregionais/Tabela5.shtm. (15 jun. 2003)

INSTITUTO DE ECONOMIA AGRÍCOLA. Desenvolvimento da agricultura paulista. São Paulo: IEA, 1972. 319p.

INSTITUTO DE ECONOMIA AGRÍCOLA. Anuário estatístico da agricultura. São Paulo: IEA, 1989-2001. 
INSTITUTO DE ECONOMIA AGRÍCOLA. Estatísticas de preços agrícolas no estado de São Paulo. São Paulo: IEA, 1990a. n.3.

INSTITUTO DE ECONOMIA AGRÍCOLA. Estatísticas de produção agrícola no estado de São Paulo. São Paulo: IEA, 1990b.

INSTITUTO DE ECONOMIA AGRÍCOLA. Estatísticas do mercado de terras agrícolas no estado de São Paulo. São Paulo, fev. 1993.

INSTITUTO DE PESQUISA ECONÔMICA APLICADA. IGP-DI - geral: índice/ago $1994=100$. http://www.ipeadata.gov.br (20 jun. 2002)

JOHANSEN, S. Statistical analysis of cointegration vectors. Journal of Economics Dynamics and Control, v.12, n.2/3, p.231-254, 1988.

JOHANSEN, S.; JUSELIUS, K. Maximum likelihood estimation and inference on cointegration: with applications to the demand for money. Oxford Bulletin of Economics and Statistics, v.52, n.2, p.169-210, 1990.

JOHNSON, D.G. The nature of the supply function for agricultural products. American Economic Review, v.40, n.4, p.539-64, 1950.

MONTEIRO, M.J.C. Preços de terra e plano de estabilização. Agroanalysis, v.15, n.12, p.24-26, dez. 1995.

OLIVEIRA, J.T.; COSTA, I.D.N. Evolução recente do preço de terra no Brasil: 19661974. Revista de Economia e Sociologia Rural, v.15, n.3, p.259-276, 1977.

PINHEIRO, F.A. A renda e o preço da terra: uma contribuição à análise da questão agrária brasileira. Piracicaba, 1980. 277p. Tese (Livre-Docência) - Escola Superior de Agricultura "Luiz de Queiroz", Universidade de São Paulo. 
PINHEIRO, F.A.; REYDON, B.P. O preço da terra e a questão agrária: algumas evidências empíricas relevantes. Revista de Economia Rural, v.19, n.1, p.5-15, jan./mar. 1981.

RANGEL, I. Questão agrária, industrialização e crise urbana no Brasil. 1.ed. Porto Alegre: Editora da Universidade Federal do Rio Grande do Sul, 2000. 266p.

REINSEL, R.D.; REINSEL, E.I. The economics of asset values and current income in farming. American Journal of Agriculture Economics. v.61, n.5, p.93-97, dez. 1979.

REYDON, B.P. A formação do mercado de terras: algumas questões teóricas. In: CONGRESSO BRASILEIRO DE ECONOMIA E SOCIOLOGIA RURAL, 27., Piracicaba, SP, 1989. Anais. Brasília: SOBER, 1989. p.416-425.

REYDON, B.P.; PLATA, L.A. Intervenção estatal no mercado de terras: a experiência recente no Brasil. Campinas: UNICAMP, NEA/IE, 2000. 170p. (Estudos NEAD, 3)

REZENDE, G.C. Crédito rural subsidiado e o preço da terra no Brasil. Estudos Econômicos, v.12, n.2, p.117-137, ago. 1982a.

REZENDE, G.C. Política agrícola, preço da terra e estrutura agrária. Revista de Economia Rural. Brasília, v.20, n.1, p.73-100, 1982b.

REZENDE, G.C. A agricultura e a reforma do crédito rural. Revista Brasileira de Economia, v.39, n.2, p.185-206, abr./jun. 1985.

REZENDE, G. C. Ocupação agrícola e estrutura agrária no cerrado: o papel do preço da terra, dos recursos naturais e da tecnologia (compact disc). In: CONGRESSO BRASILEIRO DE ECONOMIA E SOCIOLOGIA RURAL, 40., Passo Fundo, 2002. Anais. Brasília: Universidade Passo Fundo/SOBER, 2002. 
ROMEIRO, A.; REYDON, B.P. O mercado de terras. Estudos de Política Agrícola, n.13, p.204, mar. 1994.

SAYAD, J. Planejamento, crédito e distribuição de renda. Estudos Econômicos, v.7, n.1, p.9-34, jan./abr. 1977a.

SAYAD, J. Preço da terra e mercados financeiros. Pesquisa e Planejamento Econômico, v.7, n.3, p.623-662, dez. 1977b.

SAYAD, J. Especulação em terras rurais, efeitos sobre a produção agrícola e o mvo ITR. Pesquisa e Planejamento Econômico, v.12, n.1, p.87-108, abr. 1982.

SHIROTA, R. Crédito rural no Brasil: subsídio, distribuição e fatores associados à oferta. Piracicaba, 1988. 229p. Dissertação (M.S.) - Escola Superior de Agricultura "Luiz de Queiroz", Universidade de São Paulo.

TWEETEN, L. Farm policy analysis. Bowlder: Westview Press, 1989. cap.1, p.1-34: Farm characteristics and problems. 
APÊNDICE 
APÊNDICE 1 - Teste $d$ de Durbin-Watson: regras de decisão.

Hipótese nula

Ausência de auto-correlação positiva

Ausência de auto-correlação positiva

Ausência de correlação negativa

Ausência de correlação negativa

Ausência de auto-correlação, positiva ou negativa

Fonte: Gujaratti (2000)
Decisão

Rejeitar

Nenhuma decisão

Rejeitar

Nenhuma decisão

Não rejeitar
$\mathrm{Se}$

$0<d<d_{l}$

$d_{1} \leq d \leq d_{s}$

$4-d_{l}<d<4$

$4-d_{s} \leq d \leq 4-d_{1}$

$d_{s}<d<4-d_{s}$ 